UNIVERSIDADE DE SÃO PAULO

INSTITUTO DE RELAÇÕES INTERNACIONAIS

PROGRAMA DE PÓS-GRADUAÇÃO EM RELAÇÕES INTERNACIONAIS

CAMILA BIBIANA FREITAS BARALDI

\author{
MIGRAÇÕES INTERNACIONAIS, DIREITOS \\ HUMANOS E CIDADANIA SUL-AMERICANA: O PRISMA \\ DO BRASIL E DA INTEGRAÇÃO SUL-AMERICANA
}

São Paulo

2014 


\section{MIGRAÇÕES INTERNACIONAIS, DIREITOS \\ HUMANOS E CIDADANIA SUL-AMERICANA: O PRISMA DO BRASIL E DA INTEGRAÇÃO SUL-AMERICANA}

CAMILA BIBIANA FREITAS BARALDI

Tese apresentada ao Programa de Pós-Graduação em Relações Internacionais do Instituto de Relações Internacionais da Universidade de São Paulo, para a obtenção do título de Doutor em Ciências Programa de Pós-Graduação em Relações em Internacionais - Versão Final

Orientadora: Profa. Dra. Deisy de Freitas Lima Ventura.

Durante o desenvolvimento deste trabalho, a autora recebeu auxílio financeiro da FAPESP Fundação de Amparo à Pesquisa do Estado de São Paulo

São Paulo

2014 
BARALDI, Camila Bibiana Freitas. Migrações Internacionais, Direitos Humanos e Cidadania Sul-Americana: o prisma do Brasil e da Integração Sul-americana. Tese apresentada ao Programa de Pós-Graduação em Relações Internacionais do Instituto de Relações Internacionais da Universidade de São Paulo, 2014.

Aprovado em: 08/08/2014

Banca Examinadora:

Deisy de Freitas Lima Ventura (Presidente) - IRI/USP

André de Carvalho Ramos (membro titular) - FD/USP

Flavia Ines Schilling (membro titular) - FE/USP

Helion Póvoa Neto (membro titular) - UFRJ - Externo

Rossana Rocha Reis (membro titular) - FFLCH/USP 
Aos meus pais: compreensão e carinho Ao Pedro: amor, paz e crescimento 


\section{Agradecimentos}

Uma tese de doutorado é um trabalho com algumas características contraditórias: é extremamente solitário e precisa contar com a colaboração de muitas instituições e pessoas, no campo profissional e pessoal. Sendo assim, registro de forma singela, neste espaço, um agradecimento sincero a todos aqueles que contribuíram para que este percurso se realizasse e este resultado pudesse se concretizar.

À minha orientadora, Prof. Deisy Ventura, agradeço o estímulo e o incentivo permanentes ao meu desenvolvimento intelectual; além da generosidade acadêmica, que é uma de suas maiores qualidades;

À Universidade de São Paulo e à Fundação de Amparo à Pesquisa do Estado de São Paulo - FAPESP agradeço a possibilidade do desenvolvimento dessa pesquisa, sublinhando a importância do ensino e do financiamento público da pesquisa no Brasil, sem os quais, eu certamente não poderia ter chegado a este resultado.

Ao Centro de Direitos Humanos e Cidadania do Imigrante - CDHIC, ao Espaço Sem Fronteiras - ESF e ao Paulo Illes, agradeço a vivência concreta junto aos imigrantes e suas lutas, experiência que delineou os contornos desta tese.

Ao International Migration Institute (IMI) da University of Oxford agradeço a recepção agradável e o ambiente intelectualmente estimulante que me permitiu desenvolver grande parte da pesquisa teórica para esta tese. Perceber que pesquisa de alto nível também se faz com tranquilidade também foi reconfortante.

À Coordenação de Políticas para Migrantes (CPMig) da Prefeitura Municipal de São Paulo agradeço o aprendizado quotidiano que vem me proporcionando em diversos campos. Viver a experiência inovadora de políticas locais para migrantes no Brasil me traz segurança sobre o conhecimento que construí em todos estes anos de estudos e pesquisas.

À equipe da CPMig: Paulo Illes, Guilherme Otero e Beatriz Barros, agradeço a compreensão e o apoio durante o período difícil e cansativo da redação deste texto. 
Aos meus amigos, que felizmente são muitos, agradeço sempre pela presença que preenche a minha vida de leveza, força e alegria. Certamente agora terei mais tempo para desfrutar da companhia de todos!

Ao Augusto Leão, agradeço o apoio na transcrição das entrevistas e à Aliandra Barlete e à Clarissa Dri, agradeço o olhar atento e analítico na revisão das primeiras versões deste texto. A disponibilidade e a generosidade de vocês é notável.

Nesse percurso também colaboraram com debates, parcerias em Congressos, indicações de bibliografias, ou ainda com palavras e abraços nos momentos de angústia: Marília Budó, Izabela Araújo, Letícia Dyniewicz, Lucas Tasquetto, Tatiana Waldman, Táli Pires de Almeida, Patricia Gainza, Thais Menezes, Vinícius Fialho, Bruna Roncato, Maria Helena Faller, Denise Avancini, Bruna Moser, Marina Brun, Cícero Luz, Rachelle Balbinot, Renan Quinalha, Amanda Madureira, Antonella Levatino, Aysen Ustubici, Melissa Navarra e muitos outros que não cabem nestas páginas.

Aos meus pais e irmãos agradeço o apoio e a compreensão neste longo processo que se apropriou de fins de semana e férias, rareando os momentos de convívio.

Ao Pedro, agradeço todo o amor, cuidado e parceria nestes últimos seis meses. Chegou na hora certa e não quero que nunca mais me deixe. 
Mi vida va prohibida

Dice la autoridad

Manu Chao

(Clandestino)

Liberdade é pouco. O que desejo ainda não tem nome. (...) [R]epentinamente pensei, quase sem antecedentes, quase sem ligação com as coisas: o movimento explica a forma. 


\section{RESUMO}

As migrações internacionais contemporâneas, ditas globais, têm sido tratadas como um problema ao qual as políticas migratórias dos Estados nacionais precisam dar uma solução. $\mathrm{O}$ enfoque desta tese busca desvelar a politização da construção dessas políticas em torno do conceito da irregularidade migratória e das transformações decorrentes da atual dinâmica transnacional das migrações, associada às subjetividades dos migrantes como prática política de transformação da cidadania nacional. Diante desse quadro os discursos patrocinados pelas Organizações Internacionais em torno da ideia de gestão das migrações se mostram nada transformadores em razão de seu caráter tecnocrático. No Brasil, os discursos referentes a uma política migratória baseada nos direitos humanos são predominantes, mas ainda não concretizados. Através de entrevistas com atores governamentais brasileiros busca-se aprofundar a análise sobre esta diretriz diante da amplitude das transformações que requer. Conclui-se que a cidadania sul-americana em construção, a partir do Acordo de Residência do Mercosul, tem características do que poderia vir a ser uma cidadania fundada no paradigma da mobilidade.

Palavras-chave: Autonomia das migrações internacionais, Transnacionalismo, Irregularidade migratória, Cidadania sul-americana, Direitos Humanos 


\begin{abstract}
International migration has been considered a problem to be solved by national states' national migration policies. The study aims at revealing the political aspects arising as a result of policy development around the concept of migration irregularity and of the changes arising on the transnational dynamics of migration associated with the immigrants subjectivity as a political practice of citizenship transformation. The analysis has shown that the migration management discourse coming from the international organizations proves to be insufficient to any transformation due its technocratic features. In Brazil, even though the prevailing migratory policy discourse is based on human rights, policy implementation has yet to take place. Through interviews with Brazilian governmental actors it was intended to further the analysis on this directive due to the meaningful changes it requires. Conclusion reveal that the South American citizenship built upon the implementation of the Mercosur Residency Agreement presents some features of citizenship grounded on the mobility paradigm.
\end{abstract}

Key-words: International migration autonomy, Transnationalism, Migration irregularity, South-american citizenship, Human Rights. 


\section{RÉSUMÉ}

Les migrations internationales contemporaines, dites globales, sont perçues comme un problème auquel les politiques migratoires des Etats nationales doivent résoudre. Cette thèse cherche à dévoiler les déterminants politiques qui influencent la construction de ces politiques autour du concept d'irrégularité migratoire, ainsi que des changements relatifs à la dynamique transnationale actuelle des migrations associées aux subjectivités des migrants comme pratique politique de transformation de la citoyenneté nationale. Face à ce scenario, les discours des organisations internationales autour de l'idée de gestion des migrations sont insuffisants pour quelque transformation en raison de son caractère technocratique. Au Brésil, les discours sur une politique migratoire basée sur les droits de l'homme sont prédominants, mais toujours pas concrétisées. Au moyen des entretiens avec des acteurs gouvernementaux brésiliens on envisage à approfondir l'analyse sur le chemin proposé en face du degré de transformation qu'il requiert. On montre que la citoyenneté sud-américaine qui est en construction à partir de l'accord de résidence du Mercosur a des caractéristiques qui peuvent correspondre à une citoyenneté fondée sur le paradigme de la mobilité.

Mots-clés: Autonomie des migrations internationales, Transnationalisme, Irregularité migratoire, Citoyenneté sud-américaine, Droits de l'homme. 


\section{LISTA DE SIGLAS}

ACNUR - Alto Comissariado das Nações Unidas para Refugiados

ADI - Ação Direta de Inconstitucionalidade

AG - Assembleia Geral da ONU

AI - Anistia Internacional

BCP - Benefício de Prestação Continuada

BRAiN - Brasil Investimento \& Negócios

CNIg - Conselho Nacional de Imigração

CIDH - Corte Interamericana de Direitos Humanos

CMMI - Comissão Global sobre Migrações Internacionais

CF - Constituição Federal

CMC - Conselho Mercado Comum (Mercosul)

COM - Comissão Europeia

CONARE - Comitê Nacional de Refugiados

CSM - Conferência Sul-americana sobre Migrações

CPF - Cadastro de Pessoa Física

DITEM - Diretório de Instituições envolvidas com a temática migratória

ECOSOC - Conselho Econômico e Social da ONU

ENAFRON - Estratégia Nacional de Segurança Pública nas Fronteiras

FEM - Foro Especializado Migratório - Mercosul

GAMM - Global Approach to Migration and Mobility

GCIM - Global Commission on International Migration

GFMD - Global Forum on Migration and Development

GMG - Global Migration Group

HRW - Human Rights Watch

ILO - International Labour Organization

INIC - Instituto Nacional de Imigração e Colonização

IOM - International Organization for Migration

LOAS - Lei Orgânica de Assistência Social

MESCA - Grupo de Estados mediterrâneos e escandinavos durante as negociações da Convenção da ONU sobre Trabalhadores Migrantes

MJ - Ministério da Justiça 
MINUSTAH - Missão das Nações Unidas para a estabilização no Haiti

MRE - Ministério de Relações Exteriores

MTE - Ministério do Trabalho e Emprego

Mercosul - Mercado Comum do Sul

OIM - Organização Internacional para as Migrações

OIT - Organização Internacional do Trabalho

ONU - Organização das Nações Unidas

PE - Parlamento Europeu

PF - Polícia Federal

SAE - Secretaria de Assuntos Estratégicos da Presidência da República

SUPRA - Superintendência de Política Agrária

TCE - Tratado que institui a Comunidade Européia

TFUE - Tratado sobre o funcionamento da União Européia

UE - União Europeia

UN - United Nations

Unasul - União de Nações Sul-americanas

UNRWA - Agência das Nações Unidas de Assistência aos Refugiados da Palestina 


\section{LISTA DE ENTREVISTAS}

Entrevistado 01 - Brasília, 02.04.2013 - representante governamental - MRE

Entrevistado 02 - Brasília 04.04.2013 - conselheiro do CNIg - confederação patronal

Entrevistado 03 - Brasília, 05.04.2013 - representante governamental - MTE

Entrevistado 04 - Brasília, 05.04.2013 - assessor parlamentar - Câmara dos Deputados

Entrevistado 05 - Brasília, 05.04.2013 - representante governamental

Entrevistado 06 - Brasília, 06.04.2013 - conselheiro do CNIg (não-governamental)

Entrevistado 07 - Brasília, 08.04.2013 - conselheiro do CNIg (não-governamental)

Entrevistado 08 - Brasília, 08.04.2013 - ex-representante governamental

Entrevistado 09 - Brasília, 08.04.2013 - assessor parlamentar - Senado Federal

Entrevistado 10 - Brasília, 09.04.2013 - representante governamental - MJ

Entrevistado 11 - Brasília, 09.04. 2013 - conselheiro do CNIg - Universidade

Entrevistado 12 - Brasília, 09.04. 2013 - representante governamental

Entrevistado 13 - São Paulo, 17.04.2013 - conselheiro do CNIg - sindicatos 


\section{SUMÁRIO}

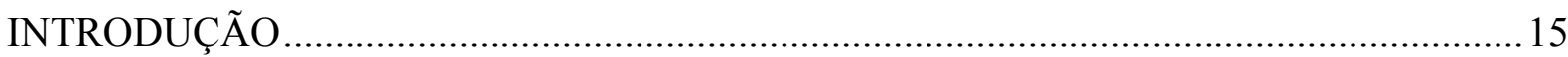

1. MIGRAÇÕES INTERNACIONAIS, UMA QUESTÃO RADICALMENTE POLÍTICA: A LUTA PELA MOBILIDADE E A PRODUÇÃO DE IRREGULARIDADE .......................23

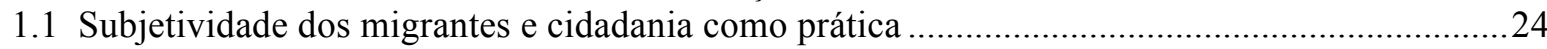

1.2 Irregularidade migratória: migração-problema e migração-negócio ............................................41

$1.3 \mathrm{O}$ tratamento internacional das migrações: tecnocracia a serviço do status quo ...........................56

2. O PAPEL DOS DIREITOS HUMANOS NA CONSTRUÇÃO DE UMA NOVA POLÍTICA MIGRATÓRIA NO BRASIL E NA TRANSFORMAÇÃO DA CIDADANIA...72

2.1 Cidadania moderna, política migratória brasileira e regional.....................................................73

$2.2 \mathrm{O}$ discurso e a sua difícil efetivação: tensões na ordem política, legal e administrativa ...............92

2.3 Cidadania não-excludente: paradigma da mobilidade .............................................................110

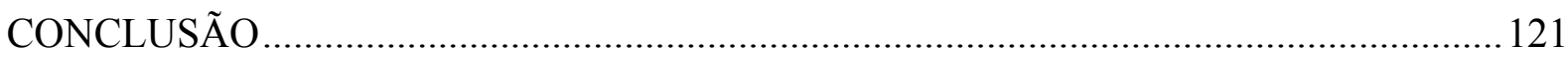

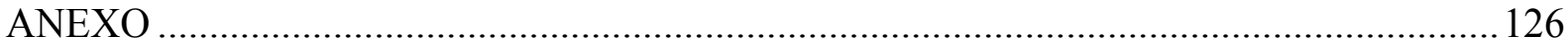

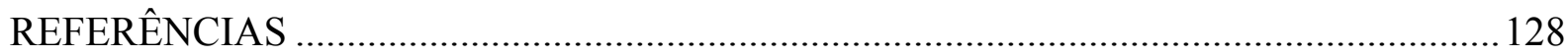




\section{INTRODUÇÃO}

A migração é constituinte do processo de formação da maior parte das comunidades políticas que hoje chamamos de Estado (MOULIN, 2011). Conflitos, evoluções tecnológicas e crescimento demográfico são fatores que, ao longo da história, impulsionaram a movimentação das pessoas. Além de consequência de eventos como estes, as migrações também constituíram elemento estrutural de grandes eventos da história como o colonialismo, a industrialização, a formação do mercado de trabalho para o capitalismo e, como dito, a formação dos Estados nacionais (CASTLES; MILLER, 2009).

Dizer que as migrações são hoje um fenômeno global, não refere-se tanto ao volume destes movimentos que foram significativos também em outros momentos da história, mas ao fato que hoje elas interessam a quase todos os locais do globo (WIHTOL DE WENDEN, 2013). Também significa que as migrações estão submetidas às transformações que os processos globais transnacionais imprimem às relações sociais, econômicas e políticas na contemporaneidade, da mesma forma que no passado as migrações estiveram inseridas nos contextos das outras grandes transformações de cada época.

O colonialismo foi a filosofia que embasou a dominação dos povos da Ásia, África e América Latina desde o século XVI até o século XX. A proclamada superioridade de uns povos sobre outros e de um caminho único para o desenvolvimento e a modernização, justificou a invasão e a dominação de territórios, e a subjugação dos povos nativos. Além do deslocamento de indivíduos das metrópoles para a dominação das colônias, os sistemas coloniais utilizaram-se largamente da mão-de-obra escrava, trazida sobretudo da África, e depois substituída pelos imigrantes, em sua maioria europeus, no caso do Brasil ou por indentured workers ${ }^{I}$ nas colônias britânicas e holandesas (CASTLES; MILLER, 2009).

A industrialização, por sua vez, foi possível diante da grande disponibilidade de força de trabalho vinda sobretudo do campo. O mercado de trabalho capitalista construiu-se a partir da possibilidade de mobilidade dos trabalhadores. Com o fim do sistema de produção feudal e a liberação dos trabalhadores de seu vínculo com a terra, o sistema capitalista pode então estruturar-se com base no trabalho assalariado.

Do ponto de vista conceitual, a migração internacional vincula-se inexoravelmente à

\footnotetext{
${ }^{1}$ Os indetured workers, sobretudo chineses e indianos, mas também japoneses, eram deslocados para trabalhar nas colônias, submetidos a contratos de trabalho temporários muito estritos.
} 
ideia de Estados nacionais, materializando-se por meio do cruzamento das fronteiras políticas de tais Estados (CASTLES, 2009; SAYAD, 1999). As migrações internacionais, assim, só existem porque existem as fronteiras. Juridicamente deveriam constituir a exceção no sistema de Estados-nação, que constrói-se sobre a tríade: governo, povo e território, em que um povo estável (ou estabilizado), localizado em um território definido, é ligado a um governo e a um ordenamento jurídico que possui jurisdição (poder) sobre aquele território. O migrante é aquele membro de um Estado que se desloca para outro território e portanto, se coloca sob a jurisdição deste outro Estado.

Estes movimentos, no entanto, nunca foram exceção, o que revela o caráter excludente do Estado-nação em sua origem. A diferenciação entre nacionais e não-nacionais cada vez menos se justifica diante da internacionalização dos direitos humanos, através institucionalização e da regulamentação internacional destes, na segunda metade do século XX. As comunidades são sistemas de inclusão e exclusão, e o questionamento sobre se a nacionalidade é um critério moral significativo para essa exclusão se fortalece em um momento no qual as lógicas da globalização abrem as portas para a construção de novas relações entre universalidade e diferença nas estruturas políticas, com base nas próprias ideias modernas de liberdade e igualdade (LINKLATER, 1998).

Do latim migratio, migração significa passagem de um lugar para outro. No caso da migração internacional, estes lugares são Estados nacionais diferentes. A geografia, ao tratar da questão da mobilidade internacional, trabalha com os conceitos de imigração e emigração. A partir do ponto de vista de um Estado nacional, imigração indica a entrada de pessoas de outros países em seu território, e a emigração, por sua vez, a saída de pessoas deste. Em alguns casos, a imigração pode incluir nacionais retornados e a emigração, os estrangeiros que deixaram o país. Esta é uma realidade cada vez mais presente no atual cenário de crescente transnacionalismo, em que é comum migrar mais de uma vez durante a vida estabelecendo-se múltiplos vínculos de pertencimento (FAIST, 2008).

No Brasil, por exemplo, nos questionários do Censo 2010 (IBGE, 2010a e 2010b) perguntou-se sobre emigração e imigração internacional. Sobre a emigração internacional, havia perguntas no questionário básico aplicado a todos os entrevistados: "3.01 - Alguma pessoa que morava com você(s) estava morando em outro país em 31 de julho de 2010?" e também "3.05 - Ano da última partida para morar em outro país". No questionário da amostra perguntou-se sobre a imigração internacional: "6.20 - Qual é a sua nacionalidade? 1 brasileiro nato; 2 - naturalizado brasileiro; 3 - estrangeiro". E na sequência: "6.22 - Qual é a unidade da Federação (Estado) ou país estrangeiro de nascimento?" e "6.26 - Em que unidade 
da Federação (Estado) e município ou país estrangeiro morava em 31 de julho de 2005?". Assim, apenas as perguntas 6.20 e 6.22 , da amostra captam o chamado estoque de pessoas de nacionalidade diferente da brasileira e presentes no território do país. As perguntas 3.01 do questionário básico e a 6.26 do questionário da amostra referem-se a fluxos e não diferenciam entre nacionalidades. Essa construção inclui pessoas de nacionalidade estrangeira que eventualmente tenham deixado o país (em resposta à pergunta 3.01) e brasileiros que estivessem morando fora do Brasil 5 (cinco) anos antes do Censo. Assim, o Censo inclui brasileiros retornados e exclui estrangeiros que vivem há mais de 5 (cinco) anos no país.

Para a finalidade deste trabalho, no que se refere à discussão teórica, essa diferenciação é desprovida de interesse, pois a questão da autonomia dos movimentos migratórios, da construção de espaços transnacionais e da transformação da cidadania dizem respeito a paradigmas que envolvem os sujeitos migrantes, onde quer que estejam e independentemente de suas rotas. De forma geral, também não interessa a diferenciação legal entre migrantes temporários, permanentes, etc. Ainda que existam diferenças na realidade quotidiana que cada um destes vive - as quais serão apontadas quando couber — de forma ampla a discussão refere-se ao paradigma da política para as migrações no Brasil e estas categorias não descrevem as suas trajetórias (FAIST, 2008) marcadas sempre pela diferenciação entre nacionais e estrangeiros. Assim, as diferentes categorizações entre os migrantes não devem ser motivo de uma disputa entre os que têm algum direito e os que têm menos do que estes, se a busca é por uma política migratória com base nos direitos humanos, iguais para todos.

Quando aqui se fala de migração, está clara a ideia de estabelecimento em outro país. Assim, não se considera aqui o movimento do turista ou do indivíduo em trânsito, pois ainda que a eles também devam ser garantidos direitos durante a sua presença em território estrangeiro, estes não passam a compor o povo daquele país. Os demais, independentemente do enquadramento jurídico ou de sua motivação, muitas vezes difícil de delinear, são todos migrantes, incluídos aí os refugiados. Assim, migração internacional e migrantes são termos que englobam praticamente toda a realidade da movimentação de pessoas entre Estados nacionais. Prefere-se esses termos à expressão mobilidade humana porque eles demarcam a realidade excludente dos Estados nacionais em que esta movimentação ocorre. O paradigma da mobilidade é oposto ao paradigma nacional. Há uma disputa entre este novo que surge a partir da própria dinâmica autônoma dos migrantes e a consciência política que constrói-se a partir daí e os esforços do paradigma nacional excludente para se manter vigente. A opção pelo termo migrações internacionais busca evidenciar a luta que está em curso diante do 
crescimento e da transformação das migrações, realidade que, segundo o paradigma dos Estados-nação, deveria ser excepcional, ou melhor, controlada.

A mobilidade é a qualidade do que é móvel. Atualmente, são poucos os sujeitos realmente móveis, os quais podem deslocar-se facilmente e sem ser submetidos a controles invasivos e barreiras físicas e jurídicas ${ }^{2}$. O movimento de indivíduos através das fronteiras é um dado empírico, mas esta movimentação, não raro, desafia a ordem jurídico-política posta e ocorre por meio de batalhas que se travam em muitas fronteiras e geram violações de direitos diversas. A apreensão desse dado e a construção de um novo paradigma, que é o paradigma da mobilidade, para o tratamento das migrações internacionais e para a cidadania a partir da atual realidade transnacional embasam as demandas pelo direito a migrar e também a não migrar. Pleiteia-se uma migração sem restrições, baseada em condições não-exploratórias, em razão de e promovendo uma maior equidade econômica e de oportunidades entre as diversas regiões do mundo.

A leitura aqui proposta insere-se no quadro de abordagens que partindo das teorias sociológicas do transnacionalismo a respeito das migrações, propõe-se a fazer uma leitura política destas. O transnacionalismo já havia proporcionado a passagem dos migrantes da passividade das teorias assimilacionistas à "agência" a respeito de seus projetos migratórios, e portanto de sua própria identidade, mas lhes faltava colher as consequências políticas ou até mesmo o contexto político em que ocorrem estas transformações. A "agência" dos imigrantes refere-se às decisões individuais (ou de grupo) de migrar em busca de oportunidades, sobrevivência ou enfrentamento de situações de crise, entre outros.

A abordagem da autonomia das migrações de Sergio Mezzadra, descrita grandemente no livro Diritto di Fuga (2006), e a abordagem do politicizing mobility e mobilizing politics de Vicki Squire (2011) caminham neste sentido constituem o marco teórico desta tese. Considerando as práticas dos migrantes como práticas políticas, e entendendo o contexto econômico e político em que se inserem as suas lutas, busca-se desenhar qual seriam os desdobramentos destas reivindicações muitas vezes não pronunciadas ou de contornos disformes. Antes, no entanto, é preciso compreender como se constrói o estado de coisas contra o qual se colocam nesta luta, as políticas migratórias construídas a partir de uma metodologia nacional e centradas no conceito de irregularidade desenham o quadro em que se estabelecem a dominação econômica e a exploração laboral dos migrantes, no contexto do

\footnotetext{
${ }^{2}$ Estes são os únicos cidadãos pós-nacionais. Ver: SASSEN, 2006.
} 
capitalismo.

Dentro do quadro do Estado-nação e da cidadania nacional, as políticas migratórias enfatizam o nacionalismo e a prerrogativa estatal de excluir os migrantes indesejados. Com relação aos que entram de forma autorizada, além das exigências para a obtenção desta, aplicam-se as exigências de integração à comunidade nacional, pois a diferença hierarquiza. Com relação aos que não obtém autorização, resta a criminalização ou o favor das anistias, que mantêm o controle. Assim, o foco do combate é o próprio critério de atribuição da cidadania formal, a nacionalidade, cujos contornos excludentes são colocados sob os holofotes pelos movimentos migratórios contemporâneos.

No que se refere à questão do dever-ser, objeto da ciência jurídica, há um campo teórico consolidado a respeito das garantias de direitos humanos que limitam a ação do Estado e protegem os indivíduos. Porém, apesar do movimento de internacionalização dos direitos humanos, a instância encarregada de sua aplicação e garantia, por excelência, continuou sendo o Estado nacional. Com as migrações contemporâneas, surgem indivíduos com identidades múltiplas, transnacionais e em movimento, pondo em questão a coincidência entre comunidade nacional, comunidade cultural e comunidade política. Essa simultaneidade nunca existiu perfeitamente, mas a tendência é que as sociedades se tornem cada vez mais plurais e transnacionais.

Nesse contexto, é necessária uma ressignificação dos direitos humanos e da cidadania (REIS, 2007). Os direitos humanos como um campo de lutas, a partir das ideias de liberdade e igualdade, sem hierarquizações ou julgamentos culturais, e a cidadania como prática de construção destes, transformando-a de um status passivo para um conceito dinâmico. Diante da exclusão injustificável a que são submetidos os imigrantes, a ordem atual que os submete a tal situação deve ser questionada. As respostas institucionais apresentadas até então frente a estas mudanças são fracas (LINKLATER, 1998). A cidadania europeia, por exemplo, apenas amplia a extensão da aplicação do critério nacional.

No Brasil, o forte e amplo discurso de construção de uma política migratória baseada em direitos humanos precisa ser confrontado com a profundidade das transformações políticas necessárias para garanti-los a estes indivíduos. Para este trabalho foram realizadas, no primeiro semestre do ano de 2013, entrevistas com os principais tomadores de decisão sobre a política migratória brasileira, nos três ministérios que possuem competências sobre o tema: Relações Exteriores (MRE), Trabalho e Emprego (MTE) e Justiça (MJ). Além disso, foram entrevistados, cinco outros membros do Conselho Nacional de Imigração (CNIg), representando sindicatos patronais, trabalhadores, sociedade civil e universidade. Finalmente 
foram realizadas também quatro entrevistas exploratórias a respeito da tramitação de dois projetos de lei (PL), os PLs 5655/2009, do PLS 288/2013, do histórico da negociação dos Acordos de Residência do Mercosul e outras iniciativas legislativas. A escolha destes atores justificou-se em razão de serem os responsáveis pela formulação das políticas que dizem respeito às migrações no Brasil e por permitirem captar a percepção dos atores mais envolvidos com o tema atualmente. Que o tema das migrações ainda esteja restrito a um pequeno círculo de atores governamentais também é sintomático das dificuldades que suas propostas têm de avançar internamente no governo.

As entrevistas foram referidas aqui através de números. Nos casos em que foi solicitada a preservação da identidade pelo entrevistado, aponta-se apenas se trata-se de ator governamental ou conselheiro do CNIg não-governamental. A transcrição das entrevistas e os termos de consentimento encontram-se arquivados com a autora.

Através destas, buscou-se verificar a amplitude da compreensão das implicações de seus discursos de direitos humanos frente a questões-chave nas quais se manifestam elementos nacionalistas. De forma geral, os discursos são bastante consistentes e coerentes, ainda que linhas mais concretas de uma proposta nesse sentido ainda não estivessem estabelecidas à época das entrevistas. Muito recentemente foi divulgado o texto de um novo Anteprojeto, redigido por especialistas, e agora submetido à consulta pública. O futuro deste ainda é incerto já que foram muitas as propostas de substituição do Estatuto do Estrangeiro (Lei $6815 / 80)^{3}$ falidas. O MJ, nas entrevistas realizadas, revelou acreditar que a participação social no processo é a chave para que esta proposta tenha um fim diferente.

O que é certo é que a discussão no governo, no Congresso Nacional e na sociedade civil precisa desenvolver-se e para tanto é preciso ter maior clareza sobre as implicações do discurso dos direitos humanos na política migratória. Os Acordos de Residência do Mercosul $^{4}$, elemento mais significativo na construção de uma cidadania sul-americana projetada tanto pelo Mercosul como pela União de Nações Sul-americanas (Unasul), parece ser uma grande pista para estes desenvolvimentos, uma inovação na matéria, não tanto pela ideia de facilitação na circulação dentro de uma região, mas pelo fundamento para a liberalização, não ligado a justificativas laborais ou familiares. Este trabalho pretende, assim, contribuir teoricamente e analiticamente neste sentido, pois o que aparece pouco nos discursos é a compreensão de que a superação do paradigma nacional requer transformações estruturais

\footnotetext{
${ }^{3}$ Sobre o Estatuto do Estrangeiro, ver p. 86.

${ }^{4}$ Promulgados pelos Decretos 6964 de 29 de setembro de 2009 e 6975 de 07 de outubro de 2009. Ver mais detalhes na p. 92.
} 
amplas nos sistemas econômicos e políticos. Assim, as lutas dos migrantes conectam-se com todas as demais lutas pós-capitalistas.

A investigação aqui desenvolvida, no entanto, foca nas lutas para a construção de uma nova política para as migrações no Brasil. O objetivo é estabelecer os parâmetros para que se possa efetivamente falar de proteção dos direitos humanos dos migrantes no âmbito de uma política migratória. De forma mais específica, busca-se clarificar as transformações necessárias para a realização deste projeto dentro de um sistema internacional de soberanias nacionais em que a reivindicação de direitos por parte destes sujeitos "deslocados" choca-se com a prerrogativa soberana dos Estados nacionais (2.2).

Antes porém, como forma de demonstrar a urgência da construção de um novo paradigma para o tratamento das migrações - diferente do paradigma restritivo e seletivo praticado pelos países do Norte global ${ }^{5}(2.3)$ - , é necessário compreender a própria dinâmica dos movimentos migratórios, seu contexto subjetivo e estrutural (1.1), e a incapacidade da cidadania moderna nacional em dar respostas satisfatórias a estes processos (2.1). As respostas construídas em forma de políticas migratórias nas últimas décadas são reapresentações do mesmo nacionalismo que delineou os contornos do Estado-nação europeu há mais de dois séculos. Apenas mecanismos para a manutenção de um critério excludente, violento e imposto, que viola os direitos humanos dos imigrantes em nome de interesses econômicos viabilizados por discursos securitários (1.2 e 1.3).

A base teórica para estas análises assenta-se e desenvolve-se a partir de uma ampla literatura sobre as migrações, de origem sociológica, com desenvolvimentos para outras áreas como a política, as relações internacionais e o direito. $\mathrm{O}$ transnacionalismo descreve com perspicácia a atual dinâmica dos indivíduos relativamente às fronteiras nacionais, sua capacidade de estabelecer relações, vínculos e pertencimentos através e apesar destas. Criticase, no entanto, que tais análises não deixem de reproduzir um nacionalismo metodológico, o qual, de tão enraizado, formata as próprias ideias que confrontam os pressupostos do nacionalismo. Assim, nacionalidade, vistos, irregularidade, autorizações de trabalho,

\footnotetext{
5 Sobre os conceitos de Norte global e Sul Global, ver, por exemplo, o Prefácio da nova edição de SANTOS, 2013: O Sul é aqui concebido como metáfora do sofrimento humano, injusto e sistêmico, causado pelo capitalismo e pelo colonialismo modernos. Esta concepção do Sul só em parte se sobrepõe com o Sul geográfico, o conjunto de países e regiões do mundo que foram submetidos ao colonialismo europeu (...). No sentido que lhe é atribuído nas epistemologias do sul, o Sul também existe no interior do Norte geográfico sob a forma dos grupos sociais discriminados, vítimas do racismo e da xenofobia. Paralelamente, no interior do Sul geográfico houve sempre pequenos Nortes, as pequenas europas, constituidas pelas elites locais que beneficiaram da dominação capitalista e colonial e que, depois das independências, continuaram a exercê-la, por suas próprias mãos, contra as classes e grupos sociais subordinados.
} 
soberania, entre outros, permanecem no centro do debate sobre as migrações, inclusive da literatura que os questiona.

A passagem destes postulados para o campo da política e das relações internacionais requer justamente a revisão dos pressupostos que estruturam as comunidades políticas modernas na forma do Estado nacional e o autorizam a definir quem tem direitos em seu território e quem deve ser excluído, dos direitos, do território ou de ambos. A abordagem da autonomia das migrações propõe inverter o olhar e enxergar os movimentos migratórios a partir do ponto de vista dos migrantes e suas subjetividades. Ao deixar de tratá-los como objetos, a questão dos seus direitos vêm à tona e os Estados deixam de ter a prerrogativa soberana de exclusão sobre suas vidas e seus corpos. Isso, por sua vez, atinge diretamente os contornos do Estado-nação e as relações com seus pares na comunidade internacional.

O questionário aplicado aos entrevistados baseou-se nesta compreensão teórica de que a garantia dos direitos dos migrantes não se constrói com uma metodologia nacionalista. Os institutos jurídicos e políticos sobre migrações vigentes na América do Sul também foram confrontados com estes postulados teóricos e, da mesma forma, buscou-se verificar o quanto reproduzem o nacionalismo metodológico, ampliando-o, ou apresentam indícios da efetivação de um paradigma diverso, o paradigma da mobilidade que emana desta cartografia das lutas dos migrantes na América do Sul. 


\section{MIGRAÇÕES INTERNACIONAIS, UMA QUESTÃO RADICALMENTE POLÍTICA: A LUTA PELA MOBILIDADE E A PRODUÇÃO DE IRREGULARIDADE}

Radical refere-se à raiz, à base de algo e não ao acessório. Uma questão radicalmente política é uma questão que atinge a base da política. E o que é política? Refere-se ao exercício do poder que, a partir da modernidade, foi organizado em base territorial exclusiva. Os governos soberanos dos Estados-nação passaram a dispor do monopólio do uso da força em um território delimitado e sobre uma população delimitada também: "os nacionais".

A discussão sobre como ocorreu este processo não é objeto específico deste trabalho, mas a imagem predominante é a do contrato social, uma abstração criada para explicar e dar legitimidade ao poder exclusivo e abstrato (operacionalizado por normas) dos Estados nacionais. Segundo a teoria contratualista, a base social do poder do Estado é então, o povo (BONAVIDES, 2003). Muitas teorias até hoje, discutem estes postulados, demonstrando, por exemplo, que o poder hoje é muitas vezes exercido contra o povo, e não para e a partir do povo (DUSSEL, 2007).

Hannah Arendt afirmou que "[a] política trata da convivência entre diferentes (...), [ela] surge no intra-espaço [entre-os-homens] e se estabelece como relação, [e seu] sentido (...) é a liberdade" (ARENDT, 2002) . De forma mais clara, a ação política e a liberdade são sinônimos (TORRES, 2007). A aversão pela política resulta assim em imobilismo, passividade e renúncia ao exercício da cidadania. A autora não coloca ênfase no domínio entre governantes e governados, mas na ação de cada indivíduo, de forma que "as instituições políticas são manifestações e materializações do poder; petrificam e decaem quando o poder vivo do povo cessa de lhes sustentar" (ARENDT, 2004). A imprevisibilidade da ação política também é sublinhada em seus textos, a vida política não é "algo regularizado e determinado (...). Ao iniciar algo, os homens se veem livres inclusive dos motivos que os levaram a agir" (...) (TELES, 2013).

As migrações são uma questão radicalmente política no sentido de que incidem sobre a própria configuração do Estado nacional. Pensar a imigração é pensar o Estado, seus termos de inclusão e exclusão (SAYAD, 1999). É nesse sentido que a mobilidade é uma prática democrática de busca da igualdade (ARADAU; HUYSMANS, 2009) e um exercício de liberdade (MEZZADRA, 2006) contra a exclusão gerada pela ordem político-jurídica nacional e capitalista. 
A literatura sobre o transnacionalismo, eminentemente sociológica, documentou de forma consolidada as dinâmicas sociais estabelecidas pelas migrações (FAIST, 2008). Entre os próprios autores, no entanto, existe a preocupação de conseguir transpor para a discussão política as implicações de suas conclusões. A superação do nacionalismo metodológico no estudo das migrações (GLICK-SCHILLER, 2009) permite repensar o político tendo em vista os amplos processos transnacionais em que o Estado está inserido, trazendo uma nova perspectiva às discussões sobre a democracia global que, em geral, se limitam a pensar o aumento de escala das instituições e lógicas nacionais como resposta a estes novos processos (ARADAU; HUYSMANS, 2009).

Os movimentos migratórios fazem parte da história da humanidade, sendo estruturais no atual sistema de produção capitalista. No que se consolidou como sistema internacional de Estados nacionais, a escolha de quem pode entrar e quem não pode entrar no território nacional é considerada uma prerrogativa soberana. Os critérios para esta seleção sempre atenderam aos interesses nacionais, notadamente de seus mercados de trabalho e, mais recentemente, de suas identidades nacionais. Neste sistema regulatório, é clara a objetificação dos seres humanos, sem voz na construção das políticas migratórias.

A insurgência e a crise atual decorrem da imprevisibilidade e da massificação das migrações, frutos dos processos globais e de suas transformações sociais, conjugados às decisões autônomas dos migrantes e às práticas de cidadania que desconhecem os limites institucionais postos pelos Estados (1.1). Esta compreensão confronta-se com os discursos da migração-problema a partir da ideia de irregularidade migratória, as quais justificam a securitização para operacionalizar a seletividade e a manutenção do controle sobre as migrações, sobre a conformação do povo e do território pelo Estado nacional (1.2). Como alternativa de solução para este conflito, as Organizações Internacionais propõe a gestão das migrações internacionais para o benefício de todos, uma mudança no nível do discurso que não implica transformações políticas que garantam direitos aos migrantes (1.3).

\subsection{Subjetividade dos migrantes e cidadania como prática}

As migrações não são um fenômeno, no sentido de que não são eventos raros ou extraordinários. Muito menos um fenômeno similar aos da natureza, a exemplo do que muitas metáforas utilizadas dão a entender: onda, aluvião, inundação, etc., eis que são estrutural e 
subjetivamente determinados. Assim, enquadram-se melhor no conceito de processo, uma sucessão de atos dirigidos a um determinado fim. Um processo que é constante na história da humanidade.

No Brasil, é relativamente pacífico e tendencialmente crescente o reconhecimento da igualdade de direitos entre nacionais e imigrantes às prestações estatais (saúde, educação, previdência social, etc.). O relativo consenso claramente refere-se aos imigrantes regularmente aceitos pelos Estados. Nesse sentido, a regularização por meio de anistias migratórias e acordos bilaterais tem sido medida recorrente para incluir os imigrantes na população destinatária destes direitos.

Estas medidas ad hoc, no entanto, não impedem a constância da presença de imigrantes não-autorizados, o que complica essa equação. Como garantir direitos para pessoas não reconhecidas pelo ordenamento jurídico? Apesar de à primeira vista parecer paradoxal, é o que tem ocorrido em diversos países ${ }^{6}$, inclusive no Brasil ${ }^{7}$, e é o que dispõe um inteiro capítulo da Convenção das Nações Unidas sobre a Proteção dos Direitos de Todos os Trabalhadores Migrantes e Membros de suas Famílias de 1990 (doravante, Convenção da ONU sobre Trabalhadores Migrantes). Estas medidas aparentam ser uma tímida e nãodeclarada aceitação de que as migrações são "uma parte normal das relações sociais" (CASTLES, 2004) ou um movimento social em seu sentido literal (MEZZADRA, 2011), além da insuficiência do critério da nacionalidade para a titularidade da cidadania.

Ao longo da história, as percepções, cultural, econômica, política e jurídica, assim como as condições objetivas de mobilidade, sofreram grandes mudanças. Houve uma época, na Europa, em que era mais fácil entrar em outro território do que deixar o seu. Os Estados, recém constituídos, necessitavam de um povo estável que pudesse defender o território nas guerras e pagar impostos (WIHTOL DE WENDEN, 2013). A partir do século XVI, a colonização das Américas foi um processo que trouxe muitos europeus ao continente americano. Durante os séculos XIX e XX ocorreram as grandes migrações do Velho para o Novo Mundo. Milhares de europeus se estabeleceram em toda a América, dando nova

\footnotetext{
${ }^{6}$ A este propósito veja-se o relatório: EUROPEAN UNION AGENCY FOR FUNDAMENTAL RIGHTS, 2011.

${ }^{7}$ No Estado e no Município de São Paulo, há normativas que explicitam o direito de matricular-se e frequentar a escola às crianças imigrantes sem documentos. Ver: ESTADO DE SÃO PAULO. Resolução n. 10 de 1995 da Secretaria Estadual de Educação e PREFEITURA MUNICIPAL DE SÃO PAULO. Parecer do Conselho Municipal de Educação (CME) n 17/04 - Aprovado em 27 maio 04 - EMEF Infante Dom Henrique: alunos estrangeiros de ensino fundamental sem Registro Nacional de Estrangeiro (RNE). Sobre a efetiva garantia do direito humano à educação, ver: SCHILLING; MAGALHÃES, 2012. O acesso ao Sistema Único de Saúde também independe da condição migratória regular, o cartão do Sistema Único de Saúde (SUS) é fornecido mediante a apresentação de qualquer documento de identificação, inclusive do país de origem. Ver: BRASIL. 2011.
} 
configuração aos povos destes países, hoje considerados países formados pela imigração ${ }^{8}$.

A história política das migrações, incluídas estas mais antigas e hoje em grande parte romantizadas, constitui uma série de emergências descontínuas, muito distantes da lenda da plena integração ao país de destino: trata-se de uma história de lutas pelo reconhecimento (BOUBEKER, 2007) que continua a ser contada. As transformações que atingem as migrações não foram somente políticas, mas também sociais e econômicas.

O aumento da interconectividade permitiu que ideias e concepções sociais, culturais e econômicas circulassem muito mais intensamente. Os próprios migrantes promovem essa circulação, pelas quais mantêm ativos seus pertencimentos múltiplos. Eles cruzam fronteiras em busca da realização de seus desejos e muitas vezes, o fazem mais de uma vez durante suas vidas. Assim, a migração definitiva ou categorias como país de origem e país de destino, imigrante ou emigrante, migrante temporário ou permanente, migrante econômico ou refugiado não servem a descrever as suas trajetórias (FAIST, 2008). Os imigrantes vivem as suas vidas tanto dentro como através das fronteiras de múltiplos Estados-nação. Eles enviam remessas aos seus familiares, votam nas eleições do seu Estado de nacionalidade e, muitas vezes, também nas eleições de seus Estados de residência, etc.

Apesar disso, a migração normalmente é estudada sob o olhar do Estado-nação - o chamado nacionalismo metodológico ${ }^{9}$ — , como um fenômeno contido dentro de suas fronteiras, de onde provém a centralidade de conceitos como imigrante e emigrante, fluxos e estoques de imigrantes, etc. Esta moldura de análise gera dificuldades de compreensão do processo. As ciências sociais em geral cortam e excluem, analiticamente, tudo o que excede as fronteiras dos Estados-nação (WIMMER; GLICK-SCHILLER, 2003) enquanto as relações internacionais somente se ocupam das relações entre os Estados, também com dificuldades de analisar o que ocorre transversalmente e sem indagar-se sobre a importância do nacionalismo na formação deste sistema e a sua relação com os processos migratórios. Assim, entende-se que o imigrante está em um ou outro território, submetido à regulação nacional do país de destino, e às regras internacionais aceitas por estes mesmos Estados, invisibilizando-se a transnacionalidade do processo. Mesmo quando a transnacionalidade dos diversos processos globais é captada, isso não significa a superação do nacionalismo metodológico que permanece através do uso de categorias "nacionalizadas" na análise dos processos transnacionais.

\footnotetext{
${ }^{8}$ Ver, por exemplo: MARTIN, 2011; LEVY, 1974; SEYFERTH, 2000.

9 Trata-se da naturalização do regime global dos Estados-nação pelas ciências sociais. Ver: WIMMER; GLICK SCHILLER, 2003.
} 
Daí também derivam as extensas discussões a respeito do maior ou menor grau de integração às "sociedades de destino", considerando que as fronteiras da sociedade coincidem com as fronteiras nacionais e trabalhando com dois elementos: a sociedade nacional e o imigrante que vem de fora. Como consequência, referenda-se a ideia de que a divisão entre imigrante e nativo é um desafio fundamental à coesão social, como se todos os indivíduos e todos os grupos dentro deste território tivessem a mesma história, mesmos valores, costumes, etc. (GLICK-SCHILLER, 2009). No Brasil, está clara a ausência desta homogeneidade, não somente pela origem étnica múltipla do seu povo, mas também pela persistência de diferenciações sociais baseadas em raça e etnia entre os próprios brasileiros, como se verá.

Assim, a denúncia do nacionalismo metodológico que pauta as políticas migratórias direciona-se tanto à tentativa normativa de evitar/selecionar a entrada de imigrantes por parte dos Estados nacionais, como ao desejo, tentativa ou expectativa de que os imigrantes se assimilem à sociedade nacional. A pretensa sociedade homogênea e estática à qual deveriam assimilar-se os recém-chegados requer provas extraordinárias de lealdade para que sejam aceitos (MEZZADRA, 2006; RIGO, 2011). Por exemplo, na França, o migrante deve assinar um contrato que visa a estabelecer uma relação de confiança e de obrigação recíproca. $O$ acolhimento pelo país dependerá da boa integração do migrante, cujos indicadores dizem respeito sobretudo à língua e a ter um trabalho. Acolher não é então, receber o sujeito como ele é, mas como um sujeito que pode ser como quer o país (LE BLANC, 2010). Além da violência do processo de assimilação, a maior ou menor assimilabilidade também têm sido um critério de seleção das políticas migratórias e de hierarquização dos imigrantes entre desejados e indesejados, além de reduzi-los a típicos expoentes de uma cultura, desconhecendo a sua individualidade (MEZZADRA, 2006 e 2013).

Além disso, as sociedades latino-americanas recentemente começaram a discutir a necessidade de descolonização de suas cidadanias, rejeitando hierarquizações culturais e recepcionando as diferenças. Traçar um paralelo com as hierarquizações étnico-raciais dentro do Brasil é esclarecedor na demonstração dessa ficção de homogeneidade. Da mesma forma, as sociedades homogeneizadas das antigas metrópoles coloniais se veem hoje desafiadas com a presença de nacionais provenientes de suas ex-colônias. Em nova referência ao caso francês, onde o slogan das segundas gerações de migrantes é français comme les autres, é paradigmático esta demanda por tratamento igual, independentemente das diferenças de origem (WIHTOL DE WENDEN, 2010).

A compreensão dessa dinâmica transnacional das migrações é necessária para a construção de políticas que não estejam destinadas ao fracasso e/ou a resultados negativos, 
como violações de direitos. O reconhecimento do transnacionalismo não nega o papel significativo dos Estados nacionais, mas percebe a sua transformação (VERTOVEC, 2004). São suas políticas e leis que garantem direitos e distribuem prestações de forma predominante ainda hoje (GLICK SCHILLER, 2009). O problema está na disparidade entre as lógicas das políticas migratórias, hoje nacionais, e das forças que moldam e são moldadas pelos deslocamentos, que são transnacionais (CASTLES, 2004). Essas forças derivam dos processos transnacionais e globais nos quais os próprios Estados nacionais também estão inseridos e ajudam a moldar (GLICK-SCHILLER, 2009).

A mobilidade e a porosidade das fronteiras, em razão da capacidade dos movimentos migratórios de produzir os próprios espaços (transnacionais), desafia a geografia política construída em torno da norma soberana do Estado-nação (MEZZADRA, 2006). No cenário transnacional atual, a oposição entre interno e externo, ou inclusão e exclusão, é cada vez menos convincente, pois os indivíduos são incluídos de forma diferenciada (MEZZADRA, 2013; RIGO, 2011), segundo diversos níveis de reconhecimento de direitos operacionalizados por categorias migratórias — e jamais são totalmente excluídos. Quando irregulares, em sua presença física e sua vida real, praticam a cidadania ${ }^{10}$, ainda que desprovidos de reconhecimento jurídico.

Assim, o nacionalismo metodológico mascara o fato de que todos, imigrantes e nativos, estão inseridos nos mesmos processos transnacionais globais, ligados à expansão não somente dos meios de informação, mas sobretudo do capitalismo global e liberalizante que cria novos espaços e intensifica a dinâmica de exploração do trabalho migrante. A condição imigrante é assim uma importante fonte de mão de obra explorável para o desenvolvimento do capitalismo neoliberal.

Há grande discussão na literatura sobre os fatores determinantes da migração. Há quem polarize a discussão entre os fatores estruturais (objetivos) e os fatores subjetivos ${ }^{11}$. Os primeiros valorizam o papel das estruturas sociais em delinear as migrações (leis e políticas migratórias, redes de migração, mercado de trabalho, etc.), enquanto os últimos buscam

\footnotetext{
${ }^{10}$ Isin diferencia a cidadania como prática dos atos de cidadania. A cidadania como prática, em oposição à cidadania como status, foi amplamente teorizada pelos estudos críticos de cidadania e como resultado hoje é comum na literatura fazer a diferença entre cidadania formal e cidadania substantiva. A diferenciação proposta por Isin busca contemplar atos de reivindicação de direitos (atos de cidadania) de ações quotidianas dos imigrantes irregulares (prática de cidadania). ISIN, 2008. Não se considera essa diferenciação relevante porque até os atos quotidianos são políticos. As reivindicações de igualdade e exercício de liberdade, nas proporções que hoje tomam, pressionam para que se repense o conceito de cidadania.

${ }^{11}$ Sobre esta discussão, ver: BAKEWELL, 2010.
} 
demonstrar a centralidade da "agência" dos imigrantes para as migrações ${ }^{12}$. Há quem tente um equilíbrio entre estes fatores e há quem afirme que dada a complexidade dos processos migratórios, uma teoria geral que buscasse incluir a todos seria tão abstrata a ponto de não ter capacidade explicativa (CASTLES, 2007).

Grande parte dos estudos sobre migrações se dedica, neste sentido, à compreensão das dinâmicas que levam aos deslocamentos humanos. Ao longo dos anos, na literatura sobre o tema, diversos fatores se sucederam na preponderância ao explicar os deslocamentos. Inicialmente acreditava-se que a dinâmica das migrações obedecia à cálculos racionais de custo e benefício e maximização da utilidade. Era a tese da economia neo-clássica que fícou conhecida por buscar delimitar os fatores que estimulavam e desestimulavam os deslocamentos (push and pull factors), incluindo diferenças salariais, de oferta de trabalho, etc. (CASTLES; MILLER; 2009; CASTLES, 2004). Acreditava-se que as migrações equilibrariam essas diferenças.

Esta teoria, no entanto, não conseguiu explicar de forma satisfatória a dinâmica migratória. Os fatores que influenciavam as migrações eram mais numerosos e complexos, mesmo se considerados apenas os fatores econômicos. Hoje entende-se que o movimento de trabalhadores migrantes está inserido na dinâmica do capitalismo global, ou seja, uma dinâmica muito mais coletiva e não individual (CASTLES, 2003). Progressivamente, aos fatores econômicos e estruturais, se adicionaram os elementos políticos (determinados pelos Estados e suas legislações, não só regulatórios mas também de promoção de migração) e sociais (como as redes de migração que se estabelecem e facilitam a continuidade do processo migratório).

No Brasil, o caso dos imigrantes bolivianos ilustra essa complexidade. Eles aqui chegam, em geral, através de redes de familiares e amigos (que amiúde lhes financiam a viagem) para trabalhar em oficinas de costura improvisadas, onde em geral também residem, realizando jornadas de trabalho extenuantes e com baixa remuneração. Apesar da situação de exploração, muitos não aceitam ser tratados como vítimas de trabalho escravo ou tráfico (FREIRE DA SILVA, 2008). A imagem dos bolivianos como trabalhadores escravizados ou em situação análoga a de escravos é uma essencialização que os diferencia dos trabalhadores brasileiros, que supostamente, já teriam superado essa condição. Esta metáfora constitui um estigma que também nega a sua capacidade de ação autônoma manifestada na negociação do seu trabalho, ainda que mal remunerado, com diferentes empregadores (VIDAL, 2012) e na

\footnotetext{
${ }^{12}$ Sobre a "agência" dos imigrantes a respeito dos seus projetos migratórios, ver p. 19.
} 
sua busca individual por oportunidades de trabalho no Brasil. Tratados como vítimas e não como trabalhadores ou empreendedores, torna-se mais difícil o envolvimento dessas pessoas em pautas de reivindicação de direitos (DIAS e SPRANDEL, 2011) e a própria compreensão da exploração do seu trabalho.

Existem situações graves de violência e exploração em que está clara a configuração destes crimes $^{13}$. Cabe certamente uma discussão sobre a questão do trabalho digno, do rendimento justo, de um ambiente de trabalho seguro, da proteção social para si e seus familiares (OIT, 2006). Além disso, é imprescindível a problematização do funcionamento da cadeia produtiva do setor e das suas estratégias de exploração da mão de obra barata e, finalmente, a respeito da organização destes grupos para que se fortaleçam e façam frente à esta exploração (RIZEK; GEORGES; FREIRE DA SILVA, 2010).

A resposta estatal brasileira é a criminalização da exploração do trabalho dos imigrantes nas oficinas de costura em São Paulo, enquadrada pelo artigo 149 do Código Penal, e o fechamento dos locais onde, após fiscalizações que em geral decorrem de denúncias, constata-se a existência de condições degradantes de trabalho e de redução dos trabalhadores à condição análoga à de escravo (art. 149 do Código Penal). Além disso, resultam destas ações a aplicação de multas para os donos de oficina, a entrega de carteiras de trabalho para os trabalhadores e o pagamento de todos os seus direitos trabalhistas, em geral, pela grande loja que se encontra no início da cadeia de terceirizações. São ações que não atacam a estrutura do problema a qual está ligada a reorganização produtiva do setor nos anos 1990 no âmbito da expansão das políticas neoliberais que pediam redução drástica dos custos de produção. A informalidade da mão de obra e a terceirização na cadeia produtiva servem a este objetivo, e a mobilização da mão de obra migrante responde a esta necessidade. Um número muito maior de oficinas é aberto comparativamente ao número das que são fechadas. As grandes empresas que terceirizam a sua produção apenas substituem uma oficina pela outra e as oficinas chamam novos trabalhadores.

Durante as entrevistas realizadas para esta investigação, perguntado sobre a suficiência da resposta a este problema, o Entrevistado 03, ator governamental, reconhece que a questão é mais profunda, que é necessário reorganizar a cadeia produtiva por meio de pactos com as empresas, de redução dos níveis de terceirização, garantindo preços mínimos. O Entrevistado

\footnotetext{
${ }^{13}$ Ver ILLES, TIMÓTEO, FIORUCCI, 2008 e as diversas reportagens e pesquisas da ONG REPÓRTER BRASIL, fundada em 2001 com o "objetivo de fomentar a reflexão e ação sobre a violação aos direitos fundamentais dos povos e trabalhadores no Brasil", disponíveis no site reporterbrasil.org.br.
} 
05, também do governo, responde de forma mais ampla dizendo que a isso deve-se somar o acesso à cidadania, incluindo-se aí acesso a liberdades, serviços públicos, etc. O Entrevistado 13, conselheiro do CNIg, apesar de ter o tema em sua pauta de trabalho afirmou precisar refletir melhor sobre o assunto.

Como se vê, o capitalismo está de fato intrinsecamente ligado com as migrações. O capitalismo e a criação do trabalho assalariado que pôs fim à fixação do trabalhador à terra foram condição de possibilidade para as migrações. Por outro lado, as migrações em larga escala são um "lugar" de grande exploração e dominação atual. O trabalhador migrante, empobrecido e destituído de direitos é a mão de obra mais vulnerável à exploração capitalista. Basta observar a proliferação de sweatshops ${ }^{14}$ pelos diversos países do mundo para perceber que as migrações respondem hoje a uma dinâmica muito mais global do que a crises internas de países específicos (RIZEK; GEORGES; FREIRE DA SILVA, 2010).

Isto não significa dizer que os fatores objetivos dominam. Entende-se que o capitalismo, ao transformar as relações sociais, tornando-as abstratas, possibilitou que as pessoas pudessem deslocar-se em busca da reprodução de suas vidas. $\mathrm{O}$ fim da fixação à terra permitiu aos indivíduos a busca da reprodução de suas vidas em outros locais. Nesse quadro de relações sociais abstratas, a mediação das relações sociais entre os indivíduos e os governantes passou a ser realizada pelo direito agora também abstrato e potencialmente igualitário.

Da mesma forma que o direito, um instrumento auto-proclamado de igualdade, muitas vezes reproduz desigualdades, também a mobilidade, instrumento abstrato de igualdade, se desenvolve muitas vezes em um ambiente de exploração. Aí é que se coloca a luta dos imigrantes pela transformação das condições em que se desenvolvem as migrações, sem deixar de ter a clareza de que as condições que levam à decisão de migrar também são criadas pelo mesmo sistema de produção. Nesse sentido, a ideia de um direito de fuga (MEZZADRA, 2006), sem qualquer conotação jurídica, quer demarcar a dimensão subjetiva dos processos migratórios, notadamente, a subtração às condições econômicas, sociais e políticas do local de origem.

É lugar comum afirmar que a livre-circulação de bens e sobretudo de capitais ganha força com a globalização, enquanto a de pessoas é cada vez mais restrita. A descrição fática é correta, mas isso somente ilustra as contradições e a seletividade no processo de globalização

\footnotetext{
${ }^{14}$ Loja ou fábrica que explora os empregados com horas excessivas de trabalho, por baixos salários e em condições insalubres (RIZEK; GEORGES; FREIRE DA SILVA, 2010).
} 
e o que já se apontou sobre a migração e a cidadania como espaços de luta por liberdade e igualdade. As batalhas pela liberdade (instância cosmopolita ${ }^{15}$ ao interno das migrações) se confrontam com o imperativo do controle sobre o movimento do trabalho. Este imperativo central ao modo de produção capitalista é desafiado pela imprevisibilidade dos movimentos em forma de multidão (MEZZADRA, 2006; PAPASTERGIADIS, 2000; ARADAU; HUYSMANS, 2009). A imprevisibilidade, decorrente da autonomia que caracteriza estes movimentos hoje, é o que perturba os Estados e o mercado que gostariam de manter o controle sobre o movimento do trabalho.

Figura emblemática das contradições da globalização são as fronteiras que hoje se configuram como um campo de batalhas onde se luta por mobilidade-igualdade-liberdade, não somente em sentido metafórico, mas concretamente, com consequências sobre os corpos e sobre as vidas daqueles que lutam. As fronteiras se mostram cada vez mais superficiais em um mundo globalizado no qual todos são partícipes da produção da riqueza e da pobreza mundial (MEZZADRA, 2006).

No estudo das migrações busca-se, assim, captar também a redefinição destes dispositivos de dominação e exploração, e o conjunto de comportamentos e de práticas sociais que impõem um desafio radical à requalificação dos significados de igualdade e liberdade. As migrações, espaços de luta, não são vistas como prática emancipatória per se. Nos espaços transnacionais construídos pelos imigrantes, existem fragmentos do que poderia vir a ser um novo cosmopolitismo, mas também relações de dominação e exploração redefinidas (MEZZADRA, 2006).

Para Benhabib, cosmopolitismo é a preocupação com o mundo, como se fosse a sua própria polis. Inclui o direito à hospitalidade universal, "o que implica a compreensão de que cruzar fronteiras e buscar entrar em diferentes comunidades políticas não é um ato criminal, mas expressão da liberdade humana e da busca pelo desenvolvimento humano em um mundo que temos que compartilhar como nosso pares humanos" (BENHABIB, 2004). Nussbaum, por sua vez, defende que a política possa se sustentar em fundamentos de caráter mais internacional e lembra que o "nacionalismo e o particularismo etnocêntrico não são alheios um ao outro, mas afins". Por outro lado, afirma que o cosmopolitismo implica em "nos comprometer com o moralmente bom, que se pode recomendar como tal a todos os seres humanos" (NUSSBAUM, 1996), o que é objeto de grande crítica em razão da difículdade de

\footnotetext{
${ }^{15}$ No sentido da superação das diferenças de oportunidades e direitos em razão de ligações parciais como a nacionalidade etc., ou seja, o rechaço a diferenciações que não se sustentam frente à comum humanidade e que impedem os seres humanos de se desenvolver plenamente.
} 
delineamento desse parâmetro único ${ }^{16}$ sem que se dê lugar a hierarquizações e dominações culturais.

A abordagem da autonomia das migrações não se insere nem na corrente comunitarista, que prioriza a discussão identitária sem questionar a história da estrutura política das sociedades, nem na liberal que, ao defender o universalismo e a neutralidade da lei, também ignora os conflitos políticos anteriores a esta. As práticas dos imigrantes geram uma "tensão dentro do corpo social estruturado entre os que são parte e os que não são", revelando mais que exclusão a "violência original sobre a qual a sociedade e a política se regem" (MEZZADRA, 2006). Como proposta de pensamento crítico sobre a política, essa abordagem busca aprofundar o uso retórico dos direitos humanos bem como a análise simplificadora do universalismo. Propõe, no entanto, uma inversão da crítica aos que buscam mostrar que atrás da forma abstrata pode haver dominação. Quer-se, então, "descobrir naquela mesma forma abstrata os sinais de uma luta persistente pela sua ocupação" (MEZZADRA, 2006).

As migrações são um imenso laboratório de produção da diferença e

\footnotetext{
é no interior da nossa diferença que somos ao mesmo tempo mais potentes e mais vulneráveis; e algumas das tarefas mais difíceis de nossas vidas consistem justamente em reivindicar as diferenças e aprender a usá-las como pontes em lugar de barreiras entre nós. (LORDE apud MEZZADRA, 2011).
}

A avaliação que se faz das diferenças e das migrações não é romantizada nem estetizante. O capitalismo e a cidadania sempre funcionaram como máquinas de produzir diferenciações. O capitalismo serve-se deste expediente desde a diferenciação colonial até a precarização dos direitos dos trabalhadores, e a cidadania acompanha este processo, primeiramente definindo a linha que separava os nacionais dos estrangeiros, e hoje articulando os diversos níveis de direitos, curvando-se à variação da efetividade destes no plano interno, entre os próprios nacionais (MELLINO, 2013).

Este é o contexto no qual se investiga a hipótese do direito de fuga, que pode ser exemplificado pelo recente movimento migratório de haitianos para o Brasil. O país já extremamente pobre foi devastado por um terremoto de enormes proporções em 2010, que matou 300 mil pessoas e deixou um milhão e meio de desabrigados. Quatro anos após o

\footnotetext{
${ }^{16}$ No plano internacional, após o fim da Guerra Fria, nos anos 1990, desenhou-se um projeto de democracia cosmopolita que envolvia a expansão da democracia dentro dos Estados nacionais e também em nível global, no âmbito das instituições e foros internacionais. Cf. ARCHIBUGI, 2004. No plano interno dos Estados nacionais, este ideário tem justificado muitas guerras; no plano internacional, os avanços são tímidos.
} 
evento, cerca de 150 mil haitianos ainda vivem em barracas em condições extremamente precárias (QUATRO..., 2014). Cerca de $80 \%$ da população vive em situação de pobreza e apenas $20 \%$ dispõe de um salário estável (UNICEF, 2014) ${ }^{17}$. Em fuga dessa situação, muitos se deslocaram para países diversos da América (MAMED; LIMA, 2013) enfrentando diversas dificuldades e barreiras para migrar. Um país com pouco menos de 10 milhões de habitantes (UNICEF, 2014), tem a sua maior comunidade no exterior nos Estados Unidos, com cerca de 535 mil pessoas. Além dos Estados Unidos, os maiores deslocamentos de haitianos ocorriam no próprio Caribe, para a República Dominicana, Bahamas e para as Ilhas Turcas e Caicos britânicas (OIM, 2013), sempre de forma arriscada ou dificultada pelas legislações migratórias.

Em 2012, o número de imigrantes haitianos aumentou significativamente e gerou uma crise humanitária em pequenas cidades do Norte do país (MACHADO, 2012). Naquela época, após uma longa viagem, eles entravam pela fronteira Norte e solicitavam refúgio para obter documentação no país, a fim de buscar empregos em outras partes do país. O status de refugiado requerido pelos haitianos não foi reconhecido, mas o governo brasileiro criou um visto humanitário por meio da Resolução Normativa (RN) do CNIg n. 97 de 12 de janeiro de $2012^{18}$, tentando acabar com a rota de migração em curso - e a ação de supostos coyotes $^{19}$ ao estabelecer que o visto só poderia ser solicitado em Porto Príncipe. Esse objetivo não foi atingido e no início de 2013 houve nova crise humanitária na fronteira Norte (CONECTAS, 2013). A RN-CNIg n. 97/2012 foi então modificada pela RN-CNIg 102 de 26 de abril de 2013, que eliminou a quota de concessão de vistos estipulada em 1200 vistos por ano e a restrição de que os mesmos só pudessem ser emitidos na Embaixada brasileira em Porto Príncipe, permitindo que pudessem ser concedidos em qualquer representação do MRE.

Muito recentemente, o governo do Acre, de forma unilateral, decidiu encerrar as atividades do abrigo que mantinha com apoio financeiro do Governo Federal e, passou a financiar o transporte dos imigrantes haitianos que ali estavam até São Paulo (CONECTAS, 2014). A ação, realizada de forma precária, sem acompanhamento do destino destas pessoas e

\footnotetext{
${ }^{18}$ Dispõe sobre a concessão do visto permanente previsto no artigo 16 da Lei n. 6815 de 19 de agosto de 1980 a nacionais do Haiti.

19 Os chamados coyotes aproveitam-se das dificuldades para o atravessamento de fronteiras impostas pelas políticas migratórias e cobram dos imigrantes para ajudá-los a atravessá-las, fornecendo transporte, burlando os controles de fronteira ou subornando-os. O uso da expressão surgiu no México, onde é usada também para referir-se às pessoas que facilitam o encaminhamento de qualquer trâmite burocrático. No contexto mexicano é mais comum chamar de polleros aqueles que efetivamente atravessam as fronteiras com os imigrantes. Em inglês corresponde ao termo smugglers.
} 
sem aviso prévio às autoridades do Município e do Estado de São Paulo gerou uma emergência que atraiu a atenção da grande imprensa e dos altos escalões governamentais (RIBEIRO, 2014). Medidas de urgência para fornecer abrigo, alimentação e documentação para estas pessoas foram tomadas pela Prefeitura do Município de São Paulo (CRUZ, 2014; RIBEIRO, 2014a), e recentemente, em setembro de 2014, entrou em funcionamento o Centro de Referência e Acolhida para Imigrantes de São Paulo (CRAI-SP).

A situação econômica, política e social do Haiti, que oferecia poucas oportunidades de vida digna aos seus habitantes em razão de diversos fatores históricos, foi agravada em 2010 com a ocorrência do grande terremoto que atingiu a ilha. Em fuga de uma realidade deplorável, os haitianos intensificaram a busca, nos diversos países para onde migram, de oportunidades de trabalho para desenvolver suas vidas e sustentar suas famílias. No entanto, a fuga de desastres ambientais e da miserabilidade não são consideradas motivações para a concessão do status de refugiado, segundo a normativa internacional ${ }^{20}$. Sendo assim, os haitianos, como muitos outros migrantes, mobilizam os canais existentes de migração regular (reunião familiar, por exemplo) ou tentam superar os controles de fronteira para entrar e permanecer de forma irregular nos países de destino. A ligação estabelecida com o Brasil na última década em razão da presença da missão de paz comandada pelo Brasil (MINUSTAH) desde 2004, a emergência da economia brasileira e a existência de empregos no Brasil atraíram a atenção dos haitianos para o Brasil (MAMED; LIMA, 2013). Além disso, a construção da Rodovia Transoceânica criou uma ligação por terra entre a Amazônia brasileira e os países vizinhos com o intuito de intensificar as trocas comerciais e o acesso aos portos do Pacífico (MAMED; LIMA, 2013), mas também facilitou também o trânsito de pessoas; tudo isso somado à situação do país caribenho, estimulou a "fuga" dos haitianos para o Brasil. Sem estímulo governamental à imigração, a criação do visto humanitário foi um reconhecimento do "direito de fuga" e a tentativa de evitar maiores violações de direitos neste processo ${ }^{21}$.

A complexidade dos processos migratórios envolve, assim, questões econômicas e políticas difíceis de serem governadas (como o equilíbrio entre necessidade de mão de obra e

\footnotetext{
${ }^{20}$ Segundo a Convenção das Nações Unidas sobre o Estatuto dos Refugiados de 1951, são refugiados: " De acordo com a Convenção de 1951 relativa ao Estatuto dos Refugiados (de 1951), são refugiados as pessoas que se encontram fora do seu país por causa de fundado temor de perseguição por motivos de raça, religião, nacionalidade, opinião política ou participação em grupos sociais, e que não possa (ou não queira) voltar para casa. Posteriormente, definições mais amplas passaram a considerar como refugiados as pessoas obrigadas a deixar seu país devido a conflitos armados, violência generalizada e violação massiva dos direitos humanos". Cf. ACNUR. Agência da ONU para Refugiados. Perguntas e respostas. Quem pode ser considerado refugiado. Disponível em: http://www.acnur.org/t3/portugues/informacao-geral/perguntas-e-respostas/. Acesso em: 05 mai 2014.

${ }^{21}$ A efetividade desta medida será analista no ponto 2.2 .
} 
preocupações com a reação da opinião pública e grupos de interesse específico, por exemplo), mas também sociais (como as redes de migração que se estabelecem e contribuem à manutenção dos fluxos), e finalmente a própria agência ${ }^{22}$ dos imigrantes. Todos estes elementos influem na decisão de migrar, mas as decisões dos migrantes as excedem, ou seja, sublinha-se "o caráter irredutível dos movimentos migratórios contemporâneos às leis da oferta e da procura que governam a divisão internacional do trabalho" (MEZZADRA, 2006) e às leis e políticas instrumentalizadas a prover os mercados de trabalho com mão de obra flexível e/ou barata e descartável.

Focando nessas práticas de resistência e nas demandas subjetivas dos imigrantes que não se atêm às limitações impostas pelas políticas migratórias de entrada e controle de fronteiras, nem mesmo aceitam as classificações que as políticas e leis lhes impõe demonstrando a sua autonomia, esta abordagem promove uma reviravolta na visão sobre o processo, que quase sempre foi considerado a partir do ponto de vista dos Estados receptores $\left(\right.$ MEZZADRA, 2006) ${ }^{23}$. Um paradigma das migrações não só determina a tipologia das medidas políticas e das políticas públicas que serão estabelecidas como a própria estruturação do tratamento legal destas pessoas. Enquanto o paradigma nacionalista legitima a exclusão e a objetificação dos imigrantes, o paradigma da autonomia promove a inclusão e o reconhecimento da subjetividade dos imigrantes, ressignificando a cidadania.

Até tempos recentes o único ponto de vista considerado sobre as migrações era o do Estado nacional. Os Estados estabelecem critérios de seleção de imigrantes e regras de entrada em seu território. Contrariá-los era considerado uma violação por parte dos imigrantes. Hoje já há quem chame atenção sobre violações mais graves por parte do Estado decorrentes de suas políticas migratórias e de fronteiras contra os direitos humanos dos imigrantes (PÉCOUD, DE GUCHTENEIRE, 2006), questionando a legitimidade das barreiras à entrada. Os imigrantes assim, reivindicam a sua posição de sujeitos de direitos.

Reconhecer a subjetividade e a titularidade de direitos para os imigrantes é dar um passo a frente do histórico tratamento caritativo destinado aos imigrantes diante da vulnerabilidade e das privações enfrentadas (MEZZADRA, 2006). Apesar de sua importância para minimizar o sofrimento, o assistencialismo relega os imigrantes a uma condição passiva, incompatível com a condição de cidadão. É preciso considerar o ponto de vista dos

\footnotetext{
${ }^{22}$ Sobre a "agência" dos imigrantes a respeito dos seus projetos migratórios, ver p. 19.

${ }^{23}$ Há também na literatura trabalhos que, criticando a concentração das análises no ponto de vista dos Estados receptores, buscam analisar os movimentos migratórios do ponto de vista dos Estados de origem (Cf. PORTES, 2011). No entanto, continuam a tratar os imigrantes como peças em um tabuleiro e não como sujeitos de direito.
} 
imigrantes, a realidade das fronteiras porosas e o espaço transnacional que constituem; e articular esta compreensão ao seu protagonismo na busca de liberdade e de efetivação de seus direitos humanos, o que torna possível enxergar os imigrantes como sujeitos que incidem nas políticas migratórias de seus países de origem e de destino, verdadeiros atores das Relações Internacionais, que praticam a cidadania (WIHTOL DE WENDEN, 2013).

A entrada e a permanência de trabalhadores migrantes, independentemente de autorização nos territórios nacionais revela a interface do elemento de autonomia ou excedência dos movimentos em relação à política e às regras que buscam regular a entrada e a permanência dos imigrantes (baseada em critérios econômicos, culturais, geopolíticos ou de raça, gênero e classe). Da mesma forma, atuam em relação aos critérios para o reconhecimento da cidadania, uma vez que presentes no território, irregulares que sejam, os imigrantes praticam a cidadania ${ }^{24}$ (MEZZADRA, 2013; RIGO, 2011).

Existem dois níveis de análise sobre a prática da cidadania pelos imigrantes irregulares. Um deles apreende a condição de cidadania "irregular" e de inclusão pela mera presença física e realização de ações quotidianas. O outro nível de análise diz respeito à luta dos imigrantes por esse reconhecimento jurídico de sua condição e a transformação da própria cidadania para que a sua inclusão seja possível. Há quem queira ver somente no segundo tipo a prática de ações políticas (ISIN, 2008). No entanto, também os primeiros encerram uma conotação política pois decorrem de uma mobilidade não-autorizada em massa. São uma força pelo seu número diante das instituições políticas atuais que não os incluem (ARADAU; HUYSMANS, 2009)

Esta autonomia encerra em si desejos, expectativas e práticas subjetivas dos imigrantes. Nesse sentido, os movimentos migratórios não são vistos como meras respostas a problemas sociais e econômicos dos imigrantes, mas como uma força criativa no interior das estruturas sociais, econômicas e culturais (MEZZADRA, 2013). Estas práticas e demandas dos imigrantes revelam não somente os limites da política institucionalizada, mas também os

\footnotetext{
${ }^{24}$ Como se verá adiante, trata-se de uma concepção de cidadania diferente do tradicional, que se centra no conceito de status ao qual se ligam uma série de direitos dentro de um contexto jurídico e político previamente existente. Aqui valoriza-se o caráter dinâmico da cidadania, como um conceito em transformação (MEZZADRA, 2013) Veja-se a literatura tradicional: politicamente, no mundo moderno, a cidadania é o pertencimento a uma comunidade política (BENHABIB, 2004). Juridicamente, no Brasil, a cidadania é comumente caracterizada pela titularidade de direitos políticos de votar e ser votado. Segundo José Afonso da Silva, a cidadania é o atributo dos "participantes da vida do Estado, (...) pessoas integradas na sociedade estatal, atributo político decorrente do direito de participar no governo e direito de ser ouvido pela representação política". A nacionalidade é requisito para a cidadania, pois somente os nacionais brasileiros podem ser cidadãos; mas é mais ampla que esta pois nem todos os nacionais são cidadãos, somente aqueles que possuem os referidos direitos políticos (SILVA, J. A; 2005)
} 
limites do político. Em verdade, eles "pedem" uma "inclusão" que não pode ser satisfeita pelo atual sistema político, baseado na cidadania nacional e nas comunidades imaginadas homogêneas. Nesse sentido, a sua existência se liga às transformações globais (MEZZADRA, 2013). E aqui está o seu caráter político.

"A vontade-de-vida é a tendência originária de todos os seres humanos" e não o poder como dominação, como prescreve a Modernidade eurocêntrica. O conceito da vontade-deviver procura, ao contrário, a essência positiva do poder. "Poder empunhar, usar, cumprir os meios para a sobrevivência é já o poder”. [Assim], (...) a política é uma atividade que organiza e promove a produção, reprodução e aumento da vida de seus membros" (DUSSEL, 2007).

É objeto de preocupação na literatura essa passagem da observação e análise sociológica do transnacionalismo nas migrações para uma leitura das consequências políticas deste. Durante muito tempo, diversos pesquisadores se dedicaram à pesquisa empírica deste processo nas migrações, sem no entanto, tirar conclusões políticas a respeito. Apesar disso, a política é atingida na sua base por esses processos. Tal clareza resulta da necessária conexão destas conclusões com a teoria social - e, assim, a contestação das narrativas contraditórias que se constroem sobre o imigrante: criminoso, invasor, talento ou profissional necessário, vítima, esperança de desenvolvimento dos países de origem, etc. supera o nacionalismo metodológico (GLICK SCHILLER, 2009) — para enxergar nesses movimentos uma potência de transformação da democracia global. Em um âmbito onde se debate incessantemente a mudança de escala das instituições globais, as migrações trazem uma faísca para mudança que não está centrada na expansão, mas na transformação das instituições nacionais em resposta aos processos transnacionais e globais, em especial, da cidadania (ARADAU; HUYSMANS, 2009).

O reconhecimento do caráter político das migrações é também abertura para a subjetivação dos imigrantes (MEZZADRA, 2006). Ao analisar a figura do migrante desta forma, destaca-se a força da sua ação e a busca de liberdade que o seu movimento encarna, colocando também à mostra as técnicas de poder mobilizadas (cidadania nacional, racismo, colonialismo) a serviço de novas formas de exploração e dominação. Assim, é importante ressaltar que o migrante submetido a estas condições toma uma decisão custosa. $\mathrm{O}$ impacto sobre a sua vida é profundo, o que o diferencia do cidadão pós-nacional ideal (NUSSBAUM, 1996), sujeito pós-moderno sem raízes (MEZZADRA, 2006) em um sistema político pós- 
nacional $1^{25}$. Os espaços transnacionais que constrói são espaços de lutas e de adaptação, não sem dificuldades.

O transnacionalismo, então, representa uma importante mudança de escala que serve a dar visibilidade à agência ${ }^{26}$ dos migrantes e à qual necessita-se incorporar esta leitura política dos movimentos. Os Estados nacionais, no entanto, ao construir as suas políticas, classificam os diferentes movimentos migratórios em legítimos e ilegítimos (regulares e irregulares) a partir dos seus interesses. As lutas em torno da irregularidade é que reconstituem a política, e os conceitos de irregularidade e fronteira agregam outros elementos à ideia de escala, mais descritiva, para pensar a política de forma mais dinâmica (SQUIRE, 2011).

A deslegitimação de determinados movimentos migratórios não se faz meramente por regras, que serão melhor analisadas nas próximas seções. Esta política é bem mais profunda e passa por construções mentais e simbólicas. A construção da pauta internacional do tráfico de pessoas é bastante ilustrativa neste sentido. Dentre as diversas questões ligadas ao tema da mobilidade humana, o tráfico de pessoas é a que, atualmente, encontra-se no topo da agenda de prioridades da comunidade internacional. Já existiam instrumentos pontuais de enfrentamento ao tráfico desde o início do século XX (CASTILHO, 2008), mas foi na década de 1990 que o tema ganhou nova força sobre impulso dos países desenvolvidos (JAHIC; FINCKENAUER, 2005), a mesma época em que a migração se torna uma pauta sensível nestes países ${ }^{27}$. Em 1998, foi constituído um Comitê intergovernamental na Organização das Nações Unidas (ONU) para elaboração de uma Convenção Internacional contra o Crime Organizado Transnacional e, caso fosse pertinente, outros instrumentos relativos ao tráfico de mulheres, crianças, armas de fogo e imigrantes (Resolução da AG n. 53/11 de 9 de dezembro de 1998). Dois anos após a constituição deste Comitê, as negociações se encerraram e o chamado Protocolo de Palermo (o Protocolo Adicional à Convenção das Nações Unidas contra o Crime Organizado Transnacional Relativo à Prevenção, Repressão e Punição do Tráfico de Pessoas, em Especial Mulheres e Crianças) foi aprovado. Este Protocolo entrou em

\footnotetext{
${ }^{25}$ Sassen diferencia a cidadania pós-nacional e cidadania não-nacional. A primeira diz respeito à construção de novos níveis de institucionalidade política ou de atuação política, além do Estado nacional, onde estes cidadãos exercem seus direitos. A segunda diz respeito às transformações que atingem o instituto dentro do próprio Estado. SASSEN, 2006.

${ }^{26}$ Sobre a "agência" dos imigrantes a respeito dos seus projetos migratórios, ver p. 19.

${ }^{27}$ Em 2000, os EUA aprovaram uma nova legislação interna, o Trafficking Victims Protection Act (TVPA), que prevê, entre outras, sanções unilaterais para os países que, segundo os seus critérios, não se empenharem no enfrentamento do tráfico de pessoas. As sanções unilaterais preveem a retirada de assistência não humanitária e não relacionada ao comércio de países que não estiverem cumprindo os padrões mínimos de combate ao tráfico de pessoas estabelecidos pelos EUA. Anualmente, os EUA publicam o relatório Trafficking in Persons Report (TIP Report) com essa avaliação. Esta normativa foi atualizada em 2003, 2005 e 2008.
} 
vigor cerca de três anos após a sua adoção, em 25 de dezembro de 2003 e hoje são 159 os seus Estados partes ${ }^{28}$.

No que diz respeito ao debate interno conceitual, a despeito da consolidação de uma definição deste crime no Protocolo de Palermo ${ }^{29}$, persistem várias divergências. Para este estudo interessa sobretudo a que se refere à extensão do campo de situações em que o potencial migrante será tratado como sujeito capaz de tomar a decisão de imigrar. À época das negociações destes instrumentos internacionais, assim como hoje, o debate se confundia muito com o debate sobre a prostituição (BARALDI; VENTURA, 2013). Notadamente as posições se polarizavam entre aqueles que consideravam a exploração inerente à prostituição, e os que consideravam que são outros os elementos relativos à liberdade/coerção e condições de trabalho que determinam a existência de exploração. Esta última posição foi vencedora, exigindo-se a configuração destes elementos de coação ou engano para a caracterização do crime envolvendo adultos. Apesar disso, com o expediente de centrar o debate internacional sobre a mobilidade no combate ao crime, desloca-se a questão da mobilidade para o âmbito criminal de combate ao tráfico e consegue-se diminuir a subjetividade dos sujeitos imigrantes. Aqueles que não são traficados (vítimas) são migrantes econômicos não autorizados (crescentemente criminalizados).

A questão da oferta de trabalho e da necessidade de mão de obra é, assim, conjugada à luta contra imigração irregular. Desta forma, as propostas dos países de destino dos imigrantes são construídas a partir da necessidade de uma política migratória mais flexível que esteja alinhada com as demandas do mercado de trabalho e que ao mesmo tempo dê suporte à integração e enfrente a imigração ilegal ${ }^{30}$, ou seja, controle a imigração segundo os interesses

\footnotetext{
${ }^{28}$ Ver: https://treaties.un.org/. Consulta em 04 mai 2014.

${ }^{29}$ Artigo 3. Definições. Para efeitos do presente Protocolo: a) A expressão "tráfico de pessoas" significa o recrutamento, o transporte, a transferência, o alojamento ou o acolhimento de pessoas, recorrendo à ameaça ou uso da força ou a outras formas de coação, ao rapto, à fraude, ao engano, ao abuso de autoridade ou à situação de vulnerabilidade ou à entrega ou aceitação de pagamentos ou benefícios para obter o consentimento de uma pessoa que tenha autoridade sobre outra para fins de exploração. A exploração incluirá, no mínimo, a exploração da prostituição de outrem ou outras formas de exploração sexual, o trabalho ou serviços forçados, escravatura ou práticas similares à escravatura, a servidão ou a remoção de órgãos; b) O consentimento dado pela vítima de tráfico de pessoas tendo em vista qualquer tipo de exploração descrito na alínea 'a' do presente Artigo será considerado irrelevante se tiver sido utilizado qualquer um dos meios referidos na alínea 'a'; c) O recrutamento, o transporte, a transferência, o alojamento ou o acolhimento de uma criança para fins de exploração serão considerados "tráfico de pessoas" mesmo que não envolvam nenhum dos meios referidos da alínea 'a' do presente artigo (...).

${ }^{30}$ Em 2005 a Europa lançou o Global Approach to Migration and Mobility (GAMM) e em 2011 apresentou a segunda fase das diretrizes de trabalho para o tratamento das migrações em suas relações com países terceiros (COM (2011) 743) que inclui a ênfase na importância de um impulso a uma migração bem gerenciada de países de fora da União Europeia. No relatório de 2014, aponta-se que ainda não se fez uso de toda a potencialidade dos instrumentos desenvolvidos sob o GAMM para que as migrações possam servir a enfrentar as situações de falta de mão de obra em geral e de mão de obra especializada em determinados setores. No documento de 2011 se
} 
dos Estados.

Estas discussões não são apenas conceituais, pois a reconfiguração das relações entre fronteiras, identidades e ordem político-jurídica reflete-se em políticas, estruturas legais e no imaginário nacional. Entre as questões práticas que se ligam a esta tríade estão algumas relativas ao pertencimento, valores morais e políticos; territorialidade, admissão, condição migratória regular e deportação; soberania, direitos e deveres (VERTOVEC, 2004), daí a importância desta discussão ao se pensar uma política migratória concreta. A continuidade do nacionalismo metodológico que faz corresponder fronteiras estatais a fronteiras sociais (VERTOVEC, 2004), continua a tratar o imigrante como uma ameaça.

\subsection{Irregularidade migratória: migração-problema e migração-negócio}

A irregularidade ou "ilegalidade" migratória, comumente é entendida como o status legal daquele que entra no território de um país sem autorização ou que ali permanece após o vencimento de sua autorização. Também pode incluir aqueles que, em seu quotidiano, não atendem aos termos de sua estadia. Por exemplo, aqueles que detém um tipo de registro que não os permite trabalhar - como é no Brasil o caso dos estudantes - e mesmo assim trabalham, podendo perder sua autorização para aqui permanecer a qualquer tempo, caso esta situação seja descoberta. Por conseguinte, são forçados a estabelecer relações informais de trabalho.

Existem diversas formas de referir-se a esta situação ilegalidade: irregularidade, indocumentação. A primeira delas simboliza o processo de criminalização das migrações que será analisado, utilizando-se esta expressão apenas para a sua problematização e entre aspas, para marcar o seu simbolismo. A irregularidade expressa o resultado da aplicação da legislação migratória a estes casos, ou seja, expressa o fato que o descumprimento da legislação migratória consiste em uma infração administrativa. O mesmo se pode dizer do termo indocumentação que, no entanto, centra-se mais na situação fática da ausência de documentos do que na relação da conduta do indivíduo com a lei. Prefere-se o uso deste último termo, uma vez que discute-se aqui justamente os contornos dos institutos jurídicos 
que dão lugar às regras que geram a indocumentação, mas os demais termos serão utilizados quando as situações que descrevem forem o foco da discussão.

Em alguns casos, no entanto, a ilegalidade ultrapassa o simbólico e cristaliza-se na lei. Na Itália, em 2009, a imigração clandestina (ou sem autorização) tornou-se infração penal. O parágrafo 16 do primeiro artigo da Lei 94/2009 que modificou o decreto legislativo n. 286 de 25 de julho de 1998, testo unico delle disposizioni concernenti la disciplina dell'immigrazione e norme sulla condizione dello straniero, inseriu o art. 10 bis neste decreto. Intitulado "Ingresso e permanência ilegal no território do Estado" o artigo dispõe: Art. 10 bis, decreto legislativo n. $286 / 98^{31}$

\begin{abstract}
Salvo se o fato constituir infração penal mais grave, o estrangeiro que ingressa ou permanece no território do Estado, em violação das disposições do presente texto único, além das previstas no art. 1 da Lei n. 68 de 28 de maio de 2007 (que disciplina a permanência de breve duração dos estrangeiros para visita, negócios, turismo e estudo), é punido com multa de 5.000 a 10.000 euros. Ao presente crime não se aplica o artigo 162 do código penal (que prevê a extinção do crimes punidos com multa somente, caso haja o pagamento de um terço do valor máximo da pena antes do decreto de condenação) (livre tradução e grifo da autora).
\end{abstract}

Recentemente, o Parlamento italiano aprovou a Lei 67/14 de 28 de abril de 2014 que delega ao Poder Executivo a emanação de um Decreto Legislativo em até 18 meses para descriminalização de uma série de infrações penais, entre elas o de imigração clandestina (ITALIA, 2014). A medida foi muito criticada pelo partido nacionalista e xenófobo Lega Nord. Os argumentos a favor da aprovação, no entanto, incluíam a inutilidade e ineficácia de tal medida, uma vez que não facilitou a realização das expulsões e abarrotou o Judiciário com cerca de 200 mil processos que até hoje esperam julgamento (ADUC, 2014; PANORAMA, 2014).

A tipificação penal da conduta é exceção, talvez porque, de fato, não atenda aos objetivos dos Estados, o que não impede que se promova a sua criminalização social, como se verá. De forma geral, as regras de admissão de migrantes variam consideravelmente a depender da conjuntura econômica e política. Sabe-se que as políticas migratórias variaram muito ao longo da história dos diferente países, passando por momentos de atração, situações de fechamento para a saída, fechamento para a entrada, abertura ou fechamento para

\footnotetext{
${ }^{31}$ Texto original: "Salvo che il fatto costituisca più grave reato, lo straniero che fa ingresso ovvero si trattiene nel territorio dello Stato, in violazione delle disposizioni del presente testo unico nonché di quelle di cui all'articolo 1 della legge 28 maggio 2007, n. 68, è punito con l'ammenda da 5.000 a 10.000 euro. Al reato di cui al presente comma non si applica l'articolo 162 del codice penale".
} 
determinados grupos que podem ter sido de determinadas profissões, de determinada origem étnica, etc. Assim, a irregularidade não é uma situação ligada a uma condição substantiva do imigrante. Esta condição resulta, isto sim, das decisões políticas do Estados que consideram os imigrantes apenas como objetos de suas políticas - mão de obra descartável para as necessidades do seu mercado - em contraposição às ações dos migrantes que são protagonistas destes movimentos e aí exercem sua subjetividade.

As regras jurídicas estabelecidas para a migração (nacionais, bilaterais e/ou regionais), assim, geram resultados muito relevantes, não para evitar a imigração, como se verá, mas para determinar as condições em que esse deslocamento ocorrerá. Determinam se a migração poderá ocorrer de forma regular, e se o migrante será classificado como trabalhador, familiar, estudante, refugiado, etc.. Caso perca o trabalho, não "será" mais trabalhador e deverá deixar o país; caso se divorcie não "será" mais familiar e também deverá abandonar a sua vida no país. Os desejos e as mudanças que fazem parte da dinâmica da vida não cabem nestas regras migratórias cujo horizonte é a irregularidade.

Além disso, estas regras influenciam também a forma de deslocamento. Diante do cenário de barreiras físicas e jurídicas que se apresenta, o indivíduo poderá decidir buscar o serviço de coyotes para conseguir cruzar fronteiras cada vez mais fechadas e vigiadas. Nesses casos, terá ainda mais chances de ser envolvido em redes de tráfico de pessoas, que são as maiores beneficiárias da dificuldade para migrar.

Em um campo mais simbólico, a política migratória de cada país estabelece uma linha de separação entre movimentos legítimos e ilegítimos e esta avaliação decorre uma hierarquização moral destes movimentos, operacionalizada por uma uma abstração legal determinante (DE GENOVA, 2002). A variabilidade da condição da irregularidade responde à entrada ou saída de determinado movimento da mira do controle (SQUIRE, 2011), da mesma forma que ocorre com os cidadãos, através de outros mecanismos. Portanto, em razão da historicidade das configurações de "ilegalidade" há quem afirme que não se possa falar de uma experiência migratória genérica (DE GENOVA, 2002). Um dado não exclui o outro (MEZZADRA, 2006), afinal, se é certo que a ilegalização serve a um objetivo e destinatários $\operatorname{concretos}^{32}$, também é certo que todos podem, com maior ou menor probabilidade,

\footnotetext{
32 De Genova mostra como o novo problema social do imigrante ilegal foi construído nos Estados Unidos a partir da década de 60 para os mexicanos. Além da revisão das leis nesse sentido, uma série de instrumentos simbólicos foram utilizados para que estes fossem reconhecidos como os imigrantes ilegais. Uma série de instrumentos de securitização foram estabelecidos, nunca suficientes para barrar totalmente a sua entrada, enquanto a deportabilidade os vulnerabilizava, submetendo-os a todos os níveis de exploração e obediência no trabalho (2002).
} 
potencialmente ocupar essa posição.

Os contornos das atuais políticas migratórias nacionalistas/lizadas, de forma geral, servem então para colocar os imigrantes naquela situação ambígua de grande vulnerabilidade - a partir da centralidade das políticas migratórias na irregularidade - e ao mesmo tempo de força, ao questionar o sistema, estabelecendo-se no território estrangeiro a despeito das regras nacionais. Nesse sentido, é possível afirmar que, em certa medida, as políticas migratórias criam muitos dos problemas que dizem buscar evitar (imigração irregular, exploração de mão de obra, violações de direitos dos imigrantes, conflitos sociais) ao ignorar e operar segundo uma lógica diversa à dinâmica autônoma e aos desejos e ações dos indivíduos migrantes.

As políticas dos Estados Unidos e da União Europeia ${ }^{33}$ encaixam-se nessa descrição (SQUIRE, 2011). Na União Europeia, em uma tentativa de manutenção de seus princípios humanistas, o discurso dos direitos humanos é livremente mobilizado, inclusive os direitos humanos dos próprios migrantes. A narrativa construída é a de que ao impedir que os migrantes entrem em seu território, a União Europeia os estaria protegendo ${ }^{34}$. A ideia do risco e da crise contribuem para que o esforço da política seja apresentado como humanitário e não como policialesco. Os discursos mobilizam a ideia de que os jovens precisam continuar nos seus países para desenvolvê-los, falam em tratamento justo, devido processo e dignidade das pessoas (FELDMAN, 2012). O mesmo vale para os discursos sobre migração e desenvolvimento que incluem o tema da necessidade da permanência e contribuição dos migrantes aos seus países de origem ${ }^{35}$.

Essas políticas não somente resultam no incremento da imigração irregular, mas tem a irregularidade como conceito chave (SQUIRE, 2011). Com esse expediente, criam um problema social, fundamentam a criminalização dos movimentos e justificam a securitização das fronteiras e a expansão dos controles internos. A criminalização da migração toma forma

\footnotetext{
${ }^{33}$ No que se refere à União Européia, apesar de se tratar de um ente regional supranacional, o nacionalismo metodológico continua a operar. Não somente porque a competência para admissão de migrantes de países de fora da União continua a pertencer aos Estados, como também porque a política comum sobre cidadania e sobre fronteiras apenas amplia o alcance do critério nacional, sendo excludente aos nacionais dos países de fora da União e ainda excepciona alguns direitos do cidadão europeu com base no critério nacional. Este tema será abordado na seção 2.1.2.

${ }^{34}$ No ponto 36 da conclusões do Conselho Europeu de 18 e 19 de junho de 2009, afirma-se: "Os recentes acontecimentos em Chipre, Grécia, Itália e Malta sublinham a urgência do redobrar de esforços para prevenir e combater eficazmente a imigração ilegal nas fronteiras marítimas do Sul da UE de modo a evitar futuras tragédias humanas". A tragédia de Lampedusa em outubro de 2013 que deixou cerca de 300 mortos atraiu a atenção internacional para uma tragédia que é quotidiana. Segundo o blog Fortress Europe que compila notícias sobre os naufrágios de barcos com imigrantes no Canal da Sicília, de 1994 a outubro de 2013 ocorreram 7.065 mortes nesta travessia entre a África e a Europa (NEL CANALE..., 2013)

${ }^{35}$ Ver seção 1.3 .
} 
através da sua associação com temas securitários como o terrorismo e o tráfico de pessoas, e pelo recurso à prisões e detenções de imigrantes, ainda que administrativas. Daí resultam menores garantias aos acusados (DELMAS-MARTY, 2013), além de generalizações e da associação da coletividade dos imigrantes ou de alguns grupos deles ao cometimento de delitos, o que reduz a sua individualidade e integra a exigência de provas de lealdade e correção imposta aos que vem "de fora". Na Europa, cúpulas como as de Dublin, Sevilha ou Tessalônica, e os textos que delas resultaram, tratam o "risco migratório" e os "clandestinos" implicitamente criminalizados por meio dos mesmos dispositivos que servem à prevenção do terrorismo (WEBER, 2009).

A securitização, como uma tecnologia política transversal, é usada para lidar com o que incomoda, ao considerar que o Estado delimita as fronteiras da corpo político e da percepção crescente da incapacidade deste controlar estas fronteiras e outras questões, reafirmando a sua importância para a proteção de seus cidadãos (BIGO, 2002). Explica-se, por conseguinte, a crescente restritividade, controle e criminalização entre os países receptores de imigração.

Na Europa, o Programa de Estocolmo estabelece as prioridades para a área de justiça, liberdade e segurança para o período de 2010 a 2014, intitulado "Uma Europa aberta e segura que sirva e proteja os cidadãos". Ao tratar das prioridades políticas da área afirma-se:

\begin{abstract}
O desafio consistirá em assegurar o respeito das liberdades fundamentais e da integridade e ao mesmo tempo garantir a segurança na Europa. É de capital importância que as medidas repressivas e as medidas de salvaguarda dos direitos pessoais, do Estado de direito e das regras relativas à protecção internacional tenham uma orientação idêntica e se reforcem mutuamente. A acção futura deverá, portanto, centrar-se nos cidadãos e noutras pessoas relativamente às quais a União tem responsabilidades [...] (UE, 2010).
\end{abstract}

E entre as prioridades, elenca:

\begin{abstract}
Acesso à Europa num mundo globalizado (grifado no original): $O$ acesso à Europa para empresários, turistas, estudantes, cientistas, trabalhadores, pessoas necessitadas de protecção internacional e outras que tenham um interesse legítimo no acesso ao território da União (grifo nosso) tem de ser tornado mais efectivo e eficiente. Ao mesmo tempo, a União e os seus Estados-Membros têm de garantir a segurança dos seus cidadãos. A gestão integrada das fronteiras e as políticas de vistos deverão ser concebidas de modo a servir estes objectivos (UE, 2010).
\end{abstract}

O discurso do gerenciamento da migração e do triple win game ${ }^{36}$ já aparece, mas o

\footnotetext{
${ }^{36}$ Serão analisados na seção 1.3 .
} 
combate à imigração "ilegal" não perde a sua centralidade com o advento desta nova estratégia discursiva. No Plano de Ação do Programa de Estocolmo afirma-se:

\begin{abstract}
A UE deve esforçar-se por atingir um nível uniforme de direitos e obrigações para os imigrantes legais, comparável ao dos cidadãos europeus. A consolidação destes direitos num código da imigração e a adopção de regras comuns que permitam gerir eficazmente o reagrupamento familiar são essenciais para maximizar os efeitos positivos da imigração legal a favor de todas as partes interessadas, reforçando assim a competitividade da União. A integração dos migrantes prosseguirá, sendo protegidos os seus direitos e igualmente sublinhadas as suas próprias responsabilidades quanto à integração nas sociedades onde vivem.

A prevenção e a redução da imigração ilegal em consonância com a Carta dos Direitos Fundamentais são igualmente importantes para a credibilidade e o sucesso das políticas da UE neste domínio. Será dada especial atenção à situação das crianças não acompanhadas (UE, 2010).
\end{abstract}

No entanto, ao elencar as ações, prevê-se uma série de medidas repressivas e de facilitação de deportações, além de sanções contra empregadores que finalmente revertem contra os próprios imigrantes. Além disso, o Programa inclui ações relativas ao combate ao terrorismo, contra o tráfico de drogas e outros diversos tipos de criminalidade, tráfico de pessoas, exploração sexual, crimes econômicos, corrupção, juntamente com ações relativas à política de vistos, de asilo, de migração e desenvolvimento, migração e trabalho e direitos dos imigrantes, que se restringem ao reagrupamento familiar.

Nesse sentido, não importa a quantidade de estudos que demonstrem que estas associações que sustentam o discurso securitário não se sustentam em dados empíricos ${ }^{37}$, que as políticas securitárias não são efetivas (BIGO, 2002), que se tenha pouco conhecimento confiável sobre o próprio volume da presença de imigrantes indocumentados, ou ainda que se saiba que a sua presença é mínima, como ocorre no Brasil, um país de 200 milhões de habitantes em que a chegada de 2000 haitianos foi noticiada como "invasão" ${ }^{38}$. A centralidade que assume a "ilegalidade" nas políticas de migração também é justificativa para expandir o controle sobre todos os sujeitos (DE GENOVA, 2002; BIGO, 2011). Em nome da segurança, proliferam-se os controles e a vigilância tendencialmente onipresente: vistos digitais, sistemas de autorização pré-viagem, bancos de dados compartilhados, e controles da situação migratória permanentes e reiterados, que promovem uma multiplicação das zonas de fronteira

\footnotetext{
${ }^{37}$ Há pouco conhecimento, por exemplo, sobre a extensão e o impacto da imigração irregular. No Brasil o percentual de imigrantes regulares é de cerca de $0,3 \%$ da população. Mesmo sem estimativas confiáveis, é certo que o de irregulares é muito menor do que o de regulares, sobretudo após os Acordos de Residência do Mercosul. Sobre os Acordos de Residência, ver p. 92.

${ }^{38}$ Ver, por exemplo, THOMAZ, 2012. VENTURA; ILLES, 2012.
} 
e um redesenho da liberdade (BIGO, 2011; SQUIRE, 2011).

O foco no combate ao crime divide os atores da migração não-autorizada entre criminosos e vítimas. O discurso se divide, mas na verdade ambos são indesejados e objetos da mesma política excludente. Há quem considere importante a distinção entre políticas de migração e políticas de controle (SQUIRE, 2011). Esta separação pode sim ser interessante no sentido de verificar quem são os sujeitos e os objetos da migração e do controle. Está claro que sujeitos das migrações são os próprios migrantes e sujeitos do controle são os Estados. As políticas de migração dos Estados, no entanto, são operacionalizadas por intermédio das políticas de controle. Os migrantes são sujeitos desse movimento, ainda que a eles não seja dada voz na definição das políticas migratórias dos Estados. É onde se estabelecem as lutas e a sua incidência política, inclusive em torno do conceito de irregularidade.

Na equação entre tráfico de pessoas e exploração do trabalho, enfatiza-se o combate ao primeiro de forma descontextualizada. Isso implica que a questão a ser enfrentada refere-se à mobilidade, segurança e combate ao crime. As estratégias de exploração do trabalho no sistema capitalista que envolvem os sujeitos migrantes ficam invisibilizadas e os migrantes são culpabilizados pelo problema. Além disso, na construção da definição do tráfico, pouco foram consideradas as percepções das próprias vítimas ou pessoas envolvidas (PISCITELLI, 2008), provavelmente porque elas são menos vitimizantes do que o necessário para justificar o paradigma securitário.

Além das fronteiras, lugar em que a "ilegalidade" torna-se visível através da imagem da perda de controle, o que justifica a sua securitização e militarização, outras estratégias de "ilegalização" atingem os migrantes: a precarização de todas as formas de migração regular e o esvaziamento de categorias protetivas, como o refúgio. Na Europa hoje, a celeuma criada em torno da imigração "ilegal" leva à construção de justificativas para a violação até mesmo de princípios consolidados como o do non-réfoulement para os refugiados ${ }^{39}$.

O instituto do refúgio é regido por princípios, normas e regras bem definidas em acordos internacionais amplamente reconhecidos, dentre os quais se destaca o princípio da proibição de expulsão ou repulsão (non-réfoulement) que afirma que "nenhum dos Estadosmembros expulsará ou rechaçará, de maneira alguma, um refugiado para as fronteiras dos territórios em que a sua vida ou a sua liberdade seja ameaçada em virtude da sua raça, da sua religião, da sua nacionalidade, do grupo social a que pertence ou das suas opiniões políticas" (Art. 33 da Convenção das Nações Unidas relativa ao Estatuto dos Refugiados de 1951). Nos

\footnotetext{
${ }^{39}$ Sobre este tema ver, por exemplo, Decisão do Conselho de Estado Francês. FRANCE, 2012.
} 
últimos anos, este princípio fundador tem sofrido inúmeras violações por parte dos Estados ocidentais que patrocinaram a sua criação, juntamente com o movimento de afirmação internacional dos direitos humanos no pós Segunda Guerra Mundial ${ }^{40}$.

Os conflitos na África e na Ásia, sobretudo, mas também na América Latina e Europa, obrigam milhares de pessoas a deixarem suas casas todos os anos. A grande maioria permanece em campos de refugiados que são lugares precários, por anos, à espera de um dia poder retornar às suas cidades. Uma pequena parcela deste grupo consegue e/ou decide buscar proteção em outros países. Entre estes, um pequeno número é reassentado através dos programas do Alto Comissariado das Nações Unidas para os Refugiados (ACNUR) que negocia a recepção destes em outros países e lhes garante apoio até a sua inserção na nova sociedade. Outra parte dos refugiados internacionais muitas vezes se submete a viagens longas, perigosas e incertas, tentando atingir o território estrangeiro para, baseados no princípio do non-réfoulement, demandar o reconhecimento do status de refugiado. Muitas dessas viagens, no entanto, não são bem-sucedidas e, vistas de perto, são roteiros da busca desesperada pela sobrevivência. Em 2012, o ACNUR calculava a existência de 15,4 milhões de refugiados (2/3 seu mandato, e 1/3 sob mandato da Agência das Nações Unidas de Assistência aos Refugiados da Palestina - UNRWA), além de 28,8 milhões de deslocados internos, e quase um milhão de solicitantes de refúgio (ACNUR, 2012).

No final de 2012, 81\% dos refugiados residia nos países em desenvolvimento (ACNUR, 2012). Com o término da Guerra Fria diminuiu o interesse político e ideológico contido na ideia de proteção e acolhimento aos refugiados do ex-bloco Comunista que deu origem à Convenção sobre o Refúgio de 1951, posteriormente estendida a outras situações com o Protocolo de 1967 relativo ao Estatuto dos Refugiados ${ }^{41}$. Hoje a maior parte dos

\footnotetext{
${ }^{40}$ A Líbia, país para onde são direcionados os barcos que as patrulhas italianas conseguem interceptar, não é parte da Convenção de Genebra de 1951 sobre o Estatuto dos Refugiados nem do Protocolo que o complementa de 1967. É parte da Convenção Africana sobre refugiados, mas não possui instrumentos de proteção efetiva dos refugiados, conforme revela o relatório da Human Rights Watch, intitulado "Pushed Back, Pushed Around: Italy's Forced Return of Boat Migrants and Asylum Seekers, Libya's Mistreatment of Migrants and Asylum Seekers" (2009). As violações realizadas e permitidas pelo regime de Gheddafi à época eram denunciadas há anos, o que não impediu a Itália de negociar com este país diversos acordos com vistas ao patrulhamento e devolução de cidadãos africanos que tentam chegar à Itália em embarcações extremamente precárias. Essa política de externalização do direito de asilo não é nada mais do que uma manobra para fechar a Europa também para os demandantes de asilo ou outras formas de proteção internacional; proteção que a Europa reconhece e muitos países de trânsito dos imigrantes em direção à Europa, como é o caso da Líbia. Esta negação da proteção internacional vem sendo denunciado tanto pelo ACNUR como por organizações humanitárias como os "Médicos sem fronteiras". HYNDMAN e MOUNTZ (2008) chamam de neo-refoulement esta nova estratégia baseada na geografia que finalmente muda a abordagem dos instrumentos internacionais sobre o refúgio para a abordagem do gerenciamento das migrações, preferencialmente nas regiões de origem. A Europa, em diversos documentos como o Pacto Europeu sobre migrações e asilo e a o Programa de Estocolmo (2009-2014), advoga estas medidas. ${ }^{41}$ Assinado em Nova Iorque em 31 de janeiro de 1967. Entrou em vigor em 4 de outubro de 1967.
} 
refugiados provém dos países do chamado terceiro mundo e há uma tentativa de "desconstrução fática" do instituto por meio do "mito da diferença" que, ao ressaltar as diferenças entre os fluxos de refúgio do período da Guerra Fria e os posteriores, busca justificar a rejeição e as barreiras aos "novos refugiados" no território europeu (CHIMNI, 1998).

Há um problema no esvaziamento das categorias protetivas, mas há também um problema na afirmação de suas diferenciações. As interações complexas e as linhas tênues que separam as realidades migratórias são pouco trabalhadas. Em geral, as classificações sobre a mobilidade têm servido grandemente à sua limitação. A macrodiferenciação existente referese às migrações voluntárias e forçadas, ou migrações econômicas e refúgio. Impõe-se, conforme já referido, uma hierarquização moral entre as motivações ${ }^{42}$, que na vida real também não se enquadram nestas caixas pré-estabelecidas (VAN HEAR, BRUBAKER, BESSA, 2009; VAN DER KLAAUW, 2009 ). Nesse sentido, as migrações também excedem essas classificações que buscam diferenciar o direito de migrar.

A incapacidade deste modelo restritivo de política migratória de atingir seus autoproclamados objetivos está amplamente documentada. Diversos autores (CORNELIUS et al., 2004; CASTLES, 2004; LAHAV, GUIRAUDON, 2006) investigaram e continuam a investigar as razões do chamado gap (no sentido de falha ou distância) entre os objetivos e os resultados obtidos. Apesar da restritividade mostrar-se ineficaz, não parece haver tendência de abandono desse modelo. A própria consideração da existência de um gap parte de um nacionalismo metodológico que considera apenas a declarada vontade dos Estados em controlar as migrações. Durante muito tempo, esse foi o único ponto de vista relevante, inclusive para os pesquisadores. Sem indagar os migrantes e a sua realidade, a análise da questão da movimentação de pessoas era unilateral, do ponto de vista dos Estados (DE GENOVA, 2002).

O problema que leva a este gap estaria na falta de compreensão de que existem diversas situações migratórias (FREEMAN, 2006). Ou seja, o contexto político da discussão a respeito dos vistos de trabalho seria diferente daquele sobre os vistos de refúgio, e dos vistos de estudo daquele sobre turismo. Observando a partir de uma perspectiva racionalista, a chave

\footnotetext{
${ }^{42}$ Esta hierarquia de legitimação já é em si questionável, por exemplo, no caso das migrações econômicas, em que a ajuda ao desenvolvimento é estimulada como forma de evitar as migrações, mas esta chega apenas à metade do volume enviado em remessas para os países de origem dos migrantes, que em 2004 chegaram a 125 bilhões de dólares (GIULIANO; RUIZ-ARRANZ, 2009).
} 
estaria em entender quais os interesses em jogo e quais os custos presentes, difusos ou concentrados, em cada uma destas situações. Assim, por exemplo, a utilização do sistema de quotas para a reunião familiar ou os vistos de turismo responderiam a um modelo de client politics, uma vez que os benefícios são concentrados e os custos são difusos. Em outras situações migratórias, a política de grupos de interesse, majoritária, etc. seria mais explicativa.

Outros autores, partindo da mesma constatação, ou seja, de que as políticas migratórias adotadas pelos diversos Estados, em geral, não atingem os objetivos declarados, mas verificando que a explicação de Freeman, baseada em noções objetivas e racionais a respeito de custos e interesses envolvidos nos diversos tipos de situação migratória não era suficiente, adicionaram outros elementos à explicação do fenômeno. Em temas sensíveis como imigração ou como segurança, não bastaria apenas analisar as condições objetivas que definiriam interesses e custos. Nestes âmbitos, importa a percepção que as pessoas ou os grupos têm do fenômeno (STATHAM; GEDDES, 2006). Ou seja, elementos subjetivos se somam, já que a realidade só pode ser conhecida a partir de um conjunto específico de valores (SILVA, S., 2005). E como se constroem estas percepções?

Considerando-se a imigração em suas diversas formas como um objeto socialmente construído, a imigração irregular, por exemplo, pode ser lida tanto como uma situação que envolve indivíduos que sofrem com máfias que exploram seu trabalho e violam diversos direitos seus; como indivíduos que se dirigem aos países mais desenvolvidos para se aproveitar, de forma abusiva, dos benefícios do welfare state (BOSWELL et al., 2011); ou ainda, como pessoas que tem o direito de buscar condições de vida digna para si e seus familiares, onde estas estejam disponíveis. Algumas narrativas passam a ideia de que é possível controlar a imigração, gerando expectativas irreais na população e sustentando o paradigma da "ilegalidade". Este é um campo de disputa política. Estas narrativas ou quadros (frames) são

um conjunto de mapas morais e cognitivos que orienta um ator dentro de uma esfera da política (...) ajudam os atores a identificar problemas, especificar e priorizar interesse e objetivos e conduzem os atores para julgamentos sobre as políticas efetivas e apropriadas, impulsionando a política por um determinado caminho (...) (BLEICH, 2002).

$\mathrm{Na}$ construção destes quadros incidem definições, analogias, metáforas e símbolos sobre o tema. A partir destes se conceitua uma situação e se identificam problemas e objetivos (BLEICH, 2002). O nacionalismo metodológico e o paradigma da "ilegalidade" criam o 
problema social das migrações e preparam o terreno para a criminalização das migrações e a securitização das fronteiras.

Os resultados obtidos pelas políticas que limitam as possibilidades de migrar regularmente, estabelecem patrulhas e controles de fronteira cada vez mais reforçados ${ }^{43}$ são mortes, violações de direitos, o incentivo à atividades criminosas que lhes permitem a entrada diante de tantas barreiras - contrariamente aos objetivos declarados - e, finalmente, a criação de um inimigo, o migrante. Ainda há a exploração do trabalho, pois a vida dos indocumentados sob a ameaça de deportação ${ }^{44}$ ou sem acesso a direitos por ausência de documentação é caracterizada por grande vulnerabilidade social e laboral.

Esse aspecto pode ser ilustrado com dois exemplos: um recente relatório a respeito das mortes na fronteira do México com os Estados Unidos demonstra que estas aumentaram significativamente com o aumento da securitização das fronteiras a partir de 1990. O reforço na vigilância da fronteira e a construção de muros levou os imigrantes a buscar a travessia em áreas mais remotas, como o deserto do Arizona. As crescentes mortes ocorrem sobretudo por desidratação, hipertermia ou hipotermia; no setor de Tucson (Arizona), as mortes aumentaram de 8 em 1990, para 225 em 2010 e, apesar do constatado declínio na entrada não-autorizada de imigrantes em razão da crise econômica internacional, em 2012 foram 171 mortes (THE BINATIONAL MIGRATION INSTITUTE, 2013). O Brasil possui $15.719 \mathrm{Km}$ de fronteiras terrestre, com uma estrutura e pessoal de controle muito inferior ao dos Estados Unidos, de modo que é ainda mais clara a impossibilidade de se falar em uma política de fechamento de fronteiras aqui.

Como já se viu, os movimentos migratórios são caracterizados por uma excedência ou autonomia com relação às leis e políticas migratórias. Ressalte-se que esta afirmação, no entanto, não reduz a compreensão a um mero desajuste entre as leis e os padrões de migração atuais (DE GENOVA, 2002). Diante da construção das políticas migratórias de forma unilateral, resta aos imigrantes fazer uso das opções disponíveis, de modo a conseguir realizar o seu projeto migratório, ou simplesmente burlá-las. É necessário, no entanto, não perder de vista que as opções e as condições de migração disponibilizadas servem a objetivos do Estado, muitas vezes não declarados.

\footnotetext{
${ }^{43}$ Ver PÓVOA NETO, 2008.

${ }^{44}$ No Brasil as deportações não são prática comum em razão da previsão constitucional do art. 5, LXI que estabelece que somente haverá prisão por flagrante delito, decisão judicial ou em caso de crime militar ou transgressão militar. Ocorre apenas quando é possível acompanhar o migrante imediatamente até a fronteira. Em todo caso, quando verificada a estadia não autorizada no país, o migrante recebe a ordem de deixar o país em até 8 dias, sob pena de multa e deportação.
} 
Assim, deve-se ir além dos objetivos declarados do Estado e enxergar a existência de objetivos não declarados, como a criação de um problema ou de um inimigo. O objetivo de barrar a imigração é um objetivo impossível diante da "capacidade criativa inquieta e do poder produtivo único das pessoas" (DE GENOVA, 2002). Falar em simples falências da política ou da lei é "empirismo ingênuo" (DE GENOVA, 2002). A existência de objetivos não-declarados fica mais clara quando, passados anos de políticas que não atingem aqueles declarados, os Estados continuam a insistir nas mesmas políticas.

A análise da irregularidade migratória passa, então, pela análise dos processos sociopolíticos de "ilegalização", ou produção jurídica da ilegalidade, que incluem através da "ilegalização". Os indocumentados não são constituídos para sua exclusão física, mas para sua inclusão social sob condições impostas (DE GENOVA, 2002). A irregularidade é condição que vulnerabiliza o imigrante em diversas situações a depender do alcance dos controles realizados. Na passagem para o Estado moderno, criou-se a figura da existência legal, através da sua relação abstrata com a lei, em adição à existência física (DE GENOVA, 2002), mas os imigrantes irregulares hoje só tem direito a esta última.

No seu quotidiano, sobretudo em países como o Brasil, onde os controles são restritos à autoridades migratórias pouco estruturadas, a irregularidade pode parecer menos relevante, eis que, os migrantes nessa condição estabelecem relações sociais diversas também com migrantes regulares ou com nacionais do país de residência. Mas estas relações são atravessadas por espaços de não existência, como por exemplo: possibilidade apenas parcial de documentar a sua realidade; temporalização de sua presença (determinante para qualificálos a permanecer no território nos casos de Anistias, por exemplo); a delimitação do parentesco (determinante para fins de reunião familiar); a transformação de atividades quotidianas e simples em ilícitas (trabalhar, dirigir, viajar); a restrição da mobilidade física e social (como as limitações à mudança de emprego e de local de residência do Estatuto do Estrangeiro ${ }^{45}$ ); além da revogação da promessa de futuro, (impossibilidade de fazer planos de longo prazo), que decorre da precariedade de suas posições jurídicas (DE GENOVA, 2002). A vida dos imigrantes irregulares hoje revela a insuficiência dos parâmetros da existência legal dos indivíduos criada no Estado moderno.

As políticas migratórias centradas na irregularidade, no entanto, além de servir para a construção da migração como um problema, servem ao estabelecimento de diferenciações racializadas e espaciais que reduzem os migrantes à disponibilidade de sua mão de obra por

\footnotetext{
${ }^{45}$ Sobre o Estatuto do Estrangeiro, ver p. 86.
} 
um baixo preço (DE GENOVA, 2002). As barreiras que produzem a "ilegalidade" não precisam ser muros e patrulhas nas fronteiras; podem ser, por exemplo, a culpabilização dos trabalhadores vítimas de exploração, como ocorre com os bolivianos no Brasil; ou a própria incapacidade da burocracia estatal em processar a documentação dos imigrantes, gerando emergências humanitárias, como é o caso dos haitianos no Brasil.

No caso dos imigrantes bolivianos e latinoamericanos no Brasil, eles foram considerados um grave problema, em especial em razão das condições de trabalho a que se submetiam. Com o advento do Acordo sobre Residência para os nacionais dos Estados Partes do Mercosul, Bolívia e Chile em $2009^{46}$ este quadro começou a mudar. Ainda existe exploração do seu trabalho, ainda existem muitos em situação irregular, apesar das possibilidades de regularização ${ }^{47}$. No entanto, já são valorizados de forma diferente na sociedade. São tratados como trabalhadores, enquanto passam a ser considerados problema, os africanos para os quais a única possibilidade de obtenção de documentos é o refúgio ou as constantes anistias ${ }^{48}$.

No caso dos haitianos, a insuficiência do serviço de emissão de vistos em Porto Príncipe, somada à demora na construção de uma política de acolhimento para estes migrantes que o Brasil expressamente se dispôs a acolher, abrem brechas para aqueles que querem ver aí um problema social. Ainda que o volume da imigração seja relativamente pequeno o objetivo de estigmatização (DE GENOVA, 2002) é atingido.

É interessante notar que, da mesma forma, as anistias não contrariam o postulado da centralidade da irregularidade migratória, ao contrário, a confirmam. Elas dão existência jurídica àqueles que até então só possuíam existência física no território, enquanto referendam que outros passem a ocupar o lugar da irregularidade, não eliminando o campo da ilegalidade (DE GENOVA, 2002), e apresentando-se como um favor do Estado.

Como se vê, a ideia de fronteiras fechadas ou fortalezas não serve para explicar grande parte das políticas migratórias atuais, pois para alguns as fronteiras são abertas e há incentivos (mas uma série de condições devem ser atendidas e respeitadas), para outros não, e nessas

\footnotetext{
${ }^{46}$ Atualmente fazem parte do acordo também: Peru, Colômbia e Equador.

${ }^{47}$ Desconhece-se a existência de estudos empíricos que investiguem as razões desta situação.

${ }^{48}$ Ver, por exemplo, a nota da Coluna Holofote da Revista VEJA que faz referência a uma pesquisa a qual aponta que "80\% dos haitianos desejam deixar o país. E a maioria tem o Brasil como destino preferido". Afirma, no entanto que "não são só os haitianos que preocupam o Ministro de Relações Exteriores, Luiz Alberto Figueiredo". O problema seriam os africanos e asiáticos, sobretudo bengalis, senegaleses e nigerianos que "pedem refúgio e somem" (sic). Diz a Polícia Federal que "eles têm treinamento miliciano e passam a atuar no crime organizado" (CABRAL, 2014). Ressalte-se que, não obstante, as pertinentes críticas à qualidade editorial desta publicação ela ainda tem um número de leitores significativo. Nesse caso, específico, retrata bem a essencializante postura da Polícia Federal e do Itamaraty sobre a migração africana.
} 
diferenciações reproduzem-se hierarquias raciais e coloniais (RIGO, 2011). O objetivo da criação de diversas categorias de imigrantes é o mesmo: separar entre desejáveis e indesejáveis, e impor condições que os classifiquem como um ou outro.

A superação do nacionalismo metodológico das políticas migratórias e da cidadania é uma mudança profunda, e deve considerar que a migração submetida a controle é funcional ao sistema capitalista. Os institutos jurídicos e as políticas dos Estados são articulados para diminuir custos e ampliar lucros (HEWINSON; KALLERBERG, 2012). A precariedade ${ }^{49}$, não é, assim, uma condição exclusiva dos migrantes irregulares, os migrantes regulares e até mesmo os cidadãos vivem neste mesmo espaço de domínio e exploração e estão submetidos à mesma estratificação que vai da cidadania à irregularidade (MEZZADRA, 2011), e se operacionaliza através de hierarquias raciais e coloniais ${ }^{50}$.

O imigrante indocumentado é mão de obra barata que serve a setores ávidos de redução de custos. Já os migrantes regulares se submetem a uma série de condições relativas ao nível ou ao setor de sua qualificação, restrições a deixar o emprego para o qual foram contratados e a obrigação de ter que deixar o país após a cessação do contrato. Trata-se de uma força de trabalho com poucos ou nenhum direito e, portanto, mobilizável em tempos de crescimento e descartável nos de crise da economia. Nesse sentido, as migrações são produzidas e não auto-geradas; obedecem a um padrão, não são aleatórias (DE GENOVA, 2002; SASSEN, 1998), o que não exclui a sua excedência.

As políticas migratórias construídas em torno da irregularidade e o processo de criminalização e securitização que elas promovem legitimam os Estados a proteger sua prerrogativa soberana de realizar este descarte. Toda a ordem jurídica nacional opera (políticas migratórias e de cidadania) para que, estando presente o imigrante, ele seja explorado e não servindo mais, ele possa ser descartado. É o que se chama deportability, a condição de sempre poder ser deportado (SQUIRE, 2011). Os Estados, mesmo os mais ricos, não têm condições de realizar esta operação de forma total, mas a existência da possibilidade já serve ao seu propósito.

Assim, as políticas migratórias atualmente em vigor não tratam as migrações como resultantes dos processos sociais, crescentemente transnacionais (e também parte ativa dessa transformação social) com a imprevisibilidade e a turbulência que as distinguem no tempo da

\footnotetext{
${ }^{49} \mathrm{O}$ trabalho precário é frequentemente associado ao que é feito por um contrato não regulado, por tempo determinado, autônomo, casual, temporário, por chamada, realizado em casa, com seus próprios recursos, fornecido por agências de recrutamento. Geralmente tem baixos salários, poucos ou nenhum benefício, com limitada ou sem representação coletiva, e pouca segurança (HEWINSON; KALLERBERG, 2012).

${ }^{50}$ Ver ponto 2.1 .
} 
globalização (MEZZADRA, 2006), e a consequente incapacidade do Estado em controlá-las. Ao contrário, as políticas restritivas fracassadas consolidam o tratamento das migrações como um problema, para o qual alguma solução deve ser encontrada (CASTLES, 2010 e MEZZADRA, 2006).

Além do controle de fronteiras, ganha destaque nos novos esquemas migratórios a reiteração constante das fronteiras no tempo, com a imposição de prazos e condições para renovação da estadia. Os inúmeros controles que se fazem já dentro do território, renovação de vistos, de residência, comprovações de contrato de trabalho, de renda, de antecedentes criminais, etc. agravam a situação de vulnerabilidade. Esta expansão das fronteiras no tempo coloca o migrante sempre sob o risco de se ver em condição irregular, mesmo depois de anos de vida e trabalho com status regular (RIGO, 2011). São faces desta transformação das fronteiras em um instrumento de diferenciação (segundo critérios de raça, gênero, classe) dentro do mesmo espaço político-jurídico, em contraposição à sua tradicional função de separação física entre indivíduos (RIGO, 2011).

Ao se analisar as migrações a partir da perspectiva dos imigrantes, consegue-se perceber a grande ambivalência do processo migratório e a funcionalidade da lógica diferenciadora da cidadania. As práticas de resistência dos imigrantes ocorrem em uma complexa economia de exploração e securitização, fundadas na diferenciação da cidadania nacional de forma articulada com as diferenciações raciais e coloniais. Entendendo as migrações como uma demanda de liberdade, faz bastante sentido o princípio declarado pelo Fórum Social Mundial das Migrações em defesa do direito a migrar, mas também do direito à não migrar (WSFM, 2012; WSFM, 2010).

Diante das estratégias dos próprios migrantes para realizar seus projetos e da imprevisibilidade e a turbulência dos movimentos migratórios contemporâneos que daí resultam, mobilizam-se novas estratégias de securitização e controle. A externalização das fronteiras (HYNDMAN; MOUNTZ, 2008), caso emblemático da Europa, realiza-se não somente por meio de patrulhas em alto-mar mas também e sobretudo através de acordos com países de origem ou trânsito para repassar a eles a tarefa de reter os imigrantes antes que solicitem refúgio na Europa. Apesar dos discursos que mobilizam a retórica dos direitos humanos como base de tais políticas, estas se chocam com a filosofia humanista e ordenamento jurídico europeu garantista.

Uma reconciliação com os seus princípios exigiria que a imigração fosse tratada, discutida, refletida e retratada em termos de proteção dos direitos dos imigrantes. A ideia de objeto socialmente construído, ou de narrativas políticas sobre o mesmo, não se confunde 
com o construtivismo enquanto teoria estrita. O objetivo deste trabalho não é simplesmente descrever como a ideia a respeito da imigração em suas várias formas é construída, mas partindo desta premissa e da verificação de como tal objeto está ou não está construído (PIRES, 2008), aferir seus efeitos e também cotejá-la com os princípios e valores que informam os ordenamentos jurídicos.

1.3 O tratamento internacional das migrações: tecnocracia a serviço do status quo

O artigo XIII, 2 da Declaração Universal dos Direitos Humanos da ONU estabelece o direito do ser humano a emigrar e a retornar ao próprio país. É um direito parcial, pois não prevê o direito a entrar em outro país ou a obrigação de outros países de recebê-lo. Apesar disso, existem outras normas internacionais, específicas ou não, que são aplicáveis aos migrantes, ainda que pouco invocadas. Finalmente, em especial nas duas últimas décadas, uma série de diálogos e discursos internacionais sobre o tema foram se desenvolvendo em diversos níveis e esferas e também contribuem para a governança do tema, que, no entanto, é fragmentada e fraca diante da predominância de uma postura soberanista por grande parte da comunidade internacional.

A Organização Internacional do Trabalho $(\mathrm{OIT})^{51}$ foi historicamente encarregada da proteção dos direitos dos trabalhadores migrantes, tendo adotado algumas Convenções sobre o tema. Na década de 1970, a ONU tornou-se fórum de discussões a respeito. Em 1990, adotou a Convenção da ONU sobre Trabalhadores Migrantes. No processo de negociação deste instrumento, a questão mais controversa foi a imigração irregular, evocando a difícil compatibilização entre a proteção dos direitos humanos dos imigrantes e a criminalização das migrações. Embora não coloque em questão a prerrogativa dos Estados de determinar quais estrangeiros serão ou não admitidos em seu território, tal Convenção foi o primeiro e ainda é o único instrumento internacional amplo que busca garantir direitos humanos (além dos trabalhistas) para os imigrantes. Parte deste conjunto de direitos é garantida também para os migrantes irregulares.

Normativas específicas sobre o tema do Refúgio, a já citada Convenção da ONU

\footnotetext{
${ }^{51}$ Constituída em 28 de junho 1919, por meio dos artigos 387 a 399 do Tratado de Versalhes (Parte XIII), a OIT instalou-se em Genebra a partir de 1926. Em 1944, por meio da Declaração da Filadélfia, foi remodelada e passou a fazer parte do sistema da ONU.
} 
sobre o Estatuto dos Refugiados de 1951 e os Protocolos sobre o Tráfico de Pessoas e o Contrabando de Imigrantes ${ }^{52}$ encontram-se bastante consolidadas. A proteção dos refugiados conta ainda com uma Agência específica junto à ONU, o ACNUR. A Organização Internacional para as Migrações (OIM), por sua vez, não faz parte do sistema onusiano e funciona mais como uma prestadora de serviços para os diferentes países como se verá adiante (BETTS, 2011; GIORGI, 2010). Finalmente, durante os anos 2000, formar fóruns, diálogos, comissões, grupos foram as vias adotadas para tratar do tema das migrações.

Uma breve cronologia inclui: em 2003 a formação da Comissão Mundial sobre as Migrações Internacionais (GCIM) ${ }^{53}$ composta por especialistas; em 2006, a criação do Grupo sobre Migrações Globais $(G M G)^{54}$ para concertação entre as várias organizações internacionais que possuem interface com o tema; no mesmo ano, o Alto Diálogo sobre Migração e Desenvolvimento ${ }^{55}$ aprovado pela Assembleia Geral da ONU (AG); e a partir de 2007 a realização do Fórum Global sobre Migração e Desenvolvimento (GFMD) ${ }^{56}$, fora do quadro da ONU. Em âmbito regional, a Conferência Sul-americana sobre Migrações (CSM) reúne representantes governamentais responsáveis pelo tema e já está em sua $12^{\mathrm{a}}$ edição ${ }^{57}$.

Voltando à normativa internacional geral relativa aos direitos dos migrantes, a OIT possui duas Convenções específicas sobre Migração. A primeira delas é a Convenção n. 97 de 1949 sobre os Trabalhadores Migrantes, ratificada pelo Brasil e incorporada pelo Decreto 58.819 de 1966. Esta Convenção traz garantias trabalhistas (artigo $6^{\circ}$ ) e de apoio ao trabalhador migrante em sua chegada ao país ${ }^{58}$. O documento refere-se a um período em que a dinâmica das migrações era muito mais determinada pelos Estados, com programas de atração

\footnotetext{
${ }^{52}$ Protocolos adicionais à Convenção das Nações Unidas contra o Crime Organizado Transnacional de 2000. O Protocolo contra o Tráfico de Pessoas intitula-se: Protocolo Relativo à Prevenção, Repressão e Punição do Tráfico de Pessoas, em Especial Mulheres e Crianças e o Protocolo contra o Contrabando de Imigrantes intitulase: Protocolo Relativo ao Combate ao Tráfico de Migrantes por Via Terrestre, Marítima e Aérea. A denominação em português pode gerar confusão pelo uso em ambas da expressão "tráfico". Em inglês, no primeiro caso falase de trafficking in persons e no segundo smuggling. O primeiro envolve engano ou coerção e exploração, já no segundo, promove-se a entrada do migrante sem autorização no território mediante remuneração. Em espanhol também diferencia-se a trata do trafico de pessoas, sendo que nesse caso, a trata é o mais grave equivalente ao trafficking in persons. De forma resumida, o tráfico constitui crime contra a pessoa, e o contrabando, contra os Estados (PEIXOTO, 2007).

${ }^{53}$ Global Commission on International Migration, em inglês.

${ }^{54}$ Global Migration Group, em inglês.

${ }^{55}$ UN High Dialogue on Migration and Development, em inglês.

${ }^{56}$ Global Forum on Migration and Development, em inglês.

${ }^{57}$ Em 1994, na Conferência do Cairo sobre População e Desnvolvimento, reconheceu o tema das migrações como um tema inserido nas discussões políticas, econômicas e culturais. Ver: PÓVOA NETO; SPRANDEL, 2009.

${ }_{58}$ Por exemplo, em virtude do artigo $2^{\circ}$ "Todo Membro para o qual se ache em vigor a presente Convenção obriga-se a manter um serviço gratuito adequado incumbido de prestar auxílio aos trabalhadores migrantes e, especialmente, de proporcionar-lhes informações exatas ou assegurar que funcione um serviço dessa natureza".
} 
de mão de obra, mas muitas destas previsões, relativas a direitos, continuam plenamente aplicáveis.

Em 1975, foi aprovada outra Convenção da OIT específica sobre o tema, a n. 143, relativa às "Migrações em condições abusivas e à promoção da igualdade de oportunidades e de tratamento dos trabalhadores migrantes", ainda não ratificada pelo Brasil ${ }^{59}$. Seu artigo $9^{\circ}$ previu $^{60}$, pela primeira vez, garantias mínimas trabalhistas para os trabalhadores migrantes em situação irregular, tais como o direito à remuneração pelo trabalho efetivado (HASENAU, 1991). Outros instrumentos não específicos da OIT também são aplicáveis aos migrantes. Em 2006, a Organização publicou um documento não vinculante, resultado de um encontro tripartite de especialistas, contendo princípios e diretrizes para uma abordagem de direitos do trabalho migrante ${ }^{61}$ e elencando todas estas previsões. Os princípios e diretrizes construídos baseiam-se em instrumentos internacionais e em uma revisão das políticas de migração laboral de seus membros. Sendo assim, reproduz o nacionalismo metodológico de todos estes e, na tentativa de promover os direitos dos trabalhadores migrantes, resulta ambíguo. Reafirma o direito soberano dos Estados em definir as suas políticas (item IV, 4), recomenda a expansão de canais de migração regular (item IV, 5) e a proteção dos direitos humanos independentemente da situação migratória (item $\mathrm{V}, 8$ ), ao mesmo tempo em que estimula a luta contra a imigração regular, por meio da legislação e punições (itens VI, 11, 11.1, 11.2, 11.4).

Em 1975, a adoção da Convenção no 143 da OIT expôs sérias divergências entre os Estados. Dentre os países desenvolvidos, o artigo 14, "a"62, era rejeitado, pois teria potencial de prejudicar seus programas de trabalho temporário (Guest-work programs). Para os países

59 O status de todas as Convenções ratificadas e não ratificadas pelo Brasil está disponível em: http://www.ilo.org. Acesso em: 14 mai 2014.

${ }^{60}$ Artigo $9^{\circ}$ : Sem prejuízo das medidas destinadas a controlar os movimentos migratórios com fins de emprego garantindo que os trabalhadores migrantes entram no território nacional e aí são empregados em conformidade com a legislação aplicável, o trabalhador migrante, nos casos em que a legislação não tenha sido respeitada e nos quais a sua situação não possa ser regularizada, deverá beneficiar pessoalmente, assim como a sua família, de tratamento igual no que diz respeito aos direitos decorrentes de empregos anteriores em relação à remuneração, à segurança social e a outras vantagens. Em caso de contestação dos direitos previstos no parágrafo anterior, o trabalhador deverá ter a possibilidade de fazer valer os seus direitos perante um organismo competente, quer pessoalmente, quer através dos seus representantes. Em caso de expulsão do trabalhador ou da sua família, estes não deverão custeá-la. Nenhuma disposição da presente Convenção impedirá os Estados Membros de conceder às pessoas que residem ou trabalham ilegalmente no país o direito de nele permanecerem e serem legalmente empregadas.

${ }^{61}$ A lista de Convenções e outros documentos sobre o tema das migrações pode ser conferida em: ILO, 2006.

${ }^{62}$ Artigo 14. Todo o Estado Membro: a) Poderá subordinar a livre escolha de emprego, assegurando, no entanto, o direito à mobilidade geográfica, à condição de que o trabalhador migrante tenha residido legalmente no país, com fins de emprego, durante um período prescrito que não deverá ultrapassar dois anos ou, caso a legislação exija um contrato de duração determinada inferior a dois anos, que o primeiro contrato de trabalho tenha caducado; 
em desenvolvimento, em especial, os que possuíam grande contingente de emigrantes, o foco de atenção estava nas disposições que estabeleciam a luta contra a imigração irregular. Essa preocupação foi o estímulo que levou Marrocos e México a buscar a adoção de um instrumento amplo de proteção aos direitos dos imigrantes pela ONU onde o equilíbrio de forças era mais favorável a eles (BOHNING, 1991). De fato, a Convenção 143 garante diversos direitos aos migrantes regulares, mas já introduz o discurso do combate à imigração ilegal $^{63}$ e ao longo de todo o texto reafirma a lógica nacionalista.

A situação do grande número de nacionais destes países trabalhando no exterior certamente era uma preocupação central. No entanto, segundo a literatura, eles estariam preocupados também com os seus interesses econômicos com relação à imigração internacional, notadamente, o seu papel de válvula de escape para o desemprego, e a importância das remessas dos imigrantes para a sua economia.

Há que se pontuar, no entanto, que além destes "ganhos", os Estados de emigração têm muitas "perdas" de mão de obra qualificada e de força de trabalho em geral. Por outro lado, relativamente aos interesses econômicos envolvidos na questão, se estes se materializam em defesa de direitos humanos, tanto melhor. Há que se atentar somente para casos em que a emigração não é autônoma, mas estimulada pelo Estado, como ocorre notoriamente nas Filipinas (TYNER, 1999; BRUSH, SOCHALSKY, 2007). Por outro lado, os países receptores não querem perder a sua ampla liberdade de promover programas de trabalho temporário quando precisam de mão de obra para suas economias crescerem, mas consideram legítimo descartar estes trabalhadores quando uma crise se instala. Do ponto de vista dos imigrantes, isto significa violações de direitos em nome dos interesses econômicos dos Estados.

$\mathrm{Na}$ busca por trazer a discussão sobre os direitos dos trabalhadores migrantes para o âmbito da ONU, o Conselho Econômico e Social da ONU aprovou, em 28 de julho de 1972, uma Resolução sobre a Exploração do trabalho através do Tráfico Ilícito e Clandestino que, entre outras coisas, toma nota dos passos realizados pela OIT sobre o tema e a convida para que continue se debruçando sobre o tema, ao mesmo tempo em que instrui a Comissão de Direitos Humanos a examinar a questão em sua própria sessão, recomendando diretrizes para a ação do Conselho. Meses depois, em 15 de novembro, a AG adotou resolução com o mesmo

\footnotetext{
${ }^{63}$ Por exemplo, em virtude de seu artigo 3. ${ }^{\text {: }}$ "Todo o Estado Membro deverá tomar as medidas necessárias e apropriadas, quer da sua própria competência, quer as que exijam a colaboração de outros Estados Membros: a) A fim de suprimir as migrações clandestinas e o emprego ilegal de migrantes; b) Contra os organizadores de movimentos ilícitos ou clandestinos de migrantes com fins de emprego, provenientes do seu território ou que a ele se destinam, assim como os que se efetuam em trânsito por esse mesmo território, bem como contra aqueles que empregam trabalhadores que tenham imigrado em condições ilegais; a fim de prevenir e eliminar os abusos citados no artigo 2 . da presente Convenção".
} 
título (A/RES/2920) e teor semelhante, recomendando a ratificação da Convenção n. 97 de 1949 da OIT. Outras resoluções sobre o tema foram adotadas nos anos seguintes, sempre seguindo esta mesma linha ${ }^{64}$. Sob sua recomendação, o Conselho Econômico e Social (ECOSOC), a Comissão de Direitos Humanos, a AG e o Secretário-Geral realizaram várias consultas entre si e produziram relatórios a respeito da possibilidade de construir uma Convenção sobre os direitos dos trabalhadores migrantes.

Finalmente, em 17 de dezembro de 1979, com o apoio principalmente dos países do chamado Terceiro Mundo, a AG aprovou a Resolução 34/172, criando o Grupo de Trabalho que iria elaborar o texto da Convenção. Este trabalho consumiu 10 anos, e foi marcado pela contraposição entre as posturas mais garantistas de direitos humanos, capitaneadas pelos países em desenvolvimento, e a posição mais preocupada com a prerrogativa estatal do controle de fronteiras e pessoas admitidas no território de alguns países europeus ocidentais. Em uma posição intermediária, acabou ganhando importância a atuação do grupo chamado MESCA, composto por Estados mediterrâneos e escandinavos à época com governos socialistas florescentes $^{65}$ cuja proposta de compromisso entre os dois grupos acabou moldando a estrutura do texto aprovado (BOHNING, 1991).

A Convenção foi aprovada pela AG em 18 de dezembro de 1990 e entrou em vigor mais de uma década depois em 01 de julho de 2003. Em maio de 2014 eram 47 os Estados Partes da Convenção ${ }^{66}$, a quase totalidade deles do Sul global. As posições divergentes sobre o tema específico dos direitos dos imigrantes indocumentados durante a década de negociação da Convenção, entre 1979 e 1989, determinaram a sua estrutura e o seu conteúdo, notadamente a classificação dos imigrantes em grupos aos quais são garantidos diferentes conjuntos de direitos, mas, sobretudo, a convivência em seu texto de duas ideias aparentemente incompatíveis: a dos direitos humanos dos imigrantes e a da prerrogativa estatal de determinar quem pode ser incluído e quem deverá ser excluído da comunidade nacional (BOSNIAK, 1991). Com efeito, se a migração realmente fosse considerada como um direito humano, não se trataria de uma questão a negociar entre os Estados, eis que receber

\footnotetext{
${ }^{64}$ Resoluções 3224 de 6 de novembro de 1974, 3449 de 9 de dezembro de 1975 e 127 de 16 de dezembro de 1976.

${ }^{65}$ Portugal, Espanha, Itália, Grécia, Suécia, Finlândia e Noruega.

${ }^{66}$ Albania; Algeria; Argentina; Azerbaijão; Banglades; Belize; Bolívia; Bósnia Herzegovina; Burkina Faso; Cabo Verde; Chile; Colômbia ; Equador; Egito; El Salvador; Gana; Guatemala; Guiné; Guiana; Honduras; Indonésia; Jamaica; Quirguistão; Lesoto; Líbia; Mali; Mauritânia; México; Marrocos; Moçambique; Nicarágua; Niger; Nigéria; Paraguai; Peru; Filipinas; Ruanda; Senegal; Seicheles; Sri Lanka; São Vicente e Granadina; Síria; Tadjiquistão; Timor Leste; Turquia; Uganda; Uruguai. Ver: https://treaties.un.org/ Acesso em: 14 mai 2014.
} 
migrantes internacionais configuraria uma obrigação de todo e qualquer país que respeite os direitos humanos (DUMMETT, 2004).

Em que pese a estratégia para a aprovação escolhida pelo Grupo de Trabalho que a redigiu, qual seja a do compromisso entre direitos humanos e soberania, a questão dos direitos humanos dos imigrantes irregulares efetivamente estava em pauta. A Convenção levou treze anos para entrar em vigor $^{67}$. O seu período de negociação coincidiu com diversas transformações no cenário internacional. A tão citada crise do petróleo de 1973 e as transformações na economia que se seguiram com o advento do capitalismo neoliberal deixaram a sua marca também neste processo. Em 1990 quando finalmente foi aprovada, o tema das migrações se havia inserido nas agendas políticas mais sensíveis dos países do Norte. Poucos anos depois a securitização tomaria conta do tema, e as migrações internacionais finalmente receberiam grande atenção da comunidade internacional.

A inclusão dos imigrantes indocumentados em ao menos algumas das previsões era aceita, desde o início, pela maior parte do grupo, diferentemente do que ocorreu durante os debates para a redação da Declaração das Nações Unidas sobre os Direitos Humanos dos Indivíduos que não são Nacionais do País onde Vivem (A/RES/40/144, adotada pela Assembléia Geral em 13 de dezembro de 1985), quando a questão gerou celeuma. Essa Declaração, por exemplo, não menciona explicitamente os imigrantes indocumentados, mas divide as garantias para "os estrangeiros" (art. 5 e 6) e para "os estrangeiros legalmente residentes" (art. 7 e 8) (BOSNIAK, 1991).

No que se refere à Convenção, o debate centrou-se mais na extensão dos direitos garantidos aos indocumentados, sem aprofundar demasiado as questões mais árduas e profundas implicadas na garantia de direitos a este grupo, de modo a facilitar uma solução de compromisso (BOSNIAK, 1991). A tensão entre as garantias de direitos dos migrantes e as prerrogativas soberanas dos Estados não foram enfrentadas na tentativa de construir um texto que pudesse ser aceito por todos.

Apesar disso, são nítidas duas posições. Os defensores de maiores garantias de direitos para os imigrantes indocumentados centravam o seu argumento na ideia de que a vulnerabilidade generalizada a que estavam expostos, frente ao Estados, aos empregadores, aos proprietários de imóveis e à sociedade em geral, estimulava a exploração. Mais que isso, além de favorecer abusos na experiência migratória destes trabalhadores, essa vulnerabilidade

\footnotetext{
${ }^{67}$ De acordo com o artigo 87 da Convenção: 1. A presente Convenção entrará em vigor no primeiro dia do mês seguinte a um período de três meses após a data do depósito do vigésimo instrumento de ratificação ou de adesão.
} 
também impactava na sociedade em geral, dentro da qual se produzem e se mantêm estas relações com violações de direitos. Assim, além da ideia da universalidade dos direitos humanos, buscavam mostrar que o reconhecimento desse princípio era a melhor política a ser adotada (BOSNIAK, 1991).

Por outro lado, os opositores da ampliação do reconhecimento de direitos sustentaram a tese de que mais direitos atrairiam ainda mais migrantes. A solução deveria ser a oposta, tornar mais difícil a vida do imigrante, com mais controles e securitização, impedindo-os de entrar e mandando uma mensagem de desestímulo aos que pensassem em empreender essa jornada (BOSNIAK, 1991). Não obstante, a Convenção garante uma série de direitos, inclusive para os irregulares e nem poderia ser diferente em uma Convenção redigida sob o mandato da ONU.

A Convenção é, assim, ambivalente. Essa ambivalência se revela menos na distinção entre os migrantes autorizados (Parte IV) e os irregulares (Parte III), e mais na reafirmação expressa de que os Estados têm total liberdade para definir os critérios de admissão dos migrantes (art. 79) e nada na Convenção implicará a regularização ou um direito à regularização para os que não possuem documentos (art. 35). O mais próximo a um critério de limitação deste poder estatal pela Convenção é a norma programática do art. 64, em virtude da qual a gestão da migração internacional deve levar em conta não somente as necessidades de mão de obra, mas também as necessidades sociais, econômicas e culturais dos trabalhadores migrantes (grifo da autora). É positivo notar, ainda, a importância que a Convenção dá ao tempo de permanência do imigrante no Estado de emprego. Ou seja, defende a ideia que com o passar dos anos é necessário que a precariedade da residência diminua (arts. 49-52).

Alguns direitos que são reconhecidos apenas para os migrantes regulares são impossibilitados aos migrantes irregulares, mas há outros que perdem a sua razão de ser pela própria condição de irregularidade daí a importância da promoção da regularização, o que não existe na Convenção. Ao contrário, são previstas apenas medidas repressivas para fazer cessar a imigração irregular (art. 68). São assim os direitos políticos e o direito ao voto (art. 41) e à reunião familiar (art. 34), que não podem ser solicitados por aquelas pessoas que não "existem" para o Estado. Além disso, o direito à livre circulação pelo território e eleição do local de residência (art. 39) ou de buscar um emprego alternativo (arts. 49 a 52), que só têm razão de ser quando o Estado admite e regulamenta a presença do migrante. A grande diferença de garantias está na extensão dos direitos sociais e da igualdade de tratamento em relação aos nacionais. No caso dos migrantes irregulares, a igualdade de tratamento refere-se somente a alguns direitos trabalhistas (art. 25). Além disso, a maior parte dos direitos que lhe 
são garantidos são civis, com a adição de atendimento de urgência em saúde (art. 28) e educação para os seus filhos (art. 30).

Passados vinte e quatro anos da sua adoção, ela foi ignorada enquanto outros paradigmas normativos ganharam força, notadamente o do combate a imigração irregular ao qual, mais recentemente, se acrescentou o da gestão das migrações. Com todas as suas limitações e ambigüidades, apostava-se que esta Convenção pudesse mudar o critério internacional de legitimidade associado ao tratamento dos migrantes indocumentados (BOSNIAK, 1991). Isso não ocorreu, mas para avançar rumo a uma solução efetiva para o drama dos imigrantes que arriscam suas vidas atravessando fronteiras é necessário que se resgate o paradigma de direitos a partir do qual se debatia o tema das migrações à época, rechaçando o paradigma securitário e tecnocrático hoje vigente.

$\mathrm{Na}$ América do Sul, no entanto, aparecem alguns focos de resistência. Em 2005, a Argentina aprovou uma nova legislação migratória construída a partir dos direitos humanos e ratificou a Convenção da ONU sobre Trabalhadores Migrantes em 2007. O Brasil manifesta intenção de seguir pelo mesmo caminho: durante os anos do governo Lula, a política externa brasileira foi ativa na denúncia das contradições das políticas migratórias dos países do Norte em relação aos direitos humanos dos migrantes (REIS, 2004). Apesar disso, a Convenção da ONU continua à espera da análise do Congresso Nacional desde $2010^{68}$ e a adoção de uma legislação migratória baseada nos direitos humanos caminha muito lentamente ${ }^{69}$.

A adoção de uma paradigma de direitos requer o questionamento justamente das leis que colocam os imigrantes na condição sócio-política de inimigo e na condição jurídica de ilegalidade. Tendo em vista o debate ocorrido durante a construção do texto da Convenção de 1990, percebe-se que argumentar a favor dos direitos dos migrantes parece ser pouco efetivo quando questões mais profundas ligadas ao Estado, à soberania e à mobilidade entendida como patologia permanecerem sem questionamento (MOULIN, 2011; BIGO, 2002).

Os Estados mantêm sua autoridade legal para impedir a entrada e excluir os imigrantes, objetivo que não conseguem realizar. É certo que a proibição contém em si a sua violação, mas a questão que deve ser colocada é: “por que é proibido?" É legítimo proibir determinada conduta? Visto que os Estados já não conseguem controlar as suas fronteiras mesmo que impeçam a entrada de alguns, outros virão - estas medidas só tem um efeito:

\footnotetext{
68 Encaminhada à Câmara dos Deputados através da MSC 696/2010, o texto está desde junho de 2011 aguardando a constituição de comissão especial para analisá-la, em que o tema foi considerado ser de competência de mais de três Comissões. Ver: http://www.camara.gov.br. Acesso em: 15 mai 2014.

${ }^{69}$ Ver ponto 2.2 .
} 
caracterizar a sua situação jurídica como ilegal e, assim, transformá-lo mais facilmente em inimigo (BIGO, 2002).

Durante muito tempo a imigração não-autorizada era tolerada e não era vista como uma ameaça à soberania. Na França, no início dos anos 70, a imigração irregular constituía quase $80 \%$ do total e era designada como migração espontânea (BOSNIAK, 1991). Da mesma forma, no início dos anos 70, os EUA não tinham interesse em cessar o fluxo de trabalhadores estrangeiros para trabalhar na sua agricultura (BOHNING, 1991).

Com as mudanças na economia e na política internacional e internas, e na movimentação das pessoas essa visão se transformou. A partir dos anos 1980 os refugiados e imigrantes, em especial os indocumentados, foram alçados à condição de ameaça à economia e à soberania nacional. É interessante notar como o discurso/lógica da ameaça à soberania nacional e da necessidade de controlar melhor as fronteiras se aproxima daquele relativo à entrada de drogas e armas no território nacional. Inclusive algumas das normativas internacionais mais consolidadas sobre o tema das migrações são justamente as relativas à criminalidade transnacional ${ }^{70}$. Seriam estas ameaças equivalentes? De fato, essa ideia pauta muitas práticas no campo das migrações.

A situação se agrava quando esta aproximação ocorre também na execução da política migratória. No Brasil, a competência de Polícia Migratória é da Polícia Federal (PF). O mesmo órgão é responsável pelo processamento de grande parte da burocracia de registro migratório, além de possuir poder decisório em algumas situações. Foi o caso do processo de Anistia Migratória de 2009, quando a PF não somente recebia a documentação, mas fazia uma análise inicial a respeito da documentação. Mesmo ao aplicar uma normativa que objetivava a regularização de todos os imigrantes, a Polícia Federal, treinada para investigar e prender criminosos, acreditava que era adequado rejeitar a concessão do registro em muitos casos em que a documentação apresentada era frágil (PYL, 2009). A justificativa era a preocupação de não documentar nenhum criminoso - ressalte-se que ter documentos brasileiros não isenta as pessoas de suas responsabilidades criminais -, e, assim, diversos trabalhadores, sobretudo os informais, permaneceram na condição irregular, mesmo havendo em termos normativos a disposição do governo de retirá-los dessa condição.

O controle das fronteiras e a prerrogativa de determinar quem será ou não admitido em seu território, qual seja, a de definir seu povo, está intimamente ligada ao conceito de

\footnotetext{
${ }^{70}$ Ver a Convenção das Nações Unidas contra o Crime Organizado Transnacional e seus Protocolos relativos ao Tráfico de Pessoas e ao Contrabando de Imigrantes.
} 
soberania e à capacidade do Estado de governar o seu povo e o seu território, como já se viu. É lugar-comum dizer que a soberania é um conceito em decadência. No entanto, a defesa da sua integridade é fortemente presente em alguns campos, como a imigração. Cria-se um inimigo e criminaliza-se uma dinâmica subjetiva, apresentada como ameaça ao Estado, mas que em certa medida, economicamente, the serve. O que não quer se perder é o controle da entrada e o da deportabilidade dos imigrantes quando estes deixarem de servir. Assim, tratar o imigrante como ameaça encaixa-se plenamente no esquema do Estado nacional (BIGO, 2002), tratamento que funcionalmente se reproduz entre os órgãos estatais.

Em 2010, a Corte Interamericana de Direitos Humanos julgou um caso sobre a detenção de um imigrante equatoriano indocumentado no Panamá, o Sr. Velez Loor (CIDH, 2010). Ele foi preso em 2002 por entrar sem autorização no território panamenho, onde estava sujeito a um impedimento à entrada. Foi condenado a 2 anos de prisão, sem ter conhecimento do processo ou poder se defender. Permaneceu preso no Panamá durante 10 meses, quando sofreu diversos abusos, violações e torturas, até ser deportado para o Equador após gestões do Consulado deste país. A Corte proferiu sentença sobre o caso em 2010 e, entre outros aspectos, estabeleceu a violação do art. 7.5 (ponto 111) da Convenção Interamericana de Direitos Humanos que estabelece a necessidade de submeter a revisão judicial toda e qualquer situação de detenção, o que não ocorreu no caso de Velez Loor cuja detenção foi estabelecida pelo órgão migratório em desrespeito de uma série de outras garantias do devido processo legal, em especial o direito à defesa. Finalmente, a Corte estabeleceu que a detenção foi arbitrária (ponto 116), que a ausência de fundamentação da mesma indica que o procedimento de detenção de imigrantes irregulares era feito de maneira automática, sem a apreciação das circunstâncias individualizadas (ponto 118).

No que se refere à criminalização da imigração irregular, trazida à discussão pelos representantes do Sr. Velez Loor, apesar de reconhecer a legitimidade dos Estados em controlar e regular o ingresso e a permanência de pessoas estrangeiras no seu território (ponto 97 e 169), a Corte reafirma, de acordo com o estabelecido na Convenção e na sua própria jurisprudência, que o Estado só deve fazer recurso ao poder punitivo para a proteção de bens jurídicos fundamentais contra perigos graves, e que o seu uso contra o reingresso de pessoas deportadas não é legítimo (pontos 169-172). Apesar de ainda bastante sutil, a decisão estabelece um limite concreto às políticas migratórias criminalizantes com base em instrumentos internacionais de direitos humanos, sem, é claro, questionar as prerrogativas soberanas de controle dos Estados, mas apenas os instrumentos utilizados para tanto.

Como se viu, os Estados, que compõe o sistema internacional, na busca da 
manutenção das suas prerrogativas estatais soberanas de controle das migrações, vêm rejeitando a incorporação de compromissos internacionais específicos sobre os direitos dos migrantes, com receio não só de limitar as suas prerrogativas, mas de estimular uma migração indesejada, como se graduar o nível de garantia de direitos pudesse ser instrumento legítimo de gestão migratória. No entanto, a insuficiência dessas estratégias estatais frente à autonomia das migrações, a solução segue o chamado gatopardismo: é necessário mudar tudo para que nada mude (LAMPEDUSA, 1958).

Assim, desde o início dos anos 2000, o tema das migrações passou a ser abordado no nível internacional de outra forma. Nenhum investimento em normas vinculantes, mas a realização de diagnósticos, diálogos, estabelecimento de fóruns e a construção de conceitos como "gestão global das migrações ${ }^{71 ", ~ i m p u l s i o n a d o ~ s o b r e t u d o ~ p e l a ~ O I M ~ e ~ " m i g r a c ̧ a ̃ o ~ e ~}$ desenvolvimento $^{72}$ ", foi levado adiante, sobretudo, pela ONU.

A OIM existe desde 1951. De início era uma agência que se ocupava de questões logísticas, sobretudo de transporte e acomodação de migrantes e refugiados em consequência da $2^{\mathrm{a}}$ Guerra Mundial. Era um Comitê Provisório, inicialmente restrito à Europa. Passou por diversas crises antes de conseguir consolidar-se como Organização permanente em 1989, e em 2014 possui 155 membros. O contexto de fim da guerra fria e de expansão do capitalismo neoliberal imprimiram uma dinâmica nova e intensa às migrações, o que favoreceu esta consolidação (GEORGI, 2010). Além disso, a sua missão foi ampliada para trabalhar com os desafios da gestão das migrações, da compreensão das questões migratórias, da busca do desenvolvimento social e econômicos através das migrações e do respeito à dignidade humana e ao bem-estar dos migrantes ${ }^{73}$.

Estes objetivos são realizados por meio de uma série de serviços que a Organização presta aos Estados. A OIM não faz parte do quadro da ONU e nem possui um mandato de proteção internacional estabelecido, funcionando mais como uma agência privada, financiada sobretudo por projetos, o que é fonte de grande parte das críticas a ela direcionadas. Em 2012, operou um orçamento de 1 bilhão e 240 mil dólares provenientes sobretudo dos mais de 2000 projetos que realizou naquele ano (OIM, 2013). Entre as ações que desempenha, permanece o suporte ao movimento de migrantes, trabalhadores e reassentados; dá treinamento e suporte aos Estados para controle migratório (em muitos Estados africanos este trabalho foi financiado por outros Estados); possui também um papel operativo no controle migratório:

\footnotetext{
${ }^{71}$ Global Migration Management, em inglês.

${ }^{72}$ Migration and development, em inglês.

${ }^{73}$ Ver o site institutucional da Organização: www.iom.int
} 
realiza campanhas de informação sobre a migração regular e contra o tráfico de pessoas, além de gerenciar campos de recepção, detenção ou deportação, executar os muito criticados programas de retorno voluntário ${ }^{74}$ e tomar parte em operações de emergência humanitária (GEORGI, 2010).

Finalmente, a OIM hoje disputa fortemente a hegemonia política sobre o discurso a respeito das migrações internacionais. Com o conceito da gestão global das migrações busca reunir todas estas ações que realiza e fortalecer os seus produtos. De fato a expressão, invocada repetidas vezes por diversas instituições, é bastante ampla e facilita a cooperação entre atores que muitas vezes tem pouco em comum (GEIGER; PÉCOUD, 2010). Em seu material destinado a decisores e operadores das políticas migratórias, a OIM estabelece esta amplitude elencando as principais áreas do programa: migração e desenvolvimento; facilitação das migrações [regulares], incluindo a integração; regulação das migrações [irregulares], incluindo o combate ao tráfico, ao contrabando de imigrantes e o controle de fronteiras e finalmente a área das migrações forçadas (OIM, 2004).

A OIM assim, investe neste paradigma técnico e lucrativo a despeito da garantia dos direitos dos migrantes. No início dos anos 2000, a Organização foi alvo de muitas críticas por parte de movimentos de apoio aos migrantes e mesmo de grandes organizações não governamentais de direitos humanos como a Anistia Internacional (AI; HRW, 2002) e a Human Rights Watch (HRW, 2001). A crítica pesava principalmente sobre os programas de retorno voluntário já mencionados e sobre os campos de detenção e deportação geridos pela OIM no Pacífico. O mote da campanha era: "Against global migration management - For

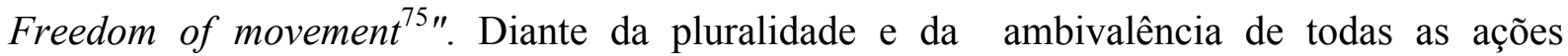
realizadas pela Organização, no entanto, não é possível enxergar uma linha política clara a não ser a busca por projetos que a financiam. O resultado disso não é menos grave, pois o discurso que constrói é o de que a migração é um problema técnico para o qual a OIM oferece as soluções. Assim, despolitiza-se o tema (GEORGI, 2010; GEIGER; PÉCOUD, 2012) e invisibiliza-se a profundidade da luta política que se desenrola entre atores diversos, Estados, cidadãos nacionais e cidadãos migrantes, com interesses diversos e conflitantes.

Durante o mandato de Kofi Annan como Secretário Geral das Nações Unidas houve uma tentativa de reforçar o papel da ONU no tema das migrações. Em 2003, foi lançada a Comissão Mundial sobre as Migrações Internacionais, composta por 19 especialistas. Esta

\footnotetext{
${ }^{74}$ A voluntariedade é questionada, uma vez que a opção alternativa é a deportação ou expulsão forçada.

${ }^{75}$ Campanha promovida pela Rede Noborder. Ver: http://www.noborder.org
} 
Comissão apresentou o seu relatório "As migrações num mundo interligado: novas linhas de acção" em 2005 . O relatório aborda de forma mais ampla a questão dos direitos humanos dos migrantes, mas permanece preso às categorias nacionais, trabalhando os temas da imigração irregular (CMMI, 2005).

Após a realização do Alto diálogo sobre Migração e Desenvolvimento em 2006, que era uma das recomendações da Comissão de Especialistas, os países do Norte conseguiram evitar que o tema das Migrações continuasse a ser abordado dentro da ONU e a continuidade dos trabalhos passou a ser realizada anualmente no Fórum Global sobre Migração e Desenvolvimento (GFMD), um espaço para discussões não vinculantes e fora da $\mathrm{ONU}$ (GEORGI, 2010). O que restou dessa série de eventos foi o patrocínio pela ONU do potencial de desenvolvimento ínsito nas migrações, localizado no envio de remessas e na aquisição de conhecimentos e experiências pelos migrantes que posteriormente retornarão aos seus países com esta bagagem (GCIM, 2005). Este postulado, não é meramente técnico não somente porque traz consigo a ideia da gestão das migrações, mas também porque possui uma forte carga ideológica da filosofia política neoliberal (DE HAAS, 2010), uma vez que referenda o descompromisso estatal e a privatização dos indivíduos. Finalmente, estudos teóricos e empíricos demonstram que a curto e médio prazo, o desenvolvimento não leva à diminuição das migrações, e sim ao seu aumento, diante do aumento da capacidade dos indivíduos em buscar esta alternativa (DE HAAS, 2006).

Como se percebe, há uma mudança no discurso sobre as migrações, agora fortemente promovido pelas organizações internacionais. As migrações, de forma geral, passam a ser tratadas como um processo normal, não mais um problema em si, ao mesmo tempo em que se tenta organizá-las para o maior benefício de todos, por meio, entre outros, da cooperação entre os Estados. A percepção de que a mobilidade de pessoas é parte da dinâmica social, notadamente no tempo da globalização, parece ter se imposto, mas, em verdade, trata-se de uma abordagem tecnocrática que nega ou ignora as implicações políticas dos movimentos migratórios. A mudança com relação ao paradigma da migração-problema é muito mais de discurso, pois o controle e a exploração permanecem. As pessoas são consideradas peças no tabuleiro da economia e da política das migrações, e não como atores do jogo. Logo, a mudança é apenas da estratégia dos atores estatais sobre como melhor manter o controle sobre os seus movimentos. A questão fundamental da exploração e da precarização do trabalho que estão na base do tema não são enfrentadas. Finalmente, a questão do combate à imigração irregular permanece inquestionada, com o peso a mais de que estes migrantes estariam prejudicando os esforços dos países em receber trabalhadores regularmente. 
A crise da cidadania nacional, submetida a uma série de rupturas e contradições, obviamente engendra resistências às transformações desta ordem. Os sistemas jurídicos tentam trazer de volta ao seu interno estas rupturas e contradições, reduzindo-as a normas (RIGO, 2011). É assim que se criam novas estratégias políticas que ao reconhecer, em certa medida, as migrações como um processo normal, tratam de "organizá-las" para o melhor benefício de todos, como são as propostas de global migration management e de políticas de migração circular.

A concretização dessa agenda demonstra ainda que a cooperação, normalmente através de medidas unilaterais, acordos bilaterais ou do co-financiamento de projetos de retorno voluntário, por exemplo, tem sido instrumento de garantia dos interesses dos Estados, mas não necessariamente atendem às demandas dos migrantes, para quem a migração continua sendo um horizonte no caso de sua situação econômica e social não melhorar (CAILLAUT, 2012).

No passado, programas de trabalho temporário já tentaram realizar este objetivo ${ }^{76}$. Hoje, a estratégia de promover a circularidade das migrações são o novo instrumento criado para este fim ${ }^{77}$. Destinam-se a "domesticar as estratégias concretas e as redes transnacionais dos próprios migrantes" (RIGO, 2011), o que soma-se às políticas de atração de trabalhadores qualificados no leque de interesses dos Estados. As políticas de migração circular são apresentadas como um triple win game, onde todas as três partes ganham. Através delas os Estados receptores poderiam obter a mão de obra de que necessitam, qualificada ou nãoqualificada em seus mercados de trabalho. Os Estados de origem da imigração se beneficiariam das remessas e da transferência de conhecimento e investimentos que acompanham os migrantes em seu retorno enquanto os migrantes teriam mais oportunidades de migrar de forma regular e segura. Na prática é muito difícil ver este quadro efetivado pois as restrições de direitos são comuns na implementação destas políticas (AGUNIAS, NEWLAND, 2007).

A contrario sensu, pesquisas apontaram a existência de um trade-off entre ganhos econômicos e direitos dos migrantes nos programas de trabalho temporário (RUHS, 2005). De fato, o ponto importante desta discussão é como evitar os problemas dos antigos programas

\footnotetext{
${ }^{76}$ Por exemplo, os acordos para a recepção de trabalhadores visitantes (guest-work ou gastarbeiter) na Alemanha entre as década de 50 e 70 (CASTLES, 2009) e o programa de atração de trabalhadores para a agricultura nos EUA - Bracero program - entre 1942 e 1964 (MORGAN, 2004).

${ }^{77}$ RIGO denomina transitionality esta estratégia que "através de uma série de barreiras temporais - tempo de estadia, prazos para a renovação dos documentos - constantemente renovam as barreiras espaciais à mobilidade" (2011).
} 
das décadas de 1950 a 1970, em especial, a permanência dos migrantes após o fim do período estipulado. Nesse sentido, abrem-se oportunidades de migração bastante restritas por áreas, ocupações, com restrições de mobilidade e de troca de empregador, e com prazos bastante limitados (CASTLES, 2006). O mecanismo é o de graduar a concessão de direitos como benefícios com o intuito de transformar as migrações em processos just in time and to the point (MEZZADRA, 2011). Assim, a mão de obra migrante deve servir às necessidades de seus mercados de trabalho e retirar-se quando não for mais necessária. Além disso, a sua temporariedade e rotatividade garantiriam que outros âmbitos da sociedade, como a identidade (resolvendo o problema da integração) e os benefícios sociais do welfare state não fossem "afetados".

Através deste esquema os Estados conseguem obter a mão de obra que precisam, sob as condições que determinam e ainda obtêm a ajuda dos países de origem no combate à imigração não-autorizada. O combate à migração irregular é, também, apresentado de forma mais amigável (CAILLAUT, 2012). Dito de outra forma, a estratégia de migração circular articulada com o discurso da migração e desenvolvimento advogadas pelas Organizações Internacionais - e apresentadas como um triple win game - não consideram os interesses e os direitos dos imigrantes (WICKRAMASKARA, 2011) e ignoram o contexto social e econômico que estruturam os migratórios, e que os submetem a relações de exploração e dominação que desafiam a concretização da ideia do triple win ${ }^{78}$.

As políticas de atração de trabalhadores qualificados atualmente também estão sendo incrementadas com a circularidade que se apresenta de forma positiva, destacando seus benefícios para todos os envolvidos no processo. Mais uma vez as Organizações Internacionais entram em cena para legitimar o discurso e garantir a prática da atração de migrantes qualificados em contraposição às críticas a respeito do brain drain, que predominavam até então. A idéia de brain drain ou "fuga de cérebros" aponta para o peso da perda de recursos humanos nos países de emigração, muitas vezes em áreas onde estes países precisam de mão de obra, inclusive para suas pretensões de desenvolvimento (PÉCOUD; LEVATINO, 2012).

$\mathrm{Na}$ verdade, a passagem do discurso da migração como problema, a ser enfrentado através da securitização de fronteiras, para o discurso da migração potencialmente benéfica

\footnotetext{
${ }^{78}$ Também os Estados de origem da imigração nem sempre obtém vantagens neste processo, principalmente quando se trata de imigração qualificada, eles podem perder trabalhadores em áreas em que enfrentam necessidade de mão-de-obra; além de muitas vezes não obter o retorno dos investimentos em educação realizados.
} 
para todas as partes, desde que gerida, é muito mais uma mudança retórica do que de atitude. A seletividade agora não se refere a quem pode e quem não pode entrar, mas também como permanecer e quando ir embora. Permanecendo o controle e a tentativa de desfrutar das migrações retirando apenas o que interessa aos Estados, qual seja, a mão de obra de que e quando necessitam.

A ausência de reconhecimento da cidadania ou a insistência em uma cidadania de base territorial-nacional permite ao Estado dirigir a vida do trabalhador imigrante, moldando-o assim, para que do seu trabalho se retire o maior lucro ao menor custo. $\mathrm{O}$ desenvolvimento das políticas migratórias tem levado a um refinamento dos mecanismos de controle e diferenciação, garantindo que aos países de destino chegue somente o desejado, ou seja, a força de trabalho dos imigrantes, mas não seus corpos, nem suas subjetividades e identidades. O que parecia impossível e foi ilustrado na famosa declaração do escritor suíço Max Frisch sobre a história da migração no seu país "nós queríamos força de trabalho, mas vieram pessoas" (s.d.), se concretiza através de controles rígidos sobre a entrada, autorizações de permanência curta e restrições de direitos, em um último estágio da transformação dos seres humanos em mercadoria.

É nesse sentido que a imigração não-autorizada resulta subversiva, pois ao impor a sua presença nos territórios que os rejeitam, os imigrantes não aceitam a sua objetificação. Fazemse sujeitos de suas próprias vidas, mas o fazem no contexto de um sistema que explora suas vulnerabilidades jurídicas e econômicas, de forma que a sua luta também é pela transformação deste sistema.

Uma política migratória que considere na sua definição a dimensão política e os conflitos de interesse em jogo necessariamente tratará os imigrantes como sujeitos de direitos, não como criminosos nem vítimas. Fará referência aos processos migratórios considerando não somente os interesses dos Estados e seus mercados de trabalho, mas principalmente as ações e demandas dos imigrantes no contexto de uma dinâmica migratória que é parte dos processos sociais cada vez mais transnacionais. As soluções simplistas que apenas mudam as cores das políticas migratórias seletivas e nacionalistas que continuam a tratar os imigrantes como mera mão de obra a ser desfrutada não são, assim, suficientes e não atuam sobre a ambivalência dos processos migratórios e as relações de exploração que muitas vezes os acompanham. Partindo do respeito e da garantia dos direitos dos imigrantes é possível aprofundar o tratamento da matéria e enfrentar as questões que continuam efetivamente a gerar exclusões e violações. 


\section{O PAPEL DOS DIREITOS HUMANOS NA CONSTRUÇÃO DE UMA} NOVA POLÍTICA MIGRATÓRIA NO BRASIL E NA TRANSFORMAÇÃO DA CIDADANIA

A discussão política sobre as migrações começou a retomar a sua relevância no Brasil na última década. No debate, ainda incipiente, é sempre presente a referência aos direitos dos migrantes não só por parte de organizações sociais, mas também de parlamentares e representantes do governo. A forte impressão que esta referência aos direitos humanos causa explica-se pois tradicionalmente, e de forma predominante ainda hoje, a discussão sobre as políticas migratórias ocorre em um ambiente onde o paradigma da soberania e do interesse nacional tenta manter o controle das migrações, por meio de políticas migratórias centradas na irregularidade ou na gestão mundial das migrações.

Isto explica que os Estados nacionais rejeitem compromissos internacionais que limitem a sua ação, fomentando, em âmbito internacional, apenas a construção de um discurso tecnocrático e aceitando fóruns de debate não vinculantes. Complementarmente, fundamentam a sua ação, seja de criminalização, restrição, seletividade e/ou tolerância, quase exclusivamente por interesses nacionais relativos ao mercado de trabalho, à segurança e à identidade nacional. São raras e amplamente dependentes da conjuntura, a linguagem de direitos e a sua garantia nessa seara (RUHS, 2011; RUHS; MARTIN, 2008). Assim, os direitos dos imigrantes assemelham-se mais a benefícios concedidos pelo Estado do que a direitos, sendo muitas vezes instrumentalizados a serviço dos objetivos de uma política seletiva.

As organizações internacionais também recorrem ao discurso dos direitos humanos dos migrantes, mas sem de fato evocar uma transformação que seja capaz de garanti-los. A ONU faz menção aos direitos humanos em suas narrativas sem aprofundar suas implicações como se viu na seção anterior. A União Europeia (UE) faz uso desse discurso para justificar a sua política de restrição à imigração e de incentivo às deportações ${ }^{79}$. A OIM refere-se aos

\footnotetext{
79 Emblemática nesse sentido, é a muito criticada Diretiva de Retorno (UE, 2008) que apresenta-se como garantidora de padrões mínimos de respeito aos direitos dos migrantes durante o processo de deportação, mas em verdade, legitima e incentiva esta prática. Em alguns casos, inclusive, referenda medidas mais graves do que as aplicáveis à época, em muitos dos países da União. Por exemplo, o limite de prazo para detenção de imigrantes sem documentos, no aguardo de seus processosde expulsão, colocado pelo art. 15, n. 5 é de seis meses, podendo ser prorrogado por no máximo mais doze meses quando o procedimento de expulsão não puder ser concluído em menos tempo, apesar dos esforços, em razão da falta de cooperação do estrangeiro ou de atrasos na obtenção da documentação necessária junto a países terceiros. O teto é estabelecido pela diretiva de retorno mas cabe a cada
} 
direitos humanos, mas promove uma política ambivalente e tecnocrática, cujo verdadeiro objetivo é o oferecimento de serviços aos Estados para a gestão das migrações, adaptando-se pontualmente às demandas estatais.

Diante disso, é importante refletir sobre o delineamento concreto do discurso de direitos humanos que está em voga no Brasil, verificando premissas e contornos de uma política migratória baseada na garantia dos direitos dos imigrantes. Como já foi apontado, a efetividade da garantia destes direitos requer a mudança de paradigma que implica reconhecer os imigrantes como sujeitos e não objetos do direito e da política. Além da rejeição à criminalização das migrações, esta proposta vai além de um simples tratamento humanitário que é vitimizador e não emancipatório. As migrações como terreno de luta pela liberdade, prática de cidadania e dos direitos humanos implicam o reconhecimento da autonomia destes sujeitos na construção de sua própria dignidade.

Essa guinada atinge, então, as bases do sistema internacional westfaliano, constituído por Estados nacionais soberanos definidos pelo conjunto de território, governo e povo. Em especial, trata-se de da superação do conceito moderno de cidadania: formal, limitado, nacionalista e excludente. A cidadania, hoje sob pressão expansiva pelos migrantes, é uma prática de liberdade e de busca por igualdade e dignidade, muito mais que um status formal de pertencimento. Essa dinâmica não é de todo nova, pois desde o início de sua história moderna e pré-moderna a cidadania foi objeto de lutas expansivas.

\subsection{Cidadania moderna, política migratória brasileira e regional}

O desenvolvimento do conceito de cidadania acompanha as mudanças político-sociais na história. A denominação é a mesma desde o período clássico na Grécia, mas seu conteúdo

Estado-Membro definir nas legislações nacionais o prazo de detenção nos centros existentes em cada um deles. Nove Estados-Membros não possuíam limite de tempo para estas detenções no momento da entrada em vigor da diretiva: Reino Unido, Dinamarca, Estônia, Finlândia, Grécia, Irlanda, Malta, Países Baixos e Suécia, mas está claro que o prazo trazido pelo instrumento europeu não opera contra as detenções longas de imigrantes. Nos países que já previam um limite, a média dos prazos praticados variava entre 30 e 60 dias e para estes a diretiva funciona, ao contrário, como legitimação para eventuais extensões, conforme o que já ocorreu na Itália. Na Itália, o máximo era de 60 dias. Com o pacchetto sicurezza que adequou a legislação italiana à diretiva de retorno, prazo subiu para 180 dias e com a Lei n. 129/2011, abriu-se a possibilidade de detenção por até 18 meses, nos casos nela descritos. Na Espanha, o prazo máximo é de 60 dias sem prorrogação pelas mesmas causas (art. 62, 2 Ley Orgánica 4/2000 com as modificações da LO 2/2009), na legislação anterior era de 40 dias e previa-se a possibilidade de que, inclusive, fosse estabelecido prazo inferior por decisão judicial. 
se modificou muito, e muitas vezes, desde então. Em sua origem, a cidadania garantia diversos direitos/privilégios a um grupo bastante restrito, uma vez que na Grécia somente os homens livres eram cidadãos; em Roma, o número de titulares dessa condição se expandiram por razões políticas e geopolíticas, ao mesmo tempo em que os direitos ligados a essa condição diminuíram. Já na modernidade, o clássico estudo de Marshall (1967) a respeito da evolução da cidadania demonstra o processo de expansão da carga de direitos levada pelo conceito de cidadania nos últimos três séculos.

A ideia da cidadania ligada à nacionalidade naturalizou-se de tal forma que parece ter se perdido a lembrança da forma como isso se construiu. Os Estados nacionais como um todo são uma ideia tão arraigada que muitas vezes é difícil pensar fora dos seus limites, o que constitui o nacionalismo metodológico. Convenciona-se apontar como 1648, o ano da Paz de Vestfália que encerrou a Guerra dos Trinta anos, como a data do surgimento do sistema internacional composto por Estados nacionais, a partir do estabelecimento do princípio moderno da territorialidade, que veio a coroar as mudanças políticas e sociais que estavam ocorrendo à época (AMARAL, 2008). Até então, o poder era organizado em grandes Impérios com diversos outros níveis de poder superpostos e sob grande influência religiosa. A partir deste período o poder passou a organizar-se sobretudo em base territorial, ou seja, os limites dos Estados definiam o âmbito de vigência de determinado poder, que era exercido de forma exclusiva e constituía o laço entre os seus destinatários, o povo de cada Estado.

Durante muito tempo, na Europa, os Estados nacionais precisavam de um povo sedentário, que pagasse impostos e estivesse disponível para defender o território nas guerras, assim, era mais fácil entrar em outro país, do que sair do seu (WIHTOL DE WENDEN, 2013). As pessoas, no entanto, não estavam mais ligadas à terra, como na época do feudalismo ${ }^{80}$. No âmbito deste processo a cidadania foi o vínculo jurídico que se estabeleceu entre o governo nacional, seu povo e seu território, com caráter hierarquizador das lealdades, além de ser excludente, estabelecendo as fronteiras da inclusão e da exclusão na comunidade política. Somente séculos depois é que, em torno dela, se desenvolveram as identidades culturais que deram lugar ao surgimento das nações, no caso da Europa (DÉLOYE, 1998).

Nesse cenário a soberania fincou as suas raízes e se desenvolveu durante a Idade Moderna. Corolários basilares do conceito de soberania eram, no plano externo, a

\footnotetext{
${ }^{80}$ Mezzadra analisa o estudo inicial na carreira de Max Weber sobre a condição dos trabalhadores agrícolas na Prússia Oriental que retrata justamente as transformações dessa passagem de uma sociedade tradicional para a sociedade moderna, onde a questão da mobilidade dos trabalhadores surge como uma questão central (MEZZADRA, 2006).
} 
independência com relação aos seus pares e, no plano interno, a exclusividade de governo sobre o seu território e o seu povo. (CASSESE, 2006). Durante muitos anos, esse poder exclusivo dos governantes estatais sobre a vida de seus súditos se apresentou também como ilimitado. De fato, a busca do Estado absoluto era criar um aparelho estatal unificado e forte para contrapor o poder da nobreza feudal descentralizada (ANDERSON, 2008). Somente a partir das Revoluções liberais este estado de coisas se modificou, os governados conseguiram estabelecer limites ao exercício do governo e adquirir direitos em face dele. Este percurso corresponde à afirmação dos direitos humanos na esfera doméstica (BOBBIO, 2004).

No medievo ainda não existia algo como a soberania. A iurisdictio (soma indistinguível de poderes de administração, produção de normas e aplicação judiciária que caracterizam o poder medieval), era de titularidade do Império, mas não só, já que os outros aneis da cadeia de entes, ordens, cidades, comunidades, corporações, também possuíam estes mesmos poderes. E o fundamento dos poderes dos entes "inferiores" não era a delegação de poder do Imperador, mas a sua própria capacidade auto-ordenante. Já na Idade Moderna, a soberania é uma qualidade que diferencia absolutamente o soberano dos demais sujeitos (COSTA, 1999).

O poder na Idade Média era concreto, na Idade Moderna é abstrato. O que fundamentava o poder no medievo era a constituição de um povo concreto. Na modernidade, o fundamento é somente um conjunto abstrato de vontades expressas por indivíduos; o que os une, como já visto, é a submissão a um mesmo soberano - que possui o monópolio do poder sobre determinado território - o que os coloca também em posição de igualdade (QUAGLIONI, 2004). Mas aqui surge, então, o problema da busca de uma nova legitimidade do poder, quando a legitimidade automática da monarquia sagrada declinava (ANDERSON, 2008).

Nesse sentido, na transição para a Idade Moderna impôs-se o novo paradigma jusnaturalista. $\mathrm{O}$ estado de natureza imaginado pelos teóricos contratualistas é uma espécie de experimento mental, não algo que exista ou tenha existido concretamente. Esta ideia permitiu, no entanto, visualizar o homem independentemente de qualquer ligação concreta. A ideia é de que o Estado, surgido do pacto social, é criado então para garantir os direitos subjetivos (de que dispõe os indivíduos em razão de sua própria existência) através da criação de direitos objetivos e esta é a sua nova legitimidade.

O pensamento político do absolutismo, no início da Idade Moderna, tem então dois principais êxitos: o individualismo e a separação das esferas da religião, da política e do direito. Tudo isso caracteriza a modernidade. Assim, paradoxalmente, descartadas as 
justificativas transcendentais, é no âmbito das relações efetivas de poder, entre súditos e governantes, que passam a ser delimitadas as garantias da liberdade humana (QUAGLIONI, 2004). Passa-se de uma ideia do direito como justa distribuição dos bens para uma ideia de direito que privilegia a noção de lei. Este é um conceito chave da concepção estatista e centralizadora do direito (GOYARD-FABRE, 2007).

Esse dualismo entre governantes e governados, que define agora os contornos efetivos do poder, também é central para o tema da cidadania. A acepção moderna de cidadania como titularidade de direitos subjetivos tem como pressupostos o Estado e a centralização jurídica. É o ente Estado que tem a prerrogativa da atribuição de tal posição jurídica. No entanto:

\footnotetext{
Uma tal simplificação de relações, pela qual a cidadania não é mais que a condição jurídica de quem faz parte de um Estado, não tem sentido, sem qualquer reserva, que na plenitude do Estado absoluto, em que a soberania é entendida como indivisível (...)(QUAGLIONI, 2004).
}

A pretensão de completude do Estado absolutista foi desde o início confrontada com formas poderosas de resistência. O Estado persiste (LINKLATER, 1998), porém com fissuras, fraturas e remodelações, que incluem a expansão do rol de direitos ligados à cidadania, pelo constitucionalismo e pela afirmação dos direitos humanos ${ }^{81}$. Ainda hoje, no entanto, a discriminação em razão da nacionalidade permanece, sob cada vez maior pressão exercida pela nova configuração dos movimentos migratórios.

O Estado moderno típico, que recebeu sua forma sistemática na era das revoluções liberais, foi uma novidade em muitos aspectos (HOBSBAWN, 1990). Dentre os problemas que esta nova forma política colocou, um dos mais candentes era o da identificação dos cidadãos ao Estado e ao sistema dirigente que, como já referido, era na Idade Média assegurada pelos corpos intermediários, como a religião, a hierarquia social, as corporações, etc. (HOBSBAWN, 1990). Assim, a cidadania moderna estabeleceu-se desde o início com

\footnotetext{
81 A constitucionalização é a configuração de determinado ordenamento jurídico como um "sistema hierarquizado de normas que condiciona a validade das normas inferiores à coerência com as normas superiores e com os princípios axiológicos nelas estabelecidos". Fala-se em constitucionalização de uma ordem internacional no sentido atribuído ao conceito por Ferrajoli, ou seja, o de que as ordens internacionais assumam os princípios de direitos internacional como vinculantes e conseqüentemente "seu projeto normativo [do direito internacional] como perspectiva alternativa àquilo que de fato acontece; validá-los como chaves de interpretação e fontes de crítica e deslegitimação do existente; enfim, planejar as formas institucionais, as garantias jurídicas e as estratégias políticas necessárias para realizá-los" e "instaur[ando] garantias idôneas que visem a tornar efetivos o princípio da paz e os direitos fundamentais, tanto dos indivíduos quanto dos povos, em seu relacionamento com os Estados". FERRAJOLI, 2002.
} 
contornos abstratos e excludentes, ao delimitar as fronteiras entre o externo e o interno, segundo vontade soberana do Estado. Até o século XVIII, no entanto, os Estados ainda não tinham a capacidade de projetar este poder na sociedade, necessitando legitimação (LINKLATER, 1998)

A ideia de patriotismo original revolucionário-popular das revoluções liberais, segundo Hobsbawn (1990), estava baseada no Estado e não era uma ideia nacionalista. A pátria, segundo o pensamento da Revolução Francesa, era a que havia sido escolhida e não era determinada pela etnia ou pela língua. Assim, o nacionalismo era uma força política separada do Estado, da qual ele se apropriou como instrumento útil na busca por um elemento de coesão do povo, além das estratégias de criação de uma comunidade imaginária através da construção de símbolos e mitos comuns (HOBSBAWN, 1990).

Enquanto o patriotismo estatal tinha uma tendência amplamente includente - era cidadão que decidia adotar a pátria - , o nacionalismo era excludente e baseava-se na língua, na etnia e outros critérios de diferenciação. O risco de criar um contranacionalismo ao excluir parte da população não gerou problemas imediatos já que o próprio processo de modernização incentivou a homogeneização e assimilação dos grupos minoritários, sobretudo pelo estabelecimento de uma língua nacional (HOBSBAWN, 1990).

Existem divergências sobre a origem do nacionalismo, em especial sobre o grau de concepção estratégica por parte dos Estados. A ideia de comunidades imaginadas de Anderson (2008) quer enfatizar que o processo de afirmação dos nacionalismos não foi um expediente maquiavélico dos Estados para estabelecer laços com a sua população, mas que diversos outros fatores influenciaram este processo, como a vernaculização do idioma, o surgimento da imprensa e as novas relações sociais estabelecidas pelo capitalismo. $\mathrm{O}$ dado subjetivo, que resulta de um processo imaginativo responde à necessidade de forjar um sentimento de pertencimento a uma comunidade que, neste caso, é imaginada, pois em verdade, cada indivíduo jamais conhecerá a maior parte dos seus co-membros da comunidade nacional.

De toda forma, construiu-se ou colheu-se a ideia de nação - cuja historicidade não pode ser esquecida - na busca de assentar um povo, delimitando-o através de laços constituídos, muitas vezes impostos através de um processo de homogeneização, para formar uma nação. O nacionalismo foi a abstração capaz amalgamar o grupo, e muitas vezes se impôs de forma violenta. Os elementos teóricos do Estado: território delimitado, povo e governo autônomo, são assim atendidos. Neste processo de homogeneização, minorias foram marginalizadas e estrangeiros excluídos (LINKLATER, 1998). Assim, a nacionalidade é uma 
construção diferenciadora: constrói-se o amálgama, a mobilização da coletividade de cidadãos, a partir da diferenciação de outros grupos, de modo que a cidadania nacional é excludente desde as suas origens. Somente no período das revoluções liberais é que a esta começou a ganhar contornos de direitos

Este preenchimento da cidadania na modernidade com direitos políticos, civis e sociais universais $^{82}$ ocorreu através de lutas resultantes das tensões sócio-políticas, às quais a expansão das garantias jurídicas respondeu. À época, a tensão originava-se do aumento do poder estatal dentro das comunidades políticas homogêneas por eles moldadas, primeiramente frente às interpelações estatais e posteriormente frente às crescentes desigualdades capitalistas (LINKLATER, 1998), o que corresponde à afirmação dos direitos civis, políticos e sociais.

Hoje também há uma tensão que conduz ao tema da exclusão e da diferenciação operacionalizadas pela própria cidadania nacional jurídico-formal com relação aos cidadãos não reconhecidos como tais. Os migrantes praticam a cidadania quotidianamente e, por diversas formas, reivindicam o seu reconhecimento frente aos Estados Nacionais. Os Estados Democráticos de Direito ocidentais apresentam-se fraturados e deslegitimados em sua tarefa de garantir os direitos subjetivos, ao manter esta diferenciação entre cidadãos regulares e irregulares dentro do mesmo território.

Nessa lógica, a cidadania torna-se um privilégio (ou um status ontológico passivo ${ }^{83}$ ): ou se é, ou não se é, cidadão. Os requisitos para a aquisição da nacionalidade com base no jus sanguinis, no jus soli ou em uma combinação destes, têm sua origem na história (ANDERSON, 2008), mas operam hoje como uma fatalidade. E a possibilidade de naturalização só vem a confirmar o convite a entrar na "comunidade imaginada" que ela representa (ANDERSON, 2008) pressupondo o sedentarismo do povo, e menosprezando a configuração de mobilidade humana trazida pelas migrações.

A lógica diferenciadora e hierarquizante de grupos, os nacionais e os não-nacionais, remete assim às origens da configuração dos Estados-nação. Tal lógica sempre foi necessária ao funcionamento do sistema capitalista, inicialmente operando internamente ao conceito de cidadania, por meio de diferenciações de raça, classe social, gênero, etc. Hoje, a grande presença de imigrantes a quem se nega o status formal de cidadão faz com que o próprio reconhecimento ou não da cidadania ou a atribuição de sub-cidadanias causem diferenciações também funcionais ao sistema capitalista.

\footnotetext{
${ }^{82}$ A universalidade pode ser questionada mesmo internamente à cidadania nacional em razão de seu caráter formal que marginaliza os diferentes.

${ }^{83}$ Ver HERRERA FLORES; RODRIGUEZ PRIETO, 2003.
} 
A cidadania nacional jurídico-formal é o status que confere aos indivíduos a titularidade de direitos políticos, em especial o direito de votar e ser votado. Os direitos políticos e a participação política em geral foram historicamente espaços para a conquista da cidadania substantiva, como se viu. Os migrantes, ainda que não possuam esses direitos, praticam a cidadania e buscam a efetivação de seu direito a levar adiante suas lutas por sua própria concepção de dignidade humana (HERRERA FLORES, 2005).

As concepções cosmopolitas liberais e socialistas de Kant e Marx divergem a respeito do conceito de universal e da forma de sua operacionalização. Enquanto o primeiro pugna por comunidades políticas, que podem manter a forma de Estado, ancoradas em ideias de liberdade e igualdade de conteúdo absoluto e imutável, o segundo traz o foco para as précondições sociais e econômicas para o alcance da liberdade humana, considerando que para alcançar este objetivo é necessária a reconstrução total da vida econômica e social. Sem aprofundar estas questões político-filosóficas das mais profundas, o desafio está em construir uma "transição para uma condição em que soberania, territorialidade, nacionalidade e cidadania não [sejam] colocadas juntas para definir a natureza e o propósito da associação política" (LINKLATER, 1998).

Os direitos humanos, como processos, representam "as dinâmicas e lutas históricas contra a violência das diferentes manifestações de poder tanto das burocracias públicas como das privadas" (HERRERA FLORES, 2005). A busca pela efetivação dos direitos humanos é permanente frente aos abusos do poder estatal e às desigualdades intrínsecas ao sistema capitalista entre nacionais e imigrantes. Ainda que as diferenciações internas (como o racismo) e externas (o nacionalismo) aos nacionais tenham origens diferentes (ANDERSON, 2008), hoje mais que em qualquer época elas se articulam e operam conjuntamente.

Os grupos diferenciados e marginalizados ainda hoje lutam por leis e políticas que enfrentem estas exclusões, a exemplo do que ocorre não só no Brasil com os grupos que denunciam e lutam contra o racismo, como obstáculo à efetivação de direitos para os negros diante de sua exclusão histórica. A ideia de raça, critério de diferenciação que opera hoje dentro da cidadania formal, reage à ideia Iluminista de visão unitária da humanidade (SCHWARCZ, 1993). Os migrantes de hoje em grande parte dos casos, se negros, indígenas e pobres, acumulam a exclusão substantiva e formal da cidadania. Estas lutas são compartilhadas, travadas dentro do sistema capitalista.

O Brasil tem um histórico de fragilidade e exclusão na conformação da sua cidadania substantiva e formal em razão de seu passado de dominação colonial baseado no latifúndio e na escravidão com grande prejuízo para o sentido de igualdade; da instrumentalização do 
poder público e do descaso com a educação no período colonial (CARVALHO, 2011). Além disso, contamos com um mito de abertura à imigração em razão do grande volume de imigrantes que chegaram a partir da segunda metade do século XIX. Assim, os critérios de exclusão internos à nossa cidadania e o nacionalismo como amálgama da sociedade também atingiram este processo ${ }^{84}$.

No Brasil, a ordem cronológica e a lógica da aquisição dos direitos civis, políticos e sociais da teoria de Marshall não se verificou. A construção do conceito moderno de cidadania não ocorreu da forma linear, descrita em seu estudo sobre a Inglaterra, em todas as partes do mundo. Naquela realidade, a garantia dos direitos civis que representavam defesas contra a arbitrariedade do Estado foi o que permitiu aos indivíduos buscar os seus direitos políticos. Graças ao exercício dos direitos políticos é que puderam, então, escolher os seus governantes e reivindicar outros direitos frente às desigualdades geradas pelo sistema capitalista, os direitos sociais. Não foi exatamente assim que as coisas ocorreram por aqui.

Após a Independência, em 1822, o direito ao voto já era acessível à grande parte da população masculina e livre. A escravidão, no entanto, matinha-se, de modo que nem mesmo os direitos civis eram garantidos a toda a população (CARVALHO, 2011). O próprio direito ao voto era restrito à elite que, certamente, não tinha grande interesse em transformações políticas.

Uma organização política da sociedade só começou a ocorrer a partir do fím da Primeira República, processo que foi interrompido ou dificultado ao menos duas vezes durante os períodos ditatoriais (CARVALHO, 2011). A partir da década de 30, os brasileiros também passaram a contar com direitos sociais como os trabalhistas e sindicais, mas a marcha destes também foi diferente. Resultaram de leis pensadas pelos governantes e não da ação política e sindical independente, de modo que os benefícios sociais não eram vistos como direitos, mas como favores do Estado e contribuíam para a formação de cidadãos passivos e dependentes (CARVALHO, 2011).

A história das políticas e leis de imigração no Brasil é intrinsecamente ligada à história da cidadania brasileira. Alguns anos antes da abolição da escravatura, devido à lei do ventre livre e às pressões inglesas pela abolição, o Estado passou a promover a imigração de colonos europeus para trabalhar nas fazendas e para povoar áreas ainda não exploradas.

Nas discussões a respeito do imigrante ideal (SOUZA, 2000), além da aptidão para o trabalho na agricultura, o potencial de assimilação era critério central de análise e a religião

${ }^{84}$ Ver: SCHILLING, 2002. 
católica e a origem latina reforçaram a preferência pelos italianos. No início das políticas de incentivo à imigração, ainda no período monárquico, o discurso racial não era explícito, mas na busca do imigrante ideal, os europeus, em especial os alemães eram considerados os mais aptos para o objetivo da colonização. A política era eminentemente seletiva, de acordo com os objetivos estabelecidos pelo Estado. Assim, agricultores que emigrassem em família, que tivessem "amor ao trabalho" e respeito às autoridades eram os escolhidos (SEYFERTH, 2002). Considerava-se que os indígenas e os negros habitantes do território brasileiro não preenchiam essas características e eram, assim, uma alternativa descartada.

Pode-se dizer que o Brasil estabeleceu uma cidadania colonial como lógica de diferenciação, excluindo os negros escravizados e os índios nativos. A partir da Declaração de abolição da escravatura a diferenciação foi internalizada, o que perdura até hoje. Os negros não eram considerados sujeitos de direitos até 1888, ano da abolição da escravatura, e, mesmo após a abolição, não houve incentivos para a sua inserção social. Ao contrário, ainda hoje se discute a adoção de políticas que revertam esta situação.

Da mesma forma, os índios até recentemente, segundo o Código Civil de 1916 revogado em $2002^{85}$, não possuíam capacidade civil plena ${ }^{86}$. Nativos do território, hoje brasileiro, eles foram praticamente dizimados pelos colonizadores. Os que sobreviveram migraram para o interior e a sua identidade não foi reconhecida pela "nação" brasileira. De fato, eram considerados indígenas somente quando não tivessem contato com a "civilização" de origem europeia e, neste caso, recebiam uma proteção do Estado. Ao inserir-se na sociedade brasileira, deixavam de ser reconhecidos como indígenas, em sua identidade particular.

No fim do século XIX, as discussões sobre a política migratória foram invadidas pelos discursos racialistas e o objetivo de branqueamento da população brasileira se tornou mais explícito. Em 1890 ficou bastante claro este objetivo, além dos ligados à economia. Assim, o art. $1^{\circ}$ do Decreto 528 de 1890 dispunha que era inteiramente livre a entrada de trabalhadores, exceção feita aos indígenas da Ásia ou da África, que necessitavam autorização do Congresso Nacional. Com essa política, entre 1877 e 1930, o Brasil recebeu cerca de quatro milhões de imigrantes (LEVY, 1974).

Tornava-se proeminente na época a crença na existência de "raças" distintas, quase espécies diversas, cuja mistura resultava em degeneração, uma vez que os mestiços herdavam

\footnotetext{
${ }^{85}$ Segundo o parágrafo único do art. 4 do CC/2002: A capacidade dos índios será regulada por legislação especial. Ver também MOURA, 2009.

${ }^{86}$ Art. 6, III CC/1916.
} 
todas as características negativas de cada "raça" (SCHWARCZ, 1993). Logo, "[e]sse saber sobre as raças implicou (...) um ideal 'político', um diagnóstico sobre a submissão ou mesmo a possível eliminação das raças inferiores" (SCHWARCZ, 1993 p. 60).

A política de branqueamento da população brasileira insere-se nesse contexto de expansão das ideias de autores darwinistas sociais, para quem o progresso das sociedades não era um estágio que seria atingido mais cedo ou mais tarde, mas era restrito às sociedades puras, sem miscigenação. No Brasil, reinterpretou-se essa teoria para não estabelecer a inviabilidade da nação mestiça, mas "apenas" hierarquias e diferenciações (SCHWARCZ, 1993), buscando um aumento do elemento branco que através da miscigenação acabaria por eliminar as características negativas das "raças inferiores" (SEYFERTH, 2000).

À época, a imigração maciça era estimulada pelo Estado, mas, além daqueles selecionados como imigrantes ideais a cada momento, até a primeira metade do século XX não havia dificuldades para qualquer europeu entrar no país. Assim, os alemães que já haviam perdido esta posição puderam continuar a entrar sem dificuldades. Na década de 1930, o fortalecimento das posições nacionalistas é que destrona os alemães, acusados de não se deixarem assimilar. Esse é o momento em que a formação racial do Brasil incide sobre as políticas de migração e ainda que o europeu continue a ser considerado como raça superior, a nação brasileira mestiça os julga negativamente pela manutenção de sua língua, religião e cultura, considerando que tais atitudes os impediam de tornar-se brasileiros (SEYFERTH, 2000).

Hoje, dentro do contexto da integração regional, é juridicamente mais fácil um sulamericano estabelecer-se no Brasil do que um europeu ${ }^{87}$. No entanto, o imigrante ideal presente no imaginário do Brasil ainda guarda resquícios do passado. Não existem mais disposições legais dando preferência a uma ou outra nacionalidade ou grupo étnico e, em muitos casos, a resistência à abertura refere-se mais a questões de reserva de mercado do que identitárias $^{88}$. Ainda assim, alguns estereótipos permanecem (SCARIOT, s.d). A compreensão de que quem migra para o Brasil deve contribuir para o desenvolvimento nacional e, portanto, deve ser qualificado e não deve ser pobre faz ligação direta com os estereótipos muito presentes no Brasil de que negros e índios contribuíram para o subdesenvolvimento do Brasil,

\footnotetext{
${ }^{87}$ Sobre os Acordos de Residência do Mercosul, ver p. 92.

${ }^{88}$ As reações ao Programa Mais Médicos são bastante ilustrativas. O rechaço da opinião pública atingiu de forma especial os médicos cubanos (BRUM, 2013). É necessário, no entanto, diferenciar as reações em geral, das reações dos médicos brasileiros e suas entidades de classe, que rechaçam o programa em si e apostam no REVALIDA como instrumento de reserva de mercado e de manutenção de seus privilégios, ainda que haja uma relação dialógica entre elas. Ver também as ADI 5035 e 5037 apresentadas por associações e sindicatos médicos contra o programa. Ver p. 104.
} 
pois não seriam aptos ao trabalho, ao conhecimento e ao progresso como os europeus ${ }^{89}$. Assim, os grupos imigrantes de maior presença atualmente, os latinoamericanos, enfrentam o desafio do reconhecimento e da valorização de sua cultura, ou seja, a superação da cidadania colonial.

A naturalização das diferenças via teoria das raças do século XIX buscou "retirar a diversidade humana do reino incerto da cultura para localizá-lo na moradia segura da ciência determinista do século XIX" (SCHWARCZ, 1993). No caso das diferenças de nacionalidade, o abrigo seguro é a lei e a soberania que legitimam essas diferenciações. Raça e nacionalidade são apresentadas como características ontológicas dos indivíduos. Nega-se assim a sua subjetividade, os seus desejos, a sua individualidade.

Em 1934 e 1937, as Constituições responderam, então, a este medo do estrangeiro frente ao projeto de nacionalização. A concentração de imigrantes de mesma nacionalidade estrangeira e isolados nos núcleos coloniais gerava o temor no governo central do desenvolvimento de comunidades paralelas (LOPES, 2009). O art. 121 da Constituição de 1934 respondia a esta preocupação e previa:

\footnotetext{
$\S 6^{\circ}$ - A entrada de imigrantes no território nacional sofrerá as restrições necessárias à garantia da integração étnica e capacidade física e civil do imigrante, não podendo, porém, a corrente imigratória de cada país exceder, anualmente, o limite de dois por cento sobre o número total dos respectivos nacionais fixados no Brasil durante os últimos cinquenta anos.

$\S 7^{\circ}$ - É vedada a concentração de imigrantes em qualquer ponto do território da União, devendo a lei regular a seleção, localização e assimilação do alienígena.
}

A presença de imigrantes europeus nas fábricas também trazia novas ideias, práticas políticas e de organização social, o que preocupava o governo (CARVALHO, 2011). Para evitar o seu predomínio e expansão, a lei de sindicalização de $1931^{90}$ restringia à proporção de $1 / 3$ e à residência de 20 anos ou mais no Brasil, a ocupação de cargos de administração dos sindicatos por estrangeiros.

A Constituição de 1937 mantinha o sistema de cotas em seu art. 151 e o Decreto-Lei 406 de 1938, primeira lei sobre estrangeiros do Brasil, possuía um capítulo, o VIII, intitulado

\footnotetext{
${ }^{89}$ Ver, por exemplo, BENITES, 2012; ORIÁ, 1996; VIANA e LIMBERTI, s.d.

${ }^{90}$ Decreto $^{\circ}{ }^{\circ} 19.770$, de 19 de Março de 1931. O artigo 354 da Consolidação das Leis do Trabalho, promulgada em 1943 segue nesta linha ao dispor: A proporcionalidade será de 2/3 (dois terços) de empregados brasileiros, podendo, entretanto, ser fixada proporcionalidade inferior, em atenção às circunstâncias especiais de cada atividade, mediante ato do Poder Executivo, e depois de devidamente apurada pelo Departamento Nacional do Trabalho e pelo Serviço de Estatística da Previdência do Trabalho a insuficiência do número de brasileiros na atividade de que se tratar.
} 
Concentração e Assimilação, o qual determinava que "nenhum núcleo colonial (...) será constituído por estrangeiros de uma só nacionalidade", fixando os percentuais da composição destes núcleos com brasileiros e estrangeiros.

O Decreto-Lei 7967 de 1945, segunda norma a tratar de imigração, reiterava o objetivo de branqueamento presente nas Constituições anteriores e inseria a defesa do trabalhador nacional como objetivo ${ }^{91}$. Tais propósitos permaneceram após a Constituição de 1946, que apenas referia o interesse nacional definido em lei ${ }^{92}$.

Tanto na Constituição de 1967 (art. 8, XVII, p) como na de 1988 (art. 22, XV), o objetivo da política migratória se ausenta, restando a competência da União para legislar sobre emigração e imigração, entrada, extradição e expulsão de estrangeiros (LOPES, 2009). Se na Constituição de 1967 isso representou uma abertura em relação às disposições racistas anteriores, na Constituição de 1988, democrática e garantista, a questão da imigração - em um momento em que não havia grandes movimentos migratórios para e a partir do Brasil foi ignorada.

$\mathrm{Na}$ ausência de objetivos migratórios definidos constitucionalmente nas duas últimas Constituições, a lei ordinária aplicável aos imigrantes, qual seja a Lei 6185 de 1980, conhecida como Estatuto do Estrangeiro, é que cumpriu esta tarefa desde a sua promulgação. Diferentemente das anteriores, esta lei não fala de imigrantes ou de imigração. O objetivo de colonização já não existe na política nacional, trata-se, então, de regular a entrada de estrangeiros. Assim, o cerne dessa legislação é a defesa do mercado de trabalho nacional e da segurança nacional. A lei não prevê incentivos nem facilitações à imigração. O favorecimento à recepção de mão de obra especializada configura-se apenas pela existência de um canal de migração regular, mediante cumprimento de vasta burocracia, enquanto para os trabalhadores "não-especializados" a imigração de forma regular torna-se praticamente impossível.

Desde a aprovação desta legislação por decurso de prazo $^{93}$ (RAMOS, 2008) há mais

\footnotetext{
${ }^{91}$ Decreto-Lei 7967 de 1945: art. $2^{\circ}$ Atender-se-á, na admissão dos imigrantes, à necessidade de preservar e desenvolver, na composição étnica da população, as características mais convenientes da sua ascendência européia, assim como a defesa do trabalhador nacional.

92 Constituição de 1946: art 162: A seleção, entrada, distribuição e fixação de imigrantes ficarão sujeitas, na forma da lei, às exigências do interesse nacional. Parágrafo único: Caberá a um órgão federal orientar esses serviços e coordená-los com os de naturalização e de colonização, devendo nesta aproveitar nacionais.

${ }^{93}$ Segundo previsão do art. 51 da Constituição de 1967 (com emenda em 1969). Este instituto ficou vigente até a emenda constitucional n. 22 de 1982. Art. 51. O Presidente da República poderá enviar ao Congresso Nacional projetos de lei sôbre qualquer matéria, os quais, se o solicitar, serão apreciados dentro de quarenta e cinco dias, a contar do seu recebimento na Câmara dos Deputados, e de igual prazo no Senado Federal. $\S 1^{\circ}$ A solicitação do prazo mencionado nêste artigo poderá ser feita depois da remessa do projeto e em qualquer fase de seu andamento. $\S 2^{\circ}$ Se o Presidente da República julgar urgente o projeto, poderá solicitar que a sua apreciação seja feita em sessão conjunta do Congresso Nacional, dentro do prazo de quarenta dias. $\S 3^{\circ} \mathrm{Na}$ falta de deliberação
} 
de 30 anos, o Brasil, o mundo e as dinâmicas migratórias mudaram muito. Apesar disso, a lei segue vigente para a matéria. Nem mesmo a redemocratização brasileira e a promulgação de uma nova Constituição representaram de plano uma mudança no tratamento jurídico dos imigrantes. Durante o período de vigência da Lei 6815/1980, o Brasil deixou de ser um país de imigração para se tornar um país de emigrantes. Antes da crise financeira de 2008, estimava-se existiam cerca de três milhões de brasileiros vivendo no exterior (OIM, 2009). Com o retorno de muitos deles, hoje este número, ainda que incerto, certamente é menor (GIRALDI, 2013). Mais recentemente, na última década, nota-se uma retomada dos fluxos de imigrantes para o Brasil, agora com significativa presença de sul-americanos (SILVA, 2007), o que transforma o país em um país de emigrantes e imigrantes, simultaneamente.

A realidade de muitos migrantes, ou não encontra resposta legal ou encontra respostas incompatíveis com a nova ordem social, política e jurídica vigentes, gerando exclusões e violações de direitos. A restritividade à imigração estabelecida pelo Estatuto do Estrangeiro, da mesma forma que acontece com as outras legislações restritivas no mundo, não tem a capacidade de evitar a entrada de imigrantes, mas favorece o tráfico de pessoas, a exploração laboral e diversas outras violações de direitos humanos que decorrem da falta de documentos, além de permitir o estabelecimento de hierarquias e a seletividade.

Assim, o Estatuto do Estrangeiro choca-se com a nova ordem social e política transnacional pois as trocas através das fronteiras, e a fluidez entre o interno e o externo, promovem a criação de um novo espaço social não confinado às fronteiras do território nacional, com um povo que reivindica maior mobilidade e pertencimentos múltiplos. Este povo e estas dinâmicas não encontram reconhecimento em uma legislação que trata o imigrante com desconfiança, limitando a sua participação na sociedade.

A prática da cidadania pelos migrantes indocumentados é irregularizada pelas normas brasileiras vigentes: os imigrantes não possuem direitos políticos (nesse sentido, os art. $14 \S 2^{\circ}$ e $\S 3^{\circ}$, I e art. $22, \S 2^{\circ}$ da $\mathrm{CF} / 88^{94}$; art. 107 da Lei $6815 / 80^{95}$ ) e seus direitos sindicais são

dentro dos prazos estipulados nêste artigo e parágrafos anteriores, considerar-se-ão aprovados os projetos. $\S 4^{\circ} \mathrm{A}$ apreciação das emendas do Senado Federal pela Câmara dos Deputados far-se-á, nos casos previstos nêste artigo e em seu $\S 1^{\circ}$, no prazo de dez dias; findo êste, serão tidas por aprovadas, se não tiver havido deliberação. $\S 5^{\circ}$ Os prazos do artigo 48, dêste artigo e de seus parágrafos e do $\S 1^{\circ}$ do artigo 55 não correrão nos períodos de recesso do Congresso Nacional. $\S 6^{\circ} \mathrm{O}$ disposto nêste artigo não se aplicará aos projetos de codificação.

${ }_{94}$ Art. 14. A soberania popular será exercida pelo sufrágio universal e pelo voto direto e secreto, com valor igual para todos, e, nos termos da lei, mediante: $\S 2^{\circ}$ - Não podem alistar-se como eleitores os estrangeiros e, durante o período do serviço militar obrigatório, os conscritos. $\S 3^{\circ}$ - São condições de elegibilidade, na forma da lei: I - a nacionalidade brasileira;

${ }^{95}$ Art. 107. O estrangeiro admitido no território nacional não pode exercer atividade de natureza política, nem se imiscuir, direta ou indiretamente, nos negócios públicos do Brasil, sendo-lhe especialmente vedado: I - 
restritos (ver art. 106, VII da Lei $6815 / 80^{96}$ ). A indocumentação também dificulta a inserção social destas pessoas, precisando recorrer a outras formas de solidariedade privada quando seus direitos são restringidos. Apesar disso, em sua presença no território brasileiro, reconhecidos ou não, desenvolvem as suas vidas. Nesse espaço transnacional que criam, eles praticam a cidadania - com todas as contradições e implicações para a democracia que possa ter uma cidadania não-reconhecida.

A nova ordem jurídica com que se choca o Estatuto do Estrangeiro é representada por excelência pela Constituição de 1988, redigida no período da redemocratização do país, e portadora de um grande elenco de direitos fundamentais ao longo do seu texto, em especial no art. $5^{\circ}$. A esta se soma a assinatura pelo Brasil de diversos tratados internacionais de direitos humanos. É evidente a incompatibilidade do Estatuto do Estrangeiro, elaborado na época da ditadura militar sob inspiração da doutrina da segurança nacional, com esta nova ordem normativa. Aquela lei trata o estrangeiro com um elemento perigoso, o que fundamenta grande parte das vedações do art. 106, incluídas a impossibilidade de ser proprietário de empresa jornalística ou de ser responsável pela linha editorial destas, como proteção à propagação de idéias nocivas ao interesse nacional (FRAGA, 1985). É a mesma concepção securitária que justificou as previsões de controle e de informação de cada movimento dos estrangeiros às autoridades nacionais, como disposto nos arts. 45 a 47 sobre as necessárias comunicações das Juntas Comerciais, Cartórios de Registro Civil e imobiliárias, locadores e estabelecimentos de hospedagem ao $\mathrm{MJ}$ a respeito das mudanças na situação dos estrangeiros por eles registradas (FRAGA, 1985).

Obviamente, as disposições incompatíveis com a Constituição deveriam ser derrogadas, o que ainda não ocorreu, passados trinta e quatro anos da promulgação do texto constitucional. Alguns projetos de lei já foram apresentados com vistas a substituir o Estatuto do Estrangeiro, sem obter sucesso, como se verá a seguir. Algumas questões também foram levadas ao Judiciário, como o direito dos imigrantes ao Benefício de Prestação Continuada

organizar, criar ou manter sociedade ou quaisquer entidades de caráter político, ainda que tenham por fim apenas a propaganda ou a difusão, exclusivamente entre compatriotas, de idéias, programas ou normas de ação de partidos políticos do país de origem; II - exercer ação individual, junto a compatriotas ou não, no sentido de obter, mediante coação ou constrangimento de qualquer natureza, adesão a idéias, programas ou normas de ação de partidos ou facções políticas de qualquer país; III - organizar desfiles, passeatas, comícios e reuniões de qualquer natureza, ou deles participar, com os fins a que se referem os itens I e II deste artigo. Parágrafo único. O disposto no caput deste artigo não se aplica ao português beneficiário do Estatuto da Igualdade ao qual tiver sido reconhecido o gozo de direitos políticos.

96 Art. 106. É vedado ao estrangeiro: VII - participar da administração ou representação de sindicato ou associação profissional, bem como de entidade fiscalizadora do exercício de profissão regulamentada; 
(BPC) previsto na Constituição Federal (art. 203, V) e na Lei Orgânica de Assistência Social LOAS (art. 20 da Lei 8742/93). São inúmeras as ações judiciais sobre o tema e a jurisprudência tem se mostrado favorável à sua concessão, contra o entendimento dos órgãos governamentais que o restringem aos brasileiros natos e naturalizados ${ }^{97}$. Apesar de todos estes movimentos, o paradigma securitário e uma enorme quantidade de disposições normativas ultrapassadas sobre o tema permanecem.

Os dois projetos de lei atualmente em tramitação que visam a derrogar completamente a Lei 6815/1980 são o PL n. 5655/2009 na Câmara dos Deputados e o PLS n. 288/2013 no Senado ${ }^{98}$. Além destes, existem alguns outros que modificam disposições pontuais do Estatuto do Estrangeiro ${ }^{99}$. Em 2013 o MJ, por sua Secretaria Nacional de Justiça, criou uma Comissão de Especialistas ${ }^{100}$ para elaborar o anteprojeto de uma nova lei de migrações, apresentado em Audiência Pública no dia 06 de maio de 2014 e aberto a receber contribuições da sociedade civil até o dia 23 de maio. Ainda não é clara a estratégia que será adotada pelo MJ quando o documento for finalizado, uma vez que o PL n. 5655/2009 é também de autoria do Executivo, e poderá ser substituído ou retirado.

No PL n. 5655/2009 os avanços são parcos e há até mesmo retrocessos. À parte de alguns avanços como o reconhecimento explícito de alguns direitos (já existentes, segundo interpretação constitucional) para todos (independentemente do status migratório), como o direito à educação, à saúde e à remuneração pelo trabalho realizado (art. 5); há poucos progressos em termos de garantias civis, sociais, políticas e à mobilidade. É certo que nos artigos introdutórios faz-se menção aos direitos humanos (art. 2), mas estes não se traduzem no restante do texto legislativo. O PLS 288/2013 é mais garantista em termos de direitos humanos, mas não toca na questão institucional de iniciativa exclusiva do Executivo (art. 61 $\mathrm{CF} / 88)^{101}$.

\footnotetext{
97 Aguardam julgamento, no TRF da 3 região, a Ação Civil Pública n. ${ }^{\circ}$ 0021229-88.2004.4.03.6100 e, julgamento final no STF com repercussão geral, o Recurso Extraordinário n. ${ }^{\circ} 587.970$ de uma ação individual. Ver BARALDI; ALMEIDA; WALDMAN, no prelo.

${ }^{98}$ Em 2005, um Anteprojeto foi apresentado pelo MJ um Anteprojeto de Lei para substituir o Estatuto do Estrangeiro. Diante da reação negativa, em especial das organizações que atuam junto aos migrantes, o Projeto foi descartado. Ver SILVA, 2006.

${ }^{99}$ Por exemplo, o PL 3637/2008 - Altera a Lei $\mathrm{n}^{\text {o }}$ 6.815, de 19 de agosto de 1980, para permitir a concessão de visto a estrangeiro portador de documento de viagem emitido por governo não reconhecido pelo Brasil. Já o PL 1499/2007 - Estabelece a concessão de visto temporário para os estrangeiros que vierem trabalhar temporariamente em eventos esportivos de nível internacional. O PL 3059/2008 recentemente transformado na Lei Ordinária 12968/2014, altera o Estatuto do Estrangeiro, visando a criação de procedimento alternativo para a obtenção de visto de turista. E o PL 3772/2008 transformado na Lei 12878/2013, altera a Lei no 6.815, de 19 de agosto de 1980, oferecendo nova disciplina à prisão preventiva para fins de extradição.

${ }^{100}$ Ver Portaria MJ n. 103 de 2013

${ }^{101}$ Sobre a divisão de competências sobre a matéria migratória, ver p. 95 e sobre a discussão sobre a adequação
} 
Complementando o quadro normativo sobre o tema, o Brasil e a Venezuela, são os únicos países do Mercosul a não ter ratificado a Convenção da ONU sobre Trabalhadores Migrantes de 1990. Como já se viu, a Convenção foi enviada para análise e votação do Congresso sobre a sua ratificação em dezembro de 2010, mas sua tramitação está interrompida aguardando a formação de uma Comissão Especial para analisá-la. Apesar dos seus limites ${ }^{102}$, se aprovada com status constitucional, tornará mais explícitas as inconstitucionalidades do Estatuto do Estrangeiro ou de uma nova lei, caso prospere um Projeto semelhante ao PL 5655/2009.

Até o momento, o Estado brasileiro tem respondido à realidade migratória apenas $a$ posteriori, de forma precária e pontual, por meio de Anistias - concedidas em 1981, 1988, 1998 e $2009^{103}$-, de grande importância no quotidiano dos imigrantes já presentes no território brasileiro, mas que juridicamente são apenas um paliativo que não muda o paradigma da irregularidade. Caso seja mantida esta estratégia, daqui a dez anos, será necessária uma nova anistia. No mesmo sentido, se coloca a solução ad hoc adotada para os casos de refúgio que aguardam há mais de 6 meses para julgamento no Comitê Nacional de Refugiados (CONARE), os quais foram enviados ao CNIg para concessão de residência $\left(\right.$ GOVERNO..., 2013) ${ }^{104}$.

A experiência mais inovadora em termos de política migratória no Brasil ocorre no âmbito dos processos de integração regional. Os Estados da região reagiram às tendências de criminalização dos imigrantes e às políticas restritivas dos países do hemisfério Norte $^{105}$, hoje agravadas pelos problemas econômicos, políticos e sociais que os países desenvolvidos enfrentam atualmente. Os países sul-americanos promovem o discurso do direito à migração, da abordagem integral do fenômeno migratório, do respeito irrestrito dos direitos humanos destas pessoas e da construção de uma cidadania sul-americana. Segundo o Tratado Constitutivo da Unasul, são objetivos específicos da organização:

i) a consolidação de uma identidade sul-americana através do reconhecimento progressivo de direitos a nacionais de um Estado Membro residentes em qualquer

\footnotetext{
deste quadro institucional, ver p. 109 e 110.

${ }^{102}$ Ver ponto 1.3 .

${ }^{103}$ Ver respectivamente a Lei n. ${ }^{\circ}$ 6.964, de 9 de dezembro de 1981 que modificou o Estatuto do Estrangeiro; a Lei n. ${ }^{\circ} 7.685$, de 2 de dezembro de 1988; e a Lei n. ${ }^{\circ} 9.675 / 98$, regulamentada pelo Decreto n. ${ }^{\circ} 2.771$, de 07 de setembro de 1998 e a Lei 11.961 de 02 de julho de 2009.

${ }^{104} \mathrm{O}$ envio dos casos do CONARE ao CNIg é feito com base na Resolução CONARE n. 13 de 23 de março de 2007.

${ }^{105}$ Os países sul-americanos se manifestaram através de uma Declaração da União das Nações Sul-Americanas sobre a Diretiva de Retorno da União Européia (UE), emitida em 04 de julho de 2008
} 
outro Estado Membro, com o objetivo de alcançar uma cidadania sul-americana;

j) o acesso universal à seguridade social e aos serviços de saúde;

k) a cooperação em matéria de migração, com enfoque integral e baseada no respeito irrestrito aos direitos humanos e trabalhistas para a regularização migratória e a harmonização de políticas (Art. $3^{\circ}$, Tratado de Brasília, 2008).

O tratado está em vigor desde 11 de março de 2011. Os doze Estados Partes do Tratado, já depositaram seus instrumentos de ratificação ${ }^{106}$. A organização foi criada em 2008 apresentando novidades no âmbito da integração regional, especialmente relativos à forte componente política de sua propostas (VENTURA; BARALDI, 2008), construída a partir de um um discurso de identidade regional marcante (MEUNIER; MEDEIROS, 2013). A Unasul se pronunciou prontamente quando eclodiu a crise boliviana das províncias autonomistas em 2008 e agiu da mesma forma com relação ao ataque ao presidente do Equador, Rafael Correa, em 2010 (DABÈNE, 2012). Também rechaçou publicamente a adoção pela UE da Diretiva de Retorno, chamada "diretiva da vergonha" (UNASUL, 2008) ${ }^{107}$. Tornar efetivos esses comandos do Tratado constitutivo é o desafio atual. O tratamento proposto para a imigração na América do Sul reveste-se de grande relevância, pois a imigração Sul-Sul, entre países em desenvolvimento, é muito significativa ${ }^{108}$ (WIHTOL DE WENDEN, s.d). No Brasil, o processo de anistia migratória de 2009 regularizou cerca de 43 mil imigrantes, dos quais 31.562 residentes em São Paulo, em sua maior parte sul-americanos (RIZEK; GEORGES; FREIRE DA SILVA, 2010). Somente os bolivianos chegaram a 16 mil, e entre paraguaios e peruanos há mais 5 mil anistiados ${ }^{109}$.

No mesmo ano desta Anistia migratória concedida pelo Brasil, 2009, também entraram em vigor as mais importantes medidas normativas regionais, os Acordos de Residência para Nacionais dos Estados Partes do Mercosul, Bolívia e Chile ${ }^{110}$ que exige somente a apresentação de um documento de identificação; certificado e declaração de ausência de antecedentes criminais e pagamento de taxas (art. 4). Além da redução do número de documentos exigidos, o imigrante tem a possibilidade de fazer o requerimento de residência tanto em uma representação consular do Brasil no seu país de origem, quanto diretamente à autoridade migratória brasileira quando já presente no território nacional. Neste último caso, o pedido de residência é possível independentemente da condição migratória do requerente quando entrou no país, e haverá isenção de multas ou outras sanções

\footnotetext{
${ }^{106}$ Argentina, Bolívia, Brasil, Chile, Colômbia, Equador, Guiana, Paraguai, Peru, Suriname, Uruguai, Venezuela. ${ }^{107}$ Ver p. 94.

${ }^{108}$ Sobre a migração boliviana para o Brasil, ver também: PRETURLAN, 2012.

${ }^{109}$ Dados obtidos junto à Delegacia de Migração da Polícia Federal em São Paulo.

${ }^{110}$ Promulgados pelos Decretos 6964 de 29 de setembro de 2009 e 6975 de 07 de outubro de 2009.
} 
administrativas. Os documentos administrativos não necessitam ser traduzidos em razão do “Acordo sobre Dispensa de Tradução de Documentos Administrativos para Efeitos de Imigração entre os Estados Partes do Mercosul, a República da Bolívia e a República do Chile"111 . O pedido feito com base no acordo do Mercosul dá direito a uma residência temporária de dois anos, quando então poderá ser transformada em permanente mediante a comprovação de possuir meios de subsistência lícitos (art. 5, d). Para os cidadãos argentinos as possibilidades de migrar para o Brasil são ainda mais facilitadas em razão de um acordo bilateral. O Acordo com a Argentina prevê a Concessão de Permanência a Detentores de Vistos Temporários ou a Turistas ${ }^{112}$.

Como se pode perceber, a legislação brasileira para os estrangeiros pouco avançou no reconhecimento de direitos para os imigrantes nos últimos trinta e quatro anos. Por outro lado, a normativa regional do Mercosul trouxe grandes conquistas nesse sentido. Todavia, muitos desafios ainda persistem. Ainda hoje, imigrantes dos países parte do Acordo de Residência do Mercosul permanecem sem documentos. Muitos, mesmo com documentos, continuam submetidos a exploração laboral e enfrentando dificuldades no acesso a diversos direitos no Brasil $^{113}$. Grande parte destes problemas diz respeito à execução dos serviços que garantem o acesso a diversos direitos, como é o caso dos serviços de saúde e educação, mas ainda persistem limitações jurídicas ${ }^{114}$. Um exemplo são as exigências para o reconhecimento de títulos e diplomas ${ }^{115}$, um tema muito trabalhado e discutido no âmbito do Mercosul (SERIKAWA, 2013; GONÇALVES, 2012) objeto de jurisprudência (MAZZUOLI, 2011), e uma questão central para o desenvolvimento da vida e do trabalho do imigrante mercosulino.

Em dezembro de 2010, a Decisão 64 do Conselho do Mercado Comum estabeleceu "um plano de ação para a conformação progressiva de um Estatuto de Cidadania do Mercosul”, o qual deverá ser implementado nos próximos dez anos. Seus objetivos gerais são: a) implementação de uma política de livre circulação de pessoas na região; b) igualdade de

\footnotetext{
${ }^{111}$ Acordo assinado em 15 de dezembro de 2000 e promulgado no Brasil pelo Decreto n. 5852 de 2006.

${ }^{112}$ Celebrado em Puerto Iguazú, em 30 de novembro de 2005 e promulgado no Brasil pelo Decreto 6736 de 12 de janeiro de 2009.

${ }^{113}$ A esse respeito vejam-se a CPI do Trabalho Escravo da Assembléia Legislativa do Estado criada pelo Ato do Presidente $\mathrm{n}^{\mathrm{o}} 7$ de 07/03/2014; o trabalho realizado pela ONG Reporter Brasil e os casos de grande repercussão de trabalho escravo nas cadeias produtivas das empresas Zara, M.Officer, Marisa, entre outras.

${ }^{114} \mathrm{~A}$ este respeito vejam-se as demandas e propostas apresentadas na $1^{\mathrm{a}}$ Conferência Municipal de Políticas para Migrantes, realizada pela Secretaria Municipal de Direitos Humanos e Cidadania de São Paulo através de sua Coordenação de Políticas para Migrantes (PREFEITURA MUNICIPAL DE SÃO PAULO, 2013).

${ }^{115}$ Tramita atualmente um projeto de lei que simplifica a revalidação de diplomas de cursos presenciais de graduação, mestrado e doutorado expedidos por instituições de educação superior estrangeiras de excelência reconhecida pelo poder público brasileiro, o PLS 399/2011. O Projeto já foi aprovado no Senado e enviado para análise e aprovação pela Câmara dos Deputados.
} 
direitos e liberdades civis, sociais, culturais e econômicas para os nacionais dos Estados Partes do Mercosul; c) igualdade de condições para acesso ao trabalho, saúde e educação. Para o alcance destes objetivos o plano de ação prevê a adoção de medidas em onze eixos: i) circulação de pessoas; ii) fronteiras; iii) identificação; iv) documentação e cooperação consular; v) trabalho e emprego; vi) previdência social; vii) educação; viii) transporte; ix) comunicações; $\mathrm{x}$ ) defesa do consumidor; xi) direitos políticos.

Pouco se avançou normativa e institucionalmente neste plano, conforme se verifica pelas atas das reuniões do Conselho Mercado Comum desde então. Em 2009, no entanto, o Mercosul passou a contar com o Instituto de Políticas Públicas em Direitos Humanos do Mercosul (IPPDH), cujas principais funções são "a cooperação técnica, a pesquisa, atividades de formação e o apoio à coordenação de políticas regionais em direitos humanos"116. No tema das migrações, o IPPDH elaborou solicitação de uma Opinião Consultiva à Corte Interamericana de Direitos Humanos sobre os direitos das crianças imigrantes apresentada em 06 de abril de $2011^{117}$, além de realizar um diagnóstico sobre a situação desta proteção nos países membros (IPPDH, 2012). Em 2010, foi criada a Unidade de Participação Social com a principal função de atuar como um canal de diálogo do Mercosul com a sociedade e os movimentos $^{118}$ e finalmente em 2011 foi aprovado o Plano Estratégico de Ação Social do Mercosul (PEAS) ${ }^{119}$. Em seu Eixo II "Garantir os direitos humanos, a assistência humanitária e a igualdade étnica, racial e de gênero", o PEAS estabelece a Diretriz 4: " Garantir que a livre circulação no MERCOSUL seja acompanhada do pleno gozo dos direitos humanos", cujo objetivo prioritário é: Articular e implementar políticas públicas voltadas a promover o respeito aos direitos humanos e a plena integração dos migrantes e proteção aos refugiados" (Decisão CMC 12/2011). Não obstante, a cidadania do Mercosul é um projeto pouco tangível, exceto pelos efeitos do Acordo de Residência o que pode tornar este projeto frágil diante das mudanças de conjuntura.

A título de comparação, note-se que o processo de construção da cidadania europeia não enfrentou apenas obstáculos operacionais. A disputa ideológica e estratégica foi central, eis que alguns a consideravam um conceito estratégico, e a defendiam como elemento importante do projeto de passagem de uma Comunidade econômica a uma União política, enquanto outros a rejeitavam como símbolo de um projeto federalista (MAGNETTE, 1999).

\footnotetext{
${ }^{116}$ Ver http://www.ippdh.mercosur.int/Acerca.

${ }^{117}$ A decisão de apresentar a solicitação de Opinião Consultiva foi tomada na Reunião de Altas Autoridades em Direitos Humanos e Chancelarias do MERCOSUR e Estados Associados (RAADH).

${ }^{118}$ Art. 4 Decisão CMC 65/2010.

${ }^{119}$ Decisão CMC 12/2011.
} 
A estruturação da cidadania sul-americana e os caminhos possíveis para o desenvolvimento do Acordo de Residência do Mercosul também implicam uma discussão conceitual sobre o próprio conceito de cidadania moderna.

$2.2 O$ discurso e a sua difícil efetivação: tensões na ordem politica, legal $e$ administrativa

Historicamente, a imigração para o Brasil está ligada à colonização do país. Iniciada em 1824 com a fundação da colônia de Nova Friburgo no Rio de Janeiro e continuada com a fundação de inúmeras colônias organizadas pelo governo ou por empresas privadas, sobretudo nos Estados da região Sul do Brasil. Como já se viu, este não foi um processo consensual e a questão da formação da nação frente às necessidade econômicas e geopolíticas esteve sempre presente nos debates a respeito dessa política de atração de imigrantes. Assim, ao longo deste período de políticas de subsídio e incentivo à imigração para o país, a normativa foi alterada com o estabelecimento de cotas, incentivo à naturalização, tentativas de evitar a concentração de imigrantes de mesma nacionalidade e garantir a sua assimilação etc. Para gerir este processo de colonização, alguns órgãos foram criados ao longo deste período. Em 1864, através do Decreto 3254, criou-se a Agência Oficial de Colonização responsável pelo transporte, desembarque, alojamento e distribuição dos imigrantes pelas colônias. Já no período republicano, em 1938, criou-se o Conselho de Imigração e Colonização pelo DecretoLei 406, conhecido como o $1^{\circ}$ Estatuto do Estrangeiro. Em 1954, a Lei 2163 de 5 de janeiro de 1954, atendendo a uma determinação da Constituição de $1946^{120}$ cria um único órgão para orientar, além da naturalização e colonização, a seleção, entrada, distribuição e fixação de imigrantes. É o Instituto Nacional de Imigração e Colonização (INIC).

A partir da década de 60, a colonização e, assim, a atração de imigrantes deixou de ser um objetivo do governo brasileiro e, nesse sentido, as instituições governamentais se transformaram. Em 1962 o Instituto Nacional de Imigração e Colonização (INIC) deixa de existir transferindo as atribuições de seleção de imigrantes para o MRE e as de recepção e encaminhamento primeiramente para a Superintendência de Política Agrária (SUPRA) ${ }^{121}$ e

\footnotetext{
${ }^{120}$ Art. 162, parágrafo único da Constituição de 1946.

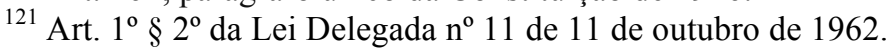


dois anos depois para o Ministério do Trabalho ${ }^{122}$. O Estatuto do Estrangeiro atual segue esta nova visão, elencando entre os seus objetivos a proteção do trabalhador nacional. A essa somam-se as preocupações com a segurança nacional, em consonância com o período ditatorial que o país atravessava.

Internacionalmente, as décadas de 50 e 60 foram o período de grande desenvolvimento dos programas de trabalho temporário (guest-work programs). As décadas seguintes marcaram a mudança desse direcionamento. A crise do petróleo em 1973 e as transformações no sistema econômico internacional somadas ao baixo índice de retorno dos trabalhadores temporários levaram ao encerramento destes e a uma crescente restrição e seletividade e à atual criminalização dos movimentos migratórios, com reforço do discurso tecnocrático da gestão dos fluxos mais recentemente.

No Brasil, já se viu, a lei é de 1980 e o quadro institucional vigente também remonta à este ano - com poucas alterações relativamente ao estabelecido na legislação anterior de 1969 (Decreto-Lei 941) — quando as competências sobre o tema foram divididas entre o MRE (concessão de vistos), o MTE (concessão de autorizações de trabalho e vinculação do CNIg) e o MJ (realização dos registro e decisão sobre de pedidos de alteração e autorizações de residência).

Houve muitas lutas durante as últimas décadas pelos direitos dos migrantes no Brasil (MILESI; UCHÔA, 2001; FÓRUM SOCIAL PELA INTEGRAÇÃO E DIREITOS HUMANOS DOS MIGRANTES NO BRASIL, 2012) e, ainda que a crescente presença de imigrantes no Brasil não fosse de conhecimento geral da população, as reivindicações resultaram em importantes instrumentos de garantia dos direitos dos imigrantes. Em 2005, o Brasil assinou um Acordo bilateral com a Bolívia para a regularização dos imigrantes. Em 2009, como já se viu, a lei 11.961, chamada Anistia migratória, entrou em vigor e, no mesmo ano, o Acordo de Residência do Mercosul, assinado em 2002, também passou a viger nos quatro países membros, mais Bolívia e Chile.

A partir do início dos anos 2000, com o aumento progressivo da chegada de imigrantes ao Brasil o tema começa a ganhar mais atenção. Primeiramente de organizações sociais de apoio à comunidade imigrante ${ }^{123}$, pouco a pouco das instâncias de governo envolvidas, mas sempre de forma muito setorial. Ainda hoje, o tema não é de domínio

\footnotetext{
${ }^{122}$ Art. $58 \S 2$ da Lei 4.505 de 30 de novembro de 1964 - Estatuto da Terra.

123 Através de um projeto da OIM com o Departamento de Estrangeiros do MJ, criou-se um Diretório das Instituições envolvidas com a temática migratória no Brasil - DITEM. O Projeto não disponibiliza o arquivo com todas as instituições, mas permite a busca pelo nome da instituição. Disponível em: http://www.brasil.iom.int/. Acesso em: 15 mai 2014.
} 
público. Apenas algumas questões pontuais chegam à mídia ${ }^{124}$ e acabam dominando a compreensão que se tem do todo. Por exemplo, a exploração de trabalhadores sul-americanos na indústria da confecção; o crescente fluxo de haitianos para o país desde a ocorrência do terremoto de 2010; além do tráfico de pessoas, temática de uma telenovela de grande repercussão nacional ${ }^{125}$.

Quando questionados sobre perceberem manifestações da sociedade a respeito das migrações e qual a importância destas na definição da políticas, foi apontado pelos entrvistados a dificuldade dos meios de comunicação em gerar aprofundamento sobre os temas, o que se reflete em certa espetacularização sobre questões pontuais como a exploração do trabalho imigrante, revelando também um desligamento histórico das contribuições e dos aportes da imigração para o países e uma despolitização sobre os fatores das migrações e outros que incidem sobre elas, como as discriminações de gênero e racial (Entrevistado 05). Foi destacado um "profundo senso comum e uma leitura marcadamente elitista e eurocêntrica na abordagem da grande imprensa". Além disso, "pouca voz ou quase nenhuma [é dada] à população migrante" o que qualificaria o debates, sem deixar de destacar que a definição dos conteúdos da política também passa por razões institucionais e políticas, de modo que a opinião pública é apenas uma das variáveis neste processo (Entrevistado 10).

Os entrevistados não proferiram discursos de caridade e humanitário ${ }^{126}$. Esses discursos muito presentes nas organizações sociais historicamente dedicadas ao tema, sobretudo ligadas à Igreja Católica, acabou influenciado o tratamento do tema, que tardou a despertar o interesse de outros setores sociais. Apesar de crescente e com desafios pontuais, as migrações também não eram um tema que mobilizasse setores econômicos ou políticos por mudanças, seja porque não lhes interessava, seja porque o modelo colocado não lhes era de todo desfavorável, ao menos até pouco tempo atrás.

Assim sendo, os próprios representantes governamentais e membros do Parlamento

\footnotetext{
${ }^{124}$ Existem diversos trabalhos que, recentemente, se dedicaram à compreensão do papel da mídia na produção de sentido e na construção de representações sobre as migrações em geral ou sobre fluxos migratórios específicos. Ver, por exemplo: COGO, 2001; ARAÚJO, 2011; ZANFORLIN et al.; 2014 ; DADALTO, s.d.; MOZINE et. al., 2012.

${ }^{125}$ Ver Novela Salve Jorge, de Glória Perez.

${ }^{126}$ Ver Instrução do Vaticano: "A Caridade de Cristo para com os Migrantes" e MILESI, 2004 sobre o tema. Sobre a caridade para com os migrantes, o texto finaliza: As migrações hodiernas constituem o maior movimento de pessoas, e quiçá de povos, de todos os tempos. Esses nos levam a encontrar homens e mulheres, nossos irmãos e irmãs, que por motivos econômicos, culturais, políticos ou religiosos abandonam, ou são obrigados a abandonar, as suas casas, para encontrar-se, na maioria das vezes, em campos de refugiados, em megalópoles sem alma, em favelas, onde o migrante partilha com freqüência a marginalização com o operário desempregado, o jovem desadaptado, a mulher abandonada. Por isso, o migrante está sedento de "gestos" que o façam sentir-se acolhido, reconhecido e valorizado como pessoa".
} 
brasileiro em diversas ocasiões também enfatizaram a questão do respeito aos direitos dos imigrantes, mas às vezes com certa confusão entre discursos humanitários e humanistas. No direito internacional, o Direito Humanitário precede a afirmação dos Direitos Humanos e é aquele aplicado durante os conflitos armados para minimizar os efeitos destas sobre os seres humanos. Origina-se no final do século XIX, início do XX, nas Conferências da Paz de Haia (1899 e 1907). Atualmente, são vigentes na matéria as Convenções de Genebra de 1949 e seus Protocolos de 1977. Os direitos humanos baseiam-se na idéia de direitos subjetivos comuns a todos os seres humanos, os quais devem ser opostos a todos, inclusive e sobretudo aos Estados nacionais. Enquanto o humanitário é uma atitude que minimiza consequências mais graves, o humanismo é fonte de empoderamento ${ }^{127}$.

Em 2009, o então presidente do Brasil, Lula, pronunciou-se sobre o tema ao encaminhar a Lei de Anistia Migratória ao Congresso Nacional enfatizando também o paralelo com as reivindicações e posturas do Brasil frente ao países mais desenvolvidos no que se refere aos seus próprios nacionais vivendo no Exterior.

(...) Essas novas leis significam que o Brasil se coloca cada vez mais à altura da realidade migratória contemporânea, das condições globais do desenvolvimento econômico e social, e do respeito fundamental aos direitos humanos. Elas são, também, resultado de um amplo debate nacional, com a participação de diferentes setores da sociedade e dos próprios imigrantes que tiveram, assim, a oportunidade de esclarecer os problemas que enfrentam e propor soluções.

É preciso destacar que essa anistia vem num momento muito especial, em que se aprofunda e se amplia o processo de integração da América do Sul. Ao longo de muitas décadas, o Brasil sempre acolheu europeus, asiáticos, árabes, judeus, africanos e, mais recentemente, temos recebido fortes correntes migratórias de nossos irmãos da América do Sul e da América Latina.

Somos, na verdade, uma nação formada por imigrantes. Uma nação que comprova na prática como as diferenças culturais podem contribuir para a construção de uma sociedade que busca sempre a harmonia e combate com rigor a discriminação e os preconceitos. Não só somos um povo misturado, como gostamos de ser um povo misturado. Daí vem grande parte de nossa identidade, de nossa força, de nossa alegria, de nossa criatividade e do nosso talento.

Não podemos esquecer que a própria Constituição brasileira, quando trata dos direitos e garantias fundamentais, estabelece que todos são iguais perante a lei, sejam brasileiros ou estrangeiros residentes. (...)

Defendemos que a migração irregular é uma questão humanitária e não pode ser confundida com a criminalidade. Adotamos sobre essa questão uma abordagem abrangente e equilibrada, levando em consideração os princípios da universalidade, interdependência e indivisibilidade dos direitos humanos.

Para milhares de brasileiros, viver em países como Estados Unidos, Japão, Itália, Espanha, Portugal, por exemplo, significa um sonho de progresso. Mas para muitos dos nossos vizinhos, o Brasil é visto como uma chance real de melhorar a sua vida. Aqui, esses estrangeiros têm direito à saúde pública e, seus fillhos, à educação gratuita, o que, infelizmente, não ocorre em muitos dos países que recebem 
imigrantes brasileiros.

Consideramos injustas as políticas migratórias adotadas recentemente em alguns países ricos, que têm como um dos pontos a repatriação dos imigrantes. Para nós, a repressão, a discriminação e a intolerância não lidam corretamente com a raiz do problema. Já disse várias vezes e repito: ninguém deixa sua terra natal porque quer, mas sim porque precisa ou porque acha que pode construir uma vida digna e melhor para si e para seus filhos em outro lugar. Falo isso por experiência própria. Foi isso que aconteceu com a minha família quando deixamos o sertão do Nordeste, em Pernambuco, rumo ao estado de São Paulo. Fomos buscar oportunidades, trabalho, estudo, melhores condições de vida. Por isso mesmo, julgo que os países mais ricos devem ter um enfoque solidário na questão da migração. Devem estabelecer parcerias que promovam o desenvolvimento das regiões e países onde se origina a migração, criando oportunidades, trabalho e melhores condições de vida.

(... )eu queria concluir dizendo para vocês que este é mais um exemplo que o Brasil quer dar ao mundo. Quando o primeiro ministro Gordon Brown esteve no Palácio da Alvorada, fazendo uma reunião bilateral, já começava a ter insinuações, em vários jornais brasileiros e estrangeiros, de que a perseguição aos imigrantes iria começar a acontecer (...)

E eu disse, naquela ocasião, que não deveria ser colocada culpa da crise provocada pelos homens de olhos azuis, em cima dos negros, e dos índios, e dos pobres do mundo. Porque no fundo, no fundo, a crise, se ela prejudica todo mundo, certamente ela prejudicará os mais pobres. E a gente está vendo, muitas vezes, o que acontece com brasileiros em países europeus.

(...)estarei na Itália, participando do G-8 (...) [e quero apresentar] um resumo do que nós estamos fazendo aqui, para que eu possa dizer a todos os presidentes dos países mais importantes do mundo, porque o Brasil toma posição, mostrando a contrariedade do Brasil com a política a ser adotada pelos países ricos.

(....)é bom que seja assim, é bom que a gente crie um mundo sem fronteiras, ou com fronteiras mais maleáveis, que permitam não apenas máquinas, produtos agrícolas, commodities atravessarem as fronteiras, mas que o ser humano seja olhado pelo seu lado bom e não se confunda o ser humano como exemplo de coisa ruim na travessia de uma fronteira (...) (SILVA, L. I. L, 2009, grifo nosso).

No ano anterior, 2008, todos os governos sul-americanos haviam criticado através de nota da União de Nações Sul-americanas, a aprovação pelo Parlamento Europeu da Diretiva de Retorno.

(...) los países miembros de UNASUR expresan su rechazo a la aprobación por parte de la Unión Europea (UE) de la llamada "Directiva de Retorno", y cualquier intento de criminalización de los migrantes que pueda implicar la aplicación de esta normativa, y subraya que los derechos humanos de que son titulares están garantizados por diversos instrumentos internacionales suscritos por los Estados de ambas regiones. En UNASUR estamos convencidos que la libre movilidad es un derecho inherente al ser humano, y en ese sentido el orden internacional debe contemplar la libre circulación de las personas. Asimismo, consideramos importante garantizar que las personas que están haciendo una contribución económica, social y cultural en otro país tengan un tratamiento digno y acceso a los elementos mínimos que les den seguridad y tranquilidad a si mismos y a sus familias (UNASUL, 2008, grifo nosso).

Vejam-se também alguns discursos oficiais relativos ao Acordo de regularização migratória Brasil - Bolívia de 2005, (prorrogado por três vezes, em 2006, 2007 e 2008). Na 
nota enviada pelo Brasil à Bolívia com a proposta de Acordo o favorecimento à inclusão dos migrantes é sublinhada, mas o controle sobre eles também:

O objetivo do Acordo é o de promover a integração socioeconômica dos nacionais dos dois países que se encontram em situação imigratória irregular no território de seus respectivos países, com base no interesse de fortalecer o relacionamento amigável existente. Tem presente a necessidade de outorgar um marco adequado às condições dos imigrantes dos dois países, possibilitando de forma efetiva sua inserção na sociedade do país receptor, e de criar um sistema para controle eficiente de imigrantes. (MRE, 2005, grifo nosso)

Nos pareceres das Comissões do Congresso sobre Projeto de Lei 16664/2007 que transformou-se na Lei 11961/2009, lei de Anistia migratória, os direitos humanos são invocados a partir de várias idéias, desde a suposta tradição de acolhimento do Brasil aos imigrantes; passando pela questão do desenvolvimento do país com a contribuição dos migrantes e chegando ao rechaço a políticas migratórias restritivas, fazendo contraponto às políticas dos países desenvolvidos:

Dos estrangeiros indocumentados no Brasil, os bolivianos são os que se encontram em pior situação. Em 2004, reportagem publicada na revista Época denunciava que a maioria dos bolivianos em situação irregular trabalha em oficinas de costura improvisadas, submetidos a uma jornada de até 16 horas por dia, em regime que se assemelha à semi-escravidão. Muitos desses migrantes chegam ao Brasil sem o passaporte, outros têm o documento apreendido pelos empregadores, que utilizam do expediente para manter os trabalhadores em situação irregular. É preciso por um ponto final nesse drama, que não se coaduna com a tradição de nosso País no que se refere ao acolhimento dos imigrantes estrangeiros, nem com os princípios constitucionais de respeito à dignidade da pessoa humana (art. $1^{\circ}$, inciso III, da CF) e de prevalência dos direitos humanos (art. $4^{\circ}$, inciso II, da CF).Importante ressaltar que a matéria regulada pela proposição sob exame possui precedentes. Conforme consta na justificação da iniciativa analisada, "em tempos recentes o Brasil tem concedido anistia aos estrangeiros. Deputado George Hilton - PP/MG (CÂMARA DOS DEPUTADOS, 2007, grifo nosso)

No particular, a possibilidade de efetivação do registro provisório dessas pessoas lhe trarão benefícios consideráveis, porquanto estarão autorizadas a exercer atividade remunerada, obter matrícula em estabelecimento de ensino e se locomover livremente pelo território nacional. Deputado Silvinho Peccioli - DEM/SP (CÂMARA DOS DEPUTADOS, 2008, grifo nosso).

(...) trata-se aqui de implementação de um instrumento normativo focado na integral proteção dos direitos humanos, dando vida aos dispositivos pétreos de nossa Constituição Federal, e, de certo, encontrando forte respaldo em toda sociedade brasileira, indignada com o recrudescimento de políticas migratórias, que se mostram cada vez mais restritivas e xenófobas, inclusive contra os nossos cidadãos que residem no exterior. Deputado Carlos Zarattini - PT/SP (CÂMARA DOS DEPUTADOS, 2009, grifo nosso) 
Nas discussões sobre a incorporação dos Acordos de Residência do Mercosul (Projeto de Decreto Legislativo no 943 de 2003) - em parecer no Senado, o acesso à regularização aparece como forma de combate à violações de direitos, além de enfatizar a importância para a integração da livre-residência dos nacionais dos Estados Partes:

\begin{abstract}
O Acordo em exame representa decisivo passo para a consolidação do Mercosul, uma vez que o Tratado de Assunção, em seu Artigo $1^{\circ}$, prevê a livre circulação de bens, serviços e fatores produtivos entre os quatros estados partes. Registre-se que o diploma internacional em apreço vem solucionar a situação migratória de nacionais dos Estados Partes na região, ao mesmo tempo em que facilita 0 combate ao tráfico de pessoas e ao trabalho ilegal dos imigrantes, por meio de medidas previstas para esse fim. Senador Pedro Simon - PMDB/RS. (SENADO FEDERAL, 2004, grifo nosso)
\end{abstract}

Ao analisar-se os textos dos acordos, os discursos dos parlamentares e dos governos durante a negociação, aprovação e ratificação destes acordos, percebe-se que o grande argumento a embasá-los são os direitos humanos, além do fortalecimento da integração regional, no caso do Mercosul, mas sem a ênfase no direito à mobilidade que se viu nos discursos anteriores da Unasul e do Presidente Lula. Nestes últimos, também, há, por vezes, a presença de argumentos contraditórios, como a referência a um "controle eficiente de imigrantes". Nota-se, finalmente, que são partidos de diversas vertentes ideológicas a se pronunciar neste sentido.

A referência aos direitos humanos no tratamento do tema e adoção de normas como a Anistia migratória e o Acordo de Residência do Mercosul, sugerem, para além dos discursos, uma divergência com a abordagem dos países desenvolvidos que atende predominantemente a interesses do mercado de trabalho ou da segurança. O quadro, no entanto, é mais complexo. Dois elementos embaralham a visão: a persistência do Estatuto do Estrangeiro como lei ordinária a reger a vida dos imigrantes e uma crescente tendência a enfatizar necessidade de atração de mão de obra qualificada para o mercado de trabalho brasileiro.

Um debate recorrente entre os estudiosos do tema das migrações versa sobre a existência ou não de uma política migratória no Brasil. Entre os representantes governamentais, apenas um afirmou considerar que não existe uma política para o tema, fazendo referência à Política Nacional de Imigração e Proteção a(o) Trabalhador(a) Migrante $^{128 "}$ aprovada em 12 de maio de 2010 pelo CNIg e posteriormente submetida à 
Consulta Pública, a qual deveria ter sido transformada em Decreto, mas não o foi. $\mathrm{O}$ Entrevistado 01, do governo, considera que não exista uma política mais articulada com visão de longo prazo, apenas iniciativas tópicas e localiza a competência para a mesma no CNIg. O Entrevistado 05, também representante do governo, considera que a discussão sobre este ponto é uma discussão sobre o rótulo, porque sempre que o Estado age, o faz "mediante decisões de política pública" e defende, assim, "que não se invisibilizem as práticas do Estado brasileiro durante os séculos XIX e XX como parte de uma política coerente do Estado". Acredita "que o discurso da invisibilização dessa política serviu para que ela não fosse acompanhada, monitorada, colocada em discussão". Identifica alguns instrumentos desta política: as anistias periódicas, o tipo de relação da Polícia Federal no atendimento, e a baixa ou nenhuma participação social. Finalmente, o Entrevistado 03, do governo, também faz referência à Política aprovada pelo CNIg em 2010 e considera que, apesar de não aprovada, está implementada, pois é base para as decisões que são tomadas ali, citando por exemplo as Resoluções Normativas sobre o visto humanitário para os haitianos e a Resolução Normativa $n^{\circ} 93$ que "disciplina a concessão de visto permanente ou permanência no Brasil a estrangeiro considerado vítima do tráfico de pessoas" permitindo a regularização das pessoas vítimas desse crime que até então, em muitos casos, eram deportadas.

Chama atenção, nesse caso, a fragilidade do alcance do entendimento da política, pois em que pese que as referidas resoluções tenham baseado-se no texto desta Política protetiva dos direitos dos migrantes, o peso da legislação, da institucionalidade e da ausência de políticas públicas de promoção destes direitos se faz sentir amplamente, na contramão da referida Política. O próprio PL 5655/2009 ${ }^{129}$, apesar de enxertar a expressão direitos humanos no seu art. $2^{\mathrm{o}^{130}}$, mantém como objetivos perseguidos pela lei a defesa do interesse nacional e a preferência à mão de obra especializada (art. $4^{\circ}$ ). Os artigos introdutórios não esclarecem como estes objetivos potencialmente contraditórios serão balanceados, mas o restante do projeto é bastante esclarecedor. De forma geral, a ideia da segurança nacional permanece no projeto e com ela, toda a burocracia que decorre do controle permanente dos estrangeiros ${ }^{131}$ :

pelo Conselho Nacional de Imigração (CNIg) do Ministério do Trabalho e Emprego e pela Organização Internacional do Trabalho (OIT), com a participação de órgãos de governo, sindicatos patronais e de trabalhadores, representantes de associações de apoio a migrantes e acadêmicos. Ver: PÓVOA NETO; SPRANDEL, 2009.

${ }^{129}$ Sobre o PL 5655/2009, ver p. 89-90.

130 Art. 2º A aplicação desta Lei deverá nortear-se pela política nacional de migração, garantia dos direitos humanos, interesses nacionais, sócio-econômicos e culturais, preservação das instituições democráticas e fortalecimento das relações internacionais.

${ }^{131}$ Vejam-se os arts. 28, 29, 30, 78, 79 do PL 5655/09. 
o paradigma nacionalista e seletivo permanece. O favorecimento da recepção de mão de obra qualificada e da centralidade das autorizações de trabalho para obtenção de status migratório regular também se mantêm, demonstrando um forte desequilíbrio entre os princípios supracitados: o do interesse nacional - de segurança e/ou proteção do mercado de trabalho nacional - e o da garantia dos direitos humanos dos migrantes.

Sobre a relação entre a garantia de direitos e a proteção do trabalhador nacional, o Entrevistado 03 esclarece que esta se refere à vedação à atração estimulada de trabalhadores para fazer frente a pressões salariais, por exemplo. A ideia é que as migrações não sejam um instrumento de precarização do mercado de trabalho. Afirma ainda que os que estão trabalhando, que conseguiram se estabelecer mesmo de forma indocumentada devem ter a possibilidade de se regularizar, não através de regularizações extraordinárias, mas através de canais permanentes: "isso não é desproteger o trabalhador brasileiro, ao contrário, é aplicar o princípio da igualdade".

A sociedade civil já há alguns anos denuncia os problemas do Estatuto do Estrangeiro e do tratamento dos imigrantes em geral ${ }^{132}$, mas no texto do PL de 2009 permanece a restrição de direitos políticos ${ }^{133}$, para além do direito ao voto que é questão constitucional ${ }^{134}$. Há ainda questões que estão reguladas de forma mais restrita, como a naturalização que teve o seu prazo aumentado. É de quatro anos no Estatuto atual (art. 112) e passa a dez no PL 5655/2009 (art. 87, III). Além disso, a vedação de polipatridia, mais comumente conhecida como dupla nacionalidade, estabelecida pela Constituição em seu art. $13 \S 4^{\circ}$, completam o quadro de uma regulação da nacionalidade que não atende garante respeito aos direitos dos imigrantes.

Mais recentemente, o quadro normativo e institucional da política migratória brasileira passaram a ser objetos de crítica por dificultarem a entrada de imigrantes qualificados, em falta no mercado de trabalho brasileiro. A Secretaria de Assuntos Estratégicos (SAE) declarou publicamente que o Brasil pode receber até 6 milhões destes trabalhadores nos próximos 20 anos (MELLO; CARNEIRO, 2012a). Por solicitação da Presidência da República no início de 2012 a SAE começou a trabalhar em um diagnóstico a respeito do tema (OTAVIO; GUILAYN, 2012). Este diagnóstico não foi publicado, e em fevereiro de 2013 foi criada uma

\footnotetext{
${ }^{132}$ Ver: MILESI; UCHOA, 2001.

133 Art. $8^{\circ}$ PL 5655/09: O estrangeiro admitido no território nacional não pode exercer atividade políticopartidária, sendo-lhe vedado organizar, criar ou manter associação ou quaisquer entidades de caráter político, salvo o português com o gozo dos direitos políticos no Brasil, conforme previsto no Tratado de Amizade, Cooperação e Consulta.

${ }^{134}$ Nesse particular, praticamente todos os vizinhos sul-americanos já avançaram em maior ou menor medida na garantia do direito ao voto para os imigrantes, com diferenças no que se refere ao tempo de residência e ao nível político-administrativo das eleições em que lhes é permitido participar.
} 
Comissão Especial junto ao CNIg para discutir mudanças nas regras de vistos de trabalho para migrantes de alta qualificação (RESENDE, 2013).

Em estudo encomendado ao Instituto BRAiN (Brasil Investimentos \& Negócios) pela SAE, apontou-se que um visto de trabalho demora quase 2 meses para ser emitido e é exigida a apresentação, em média, de 19 documentos. O estudo é comparativo e aponta que outros países tem exigências menores e prazos mais céleres para este processo (MELLO; CARNEIRO, 2012b). Finalmente, a solução encontrada para avançar no tema foram as Resoluções Normativas (RNs) do CNIg. Até o momento foram promovidas as seguintes mudanças, segundo publicado no site da SAE:

\begin{abstract}
a) Permissão de trabalho para cônjuge de estrangeiro com contrato de trabalho (RN 99); b) Visto técnico de três meses, um dos mais utilizados no Brasil, emitido diretamente pelos consulados, sem análise prévia do MTE, adiantando em até um mês o processo (RN 100); c) Summer jobs: permissão de trabalho por até 90 dias para pós-graduandos que queiram trabalhar no Brasil durante as férias letivas (RN 103); d) Prazo de 60 dias para empresa emitir visto e apresentar documentos consularizados e com tradução juramentada (RN 104); e) Possibilidade para estrangeiro mudar de local de trabalho, cargo ou empresa (no mesmo grupo econômico) sem autorização do MJ, bastando informar a mudança (RN 104); f) Prazo de até 30 dias da entrada do estrangeiro no Brasil para o contrato de trabalho começar a vigorar. Nesse período, ele poderá obter o Registro Nacional de Estrangeiros e a Carteira de Trabalho, o que evitará a necessidade de folha de pagamento retroativa (RN 104) (SAE, s.d).
\end{abstract}

Isto não significa que se tenha implementado um programa de atração de mão de obra especializada. Trata-se apenas do destravamento da burocracia, mas direcionado especificamente aos trabalhadores especializados.

Nas entrevistas realizadas com os representantes governamentais, questionados sobre a força com que o tema da migração qualificada irrompeu no cenário político e sobre o seu lugar na política migratória, todos afirmaram, com maior ou menor convicção, que a atração de imigrantes qualificados é apenas um dos elementos de uma política migratória que deve ser maior, baseada nos direitos humanos. Em especial o entrevistado 10 afirmou haver ponderado com os representantes da $\mathrm{SAE}$, com relação às propostas de alteração que eles apresentariam "nós teríamos que universalizar estes critérios e esses mecanismos, pois que não seria admissível que nós tivéssemos dentro do ordenamento jurídico procedimentos e exigências desniveladas entre os cidadãos, ainda mais por razão de ordem econômica ou educacional porque isso implicaria em discriminação". O entrevistado 05 corrobora este entendimento ao afirmar que seu órgão trabalha com "a construção isonômica de direitos, de eliminar barreiras e assimetrias. (...) Então iniciativas para desburocratizar, para gerar facilitações no acesso a 
vistos (...) são desejáveis desde que elas possam ser universalizáveis (...)". Finalmente, o entrevistado 03 afirmou que em seu órgão de atuação, "sempre trabalhou-se com uma perspectiva diferente. As migrações são um fenômeno natural do mundo e crescem com a facilidade do movimento de pessoas, acesso à informação, globalização (...). A perspectiva sempre foi construir um marco de políticas e normas para inserir o Brasil em um cenário onde haverá mais mobilidade de pessoas de todos os tipos: qualificadas, não qualificadas (...), focado em direitos. Eu acredito que o país vai melhor ou pior em relação às migrações quanto mais possibilidade de integração no país [têm os imigrantes]".

No entanto, o entrevistado 10 ressalta que não considera "de toda forma ilegítimo que nós constituamos mecanismos de busca de profissionais qualificados. Não vejo nenhum problema nisso se isso estiver integrado a uma visão de nação que ajude a suprir dificuldades estruturais em nosso país, acelere o desenvolvimento (...)". Até o momento, o único programa de atração de mão de obra que de fato efetivou-se foi o chamado Mais Médicos, um dos principais programas da atual gestão do governo federal. Criado pela Medida Provisória ${ }^{\circ}$ 621 de 08 de julho de 2013, posteriormente convertida na Lei 12.871 de 22 de outubro de 2013 e Regulamentado pelo Decreto 8126 da mesma data, o Programa é mais amplo e envolve a reestruturação da formação de médicos e ampliação de vagas nas faculdades de medicina do país. Mas a ação que mais atraiu a atenção da opinião pública foi a vinda de médicos estrangeiros para atuar em regiões onde não há oferta suficiente de profissionais. Em especial, a vinda de médicos cubanos foi objeto de críticas, por vezes racistas ou xenófobas ${ }^{135}$ (BRUM, 2013). Cuba é um dos países com maior oferta destes profissionais - 6,72 por mil habitantes enquanto o Brasil possui 1,89 por mil —, podendo atender a demanda brasileira sem que se prejudique a população local (MINISTÉRIO DA SAÚDE, 2013). O Programa Mais Médicos não atende a demandas de empresas, também não promove uma abertura ampla, mas visa atender a uma demanda de saúde pública ${ }^{136}$.

De fato, não parece que a convivência entre uma política migratória baseada em direitos e a atração de mão de obra em setores específicos seja impossível, desde que exista uma lei que garanta estes direitos de forma geral e que abra canais de migração regular, reconhecendo a migração como um fato social transnacional e respeitando as decisões dos imigrantes. Os programas de atração de mão de obra qualificada devem, neste caso, consistir

\footnotetext{
${ }^{135}$ Ver nota 85.

${ }^{136}$ Foram apresentadas duas Ações Diretas de Inconatitucionalidade (ADI), no 5035 pela Associação Médica Brasileira e $n^{\circ} 5037$ pela Confederação Nacional dos Trabalhadores Liberais Universitários Regulamentados, ainda sem julgamento. Houve Audiência Pública no STF sobre o tema nos dias 25 e 26 de novembro de 2013.
} 
em incentivos, institucionais, econômicos, campanhas publicitárias a respeito das oportunidades estabelecidos unilateralmente ou mediante negociações com países interessados, sempre considerando os debates a respeito do brain drain ${ }^{137}$.

$\mathrm{O}$ atendimento dos imigrantes realizado pela Polícia Federal cujos agentes possuem formação securitária, citado por um dos entrevistados como um dos instrumentos da política migratória brasileira, também é alvo de severas críticas. As reivindicações de criação de um órgão civil que pudesse se responsabilizar pela matéria não estão contempladas no PL $5655 / 2009$ de iniciativa do Executivo ${ }^{138}$. A securitização das fronteiras também é reconhecida pelos entrevistados. O Entrevistado 10 afirma que isto está claro no ENAFRON (Estratégia Nacional de Segurança Pública nas Fronteiras) e que a recepção de grande eventos no país traz consigo a agenda do terrorismo, relatando que inclusive no Mercosul, onde os temas são objeto de diferentes grupos de trabalho, o Foro Especializado Migratório (FEM) foi procurado pelo Foro Especializado de Terrorismo e Controle para que este tema fosse internalizado na pauta migratória. O Entrevistado 01 reconhece que há uma tensão entre a necessidade de controle e as violações de direitos humanos na fronteira, sem deixar de apontar as carências de recursos para realizar este controle. Finalmente, o Entrevistado 05 afirma que durante grande parte do século XX a visão da fronteira como "domínio e [instrumento para] contenção de ameaças" foi cultivada, em especial "durante o período da ditadura brasileira (...). Mas nós precisamos avançar para uma perspectiva de integração, da fronteira a ser tratada não como margem de um sistema, mas como ponte entre sistemas sociais ricos. (...) Nós precisamos autonomizar a política migratória da política de segurança nas fronteiras (....) a proteção dos fluxos humanos não pode estar submetida a exigências puramente securitárias, policiais".

A quesstão da distribuição de competências também é central nos debates sobre a política migratória no Brasil. Atualmente não há um órgão ou Ministério que centralize a política, ou ainda um mandato claro a respeito da implementação de políticas públicas que atendam as especificidades dos migrantes. Questionados a respeito de o Brasil implementar políticas de integração social para os migrantes, o Entrevistado 01 respondeu afirmativamente, mas destacou que isso se choca com o que chamou de "nossa não-política". Sublinhou ainda a ausência de dados sobre esta população, o que dificulta a implementação de políticas públicas. O Entrevistado 03 acredita que "a falta de uma política de integração

\footnotetext{
${ }^{137}$ Refere-se ao impacto da migração qualificada, como uma perda de recursos dos países de origem e assim, causa e consequência do subdesenvolvimento (PÉCOUD, LEVATINO, 2012).

${ }^{138} \mathrm{O}$ Anteprojeto de Lei de Migração aberto à contribuições até o dia 23 mai 2014 prevê a criação de uma Autoridade Nacional Migratória.
} 
significa uma política de exclusão (...). O resultado disso são estes conflitos sociais que aconteceram por lá [Europa], nós não queremos isso aqui. Temos que trabalhar para ter uma sociedade adaptada a isso, a pessoas de várias nacionalidades, sem que cada uma perca a sua nacionalidade". Finalmente, o Entrevistado 05 não detecta "opiniões contrárias ao aperfeiçoamento da integração, mas que diferenças ocultas não estão expressas (...) nós precisamos visibilizar essas diferenças e perceber quais são as bases que legitimam a eventual inexistência de políticas de integração". Os entrevistados não especificaram de forma mais concreta o conteúdo dessas políticas, mas parece claro que o entendimento não é assimilacionista, mas garantidor de inclusão e diversidade. O Entrevistado 03 arriscou algumas ideias, mencionando classe extras de português para as crianças, cursos de qualificação profissional específicos e cursos de idioma.

Em todos estes depoimentos, fica claro o déficit que acomete toda e qualquer medida governamental no tema das migrações, em razão da ausência de um marco legal adequado para o tratamento do tema dentro do paradigma anunciado dos direitos humanos. Há, nesse sentido, entre os entrevistados uma convergência a respeito da necessidade de substituição da legislação vigente, e da insuficiência e inadequação do texto em tramitação. Nas palavras do Entrevistado 05 "[a política] vai se mostrar cada vez mais desligada das demandas da realidade social brasileira presentes".

O CNIg, órgão ligado ao MTE, com participação de todos os ministérios interessados no tema das migrações, além de representantes dos empregadores e dos trabalhadores e responsável pela elaboração dos objetivos da política migratória ${ }^{139}$ promoveu diversas atualizações na legislação. No entanto, as resoluções normativas adotadas por este Conselho não podem mudar a lei e o seu paradigma e nem mesmo excluir disposições flagrantemente em conflito com a Constituição de 1988 e com os diversos tratados de direitos humanos dos quais o Brasil é signatário.

A atualização da legislação promovida pelo CNIg é um dado que apareceu em todas as entrevistas. Perguntados sobre os motivos da não aprovação de uma nova legislação migratória para o Brasil quase todos os entrevistados apontaram a atuação paliativa do Conselho, além da falta de interesse da parte do governo e dos parlamentares em dar prioridade ao assunto. Em que pesem as importantes Resoluções do CNIg para a garantia de direitos humanos em situações pontuais, como a reunião familiar (RN 36/1999), inclusive com base na União estável de pessoas do mesmo sexo (RN 77/2008), sobre situações

\footnotetext{
${ }^{139}$ art. 144, II do Decreto 86715/81 que regulamenta o Estatuto do Estrangeiro.
} 
especiais e casos omissos (RN 27/1998), a concessão de visto permanente para vítimas de tráfico de pessoas (RN 93/2010) entre outras, a maior parte delas refere-se a regulamentações relativas à entrada de profissionais específicos, estudantes ou investidores ${ }^{140}$. Os membros do CNIg entrevistados, em especial a representação das Confederações Patronais salientaram reiteradamente a importância da atuação do CNIg para conseguirem atender as demandas de seus setores por mão de obra especializada.

Também é fato que o CNIg e o MTE tem se empenhado em tornar mais ágeis e menos burocráticos os processos de tramitação de autorizações de trabalho, informatizando procedimentos e diminuindo prazos. É um dado interessante que os imigrantes não tenham reclamações ou demandas sobre as situações trabalhadas pelo $\mathrm{CNIg}^{141}$, à exceção da resolução sobre o visto humanitário dos haitianos. Isto revela ao menos duas questões: que o trabalho que o CNIg faz é satisfatório no que realiza, mas que a amplitude de sua atuação é bastante restrita, tendo em vista que as críticas à política brasileira para as migrações em geral são muitas. O enfrentamento de muitas dessas questões dependem de um novo marco legal e possivelmente institucional sobre o tema, ainda que apenas um marco legal seja insuficiente. A luta dos movimentos de migrantes é o que pode mover a sua adoção e a sua efetivação.

O caso da imigração haitiana é bastante emblemático no sentido de verificar as limitações da atual configuração institucional e normativa no tema. Primeiramente, porque a decisão a respeito da adoção da resolução que concede o visto humanitário não foi tomada pelo CNIg. A proposta partiu do Executivo e foi aprovada pelo CNIg (ÉBOLI, 2012). Além disso, diante da crise humanitária (CONECTAS, 2013) que se instalou no abrigo que recebia os haitianos recém-chegados ao Acre, ficou clara a insuficiência de resoluções normativas para lidar com situações em que são necessárias medidas governamentais estruturadas e inseridas em uma política para as migrações clara no Estado brasileiro.

A medida pontual, tomada no início pelo CONARE, de encaminhar os pedidos de refúgio apresentados pelos haitianos ao $\mathrm{CNIg}$ não foi suficiente para lidar com este movimento migratório e uma nova concentração de imigrantes haitianos em cidades pequenas e sem grande infraestrutura na fronteira norte exigiu novas medidas. Foi então que reuniu-se o primeiro escalão do governo, e destes entendimentos conseguiu-se a edição pelo CNIg da Resolução Normativa específica para o caso dos imigrantes haitianos (MILESI, 2012). Tratase da RN 97/2012, complementada pela RN 102/2013 que prorrogou a sua vigência até

\footnotetext{
${ }^{140}$ Ver lista de todas as Resoluções Normativas na página do CNIg, Portal do MTE.

${ }^{141}$ Ver propostas da $1^{\text {a }}$ Conferência Municipal de Migrações (PREFEITURA MUNICIPAL DE SÃO PAULO, 2013).
} 
outubro de 2014, eliminou as quotas e permitiu que o visto fosse concedido em qualquer representação do MRE.

Apesar do estabelecimento de quotas, agora já derrubadas, o discurso que embasou a Resolução era, além de humanitário, o da garantia dos direitos humanos dos imigrantes e da sua proteção contra os perigos da imigração irregular e do recurso aos serviços de coyotes. Esta medida também foi insuficiente. $\mathrm{O}$ abrigo de Brasiléia-AC chegou a uma situação calamitosa e a situação foi levada ao Conselho de Direitos Humanos da ONU (CONECTAS; MESA NACIONAL PARA LAS MIGRACIONES Y REFUGIO EN REPÚBLICA DOMINICANA, 2014) em razão da ausência de uma política que garantisse condições dignas aos imigrantes. A medida mais recente foi o fechamento do abrigo em Brasiléia e abertura de dois outros, um em Rio Branco, onde os imigrantes aguardarão a documentação, e outro em São Paulo (SANT'ANNA, 2014; ANDRADE, 2014).

Mais recentemente, uma outra situação também é emblemática da necessidade de uma política que vá além de resoluções. Em setembro de 2013, diante da crescente demanda entrada no Brasil dos sírios em fuga do conflito que acomete o país, o CONARE editou uma RN 17 de 20 de setembro de 2013 que visa a facilitar para estas pessoas a obtenção de visto para que busquem refúgio no Brasil. A Resolução não cria um novo visto, o que nem mesmo é competência do Comitê, mas determina que dentro do contexto de conflito que aquele país vive, deve ser concedido aos sírios o visto mais adequado previsto na Lei 6815/1980 para que consigam chegar ao território brasileiro.

Além da edição desta Resolução, nenhuma outra medida foi tomada pelo governo brasileiro para recepcioná-los; não houve apoio ao seu acolhimento, nem preparação nos aeroportos ou reforço na burocracia migratória para processar as suas solicitações. Assim sendo, não lhes é possível receber o protocolo de solicitação de refúgio em sua chegada. Eles recebem apenas um agendamento para entrevista na Polícia Federal, que no início de 2014 chegava a demorar sete meses (FARIAS; CIOFFI, 2014). Após o vencimento de seus vistos, em geral de turismo, passam a estar em situação migratória irregular. Durante este período, não conseguem fazer suas carteiras de trabalho, nem alugar um imóvel ou solicitar um CPF, nem mesmo habilitar um número de telefone celular. Dependem da solidariedade, em geral da comunidade árabe estabelecida há mais tempo no país, ou dos serviços públicos que são insuficientes para atendê-los ou que por vezes lhes são negados em razão da mesma ausência de documentação (MANTOVANI, 2014). Esses casos ilustram as consequências da aplicação de uma política de migração restrita à resoluções normativas.

A respeito, então, do conteúdo de uma nova legislação sobre o tema, o Entrevistado 10 
afirma que esta deve contemplar primeiramente "um capítulo de abertura em torno dos direitos dos migrantes. Em segundo lugar, suprir uma lacuna que estabeleça um mecanismo de coordenação e governança da política migratória no país que, ao [seu] juízo é um dos grandes déficits existentes e que acaba gerando esse estado de inação. (...) E em terceiro lugar, o foco está na tomada de medidas de racionalização e simplificação para que o modelo se torne menos burocrático e reflita um melhor trato no âmbito da democracia com a questão da presença do migrante (...)". O Entrevistado 03 entende que a nova política deve contemplar o respeito dos direitos fundamentais dos migrantes, o entendimento de que a migração irregular não é crime e que a integração dos migrantes é fundamental. O Entrevistado 01 também aponta a necessidade de desburocratização da emissão e regulação do sistema de vistos e o Entrevistado 05 suscita as questões da importância da abertura à participação social, da garantia de direitos, sumprimindo-se as barreiras regulamentares, infra-legais e administrativas a estes, além da "criação de mecanismos de financiamento de ações políticas e o esclarecimento de responsabilidades, do papel, da competência mais clara sobre que estruturas conduzem as ações de promoção de direitos dos imigrantes no país". Pugna também pelo "estabelecimento de planos periódicos em que se avalie e se aperfeiçoem as ações do Estado para a população.

A já citada distinção entre políticas de migração e políticas de controle, apesar da impossibilidade separá-las, ou seja, apesar do reconhecimento de que estas operam sempre conjuntamente nos facilita a análise de que uma política de migração sem uma base de direitos sobre a qual esteja construída sempre estará tratando de, no mínimo, seletividade. Assim, mesmo as políticas de controle: biometria e scanners em aeroportos e fronteiras, bancos de dados compartilhados, etc., são políticas que permitem a migração daqueles que não são alvo do controle. Da mesma forma, as políticas de migração (por exemplo, de atração de determinado segmento de trabalhadores) são políticas que impedem a entrada de outros que não fazem parte deste segmento (SQUIRE, 2011). Apenas uma política baseada em direitos humanos é capaz de ser uma política de mobilidade.

Sobre o tema da divisão de competências e estrutura institucional dos órgãos responsáveis pelo tema das migrações, o Entrevistado 10, questionado a respeito do mecanismo de coordenação e governança da política migratória que citou em sua fala, em relação ao CNIg precisou:

(...) é fundamental a permanência da existência de órgão colegiado para definir periodicamente as estratégias, a formular a priori a grande política, mas depois ter a responsabilidade de ir implementando os planos (...), aqui é uma opinião pessoal, particularmente eu sou favorável à criação de uma unidade administrativa que 
centralize as funções difusas que estão hoje em distintos ministérios (....) que tenha algum nível de funções executivas (...). Esse é o tipo de proposta que envolve reforma institucional, então ela só pode ser pensada concretamente. (...) Eu não saberia dizer, por exemplo, se haverá adesão dos outros ministérios a essa proposição.

Os problemas derivados da inexistência desta coordenação de competências e de um órgão com funções executivas são numerosos. Desde a falta de dados, ausência de transparência e canais de comunicação coordenados e adequados, à insuficiência e inadequação do aparato burocrático, a inexistência de políticas de acolhimento e integração, e de uma diretriz de trabalho conjunto com os órgãos descentralizados em Estados e municípios que tratam do tema etc. O CNIg, responsável pela política migratória, em que pese seus esforços nas últimas décadas não é um órgão capaz de responder a estes desafios. No curso dos anos, demonstrou ter pouca influência sobre os outros ministérios, de modo que a sua capacidade de implementação de políticas públicas se viu limitada. Soma-se a isso o fato de que a permanência dos trâmites burocráticos nas mãos da Polícia Federal gera inúmeros problemas: atraso, ineficiência e o viés securitário no tratamento dos migrantes, dos quais os demais ministérios se veem reféns, em razão da ausência de um corpo de funcionários civil próprio. Finalmente, um órgão como CNIg é importante para o permanente monitoramento das políticas migratórias relativas ao trabalho, atuando naquela faixa acima das garantias de direitos, que deverão estar previstas em lei.

O Poder Público atua, neste quadro, reativamente aos problemas que surgem em virtude dessa conjuntura que reúne ausência de políticas e aumento de fluxos. A continuar, essa política contribuirá certamente para que a migração passe a ser vista como um problema, dando ensejo para que discursos restritivos e episódios de xenofobia floresçam ${ }^{142}$.

Dito de outro modo, a ausência de política desloca o foco dos problemas. De certa forma, a política parcial, emergencial e reativa do governo contribui para a vulnerabilização dos migrantes. No caso da imigração sul-americana, a questão que durante anos tomou conta do debate foi a do trabalho escravo. Os imigrantes eram apresentados como vítimas, e o estigma da imigração como um problema foi fortalececido. As decisões desses indivíduos de migrar e/ou de permanecer no país eram silenciadas em nome da sua proteção enquanto vítimas. Em todos os casos, no entanto, o problema de fundo é a exploração do trabalho. $\mathrm{O}$ que o Brasil precisa garantir é a fiscalização das condições de trabalho e das cadeias

\footnotetext{
${ }^{142}$ Por exemplo, veja-se estes fatos ocorridos em Cascavel: HAITIANOS..., 2014a e HAITIANOS..., 2014 b.
} 
produtivas, além de condições jurídicas e sociais para que estas pessoas não precisem se submeter a esta exploração. O trabalho de fiscalização e punição das violações realizado pelos Ministério do Trabalho e Ministério Público do Trabalho é notável e imprescindível, mas incapaz de sozinho transformar a realidade de exploração do trabalho migrante ${ }^{143}$.

Como já dito, a migração não é uma experiência emancipatória em si, mas é um espaço, uma oportunidade de construção de liberdade. Logo, uma política migratória baseada nos direitos humanos deve proporcionar os meios para que esse objetivo seja atingido. Certamente não é buscando impedir as migrações sob o pretexto de não alimentar a exploração que se terá esta política migratória humanista proclamada pelo Brasil. Como ocorre nos países do Norte, a demanda por mão de obra barata e explorável permanecerá de modo que as pessoas continuarão entrando no país, ainda que com maiores dificuldades, submetidas a maiores violações ou se direcionarão a outros destinos de mais fácil entrada, mas com a mesma perspectiva de exploração.

Nesse contexto de problemas e promessas, o elemento mais interessante quando se fala de uma política migratória baseada em direitos humanos é o já citado Acordo de Residência do Mercosul. De certa forma, ele supera parcialmente a necessária vinculação da migração com uma justificativa considerada legítima como ter um contrato de trabalho ou um vínculo familiar que lhes permita obter documentos. Parcialmente, porque após dois anos de residência, o migrante precisa ainda comprovar que se dispõe meios de vida lícitos que permitam a sua subsistência e de seu grupo familiar de convívio (art. 5, 1, d). De toda forma, o acordo representa uma experiência coerente com o paradigma da mobilidade, reconhecendo que esta faz parte cada vez mais das dinâmicas sociais transnacionais da contemporaneidade e respeitando as decisões dos migrantes .

O Acordo de Residência foi aprovado em 2002 pela Reunião de Ministros de Interior do Mercosul. Em 2004, e também fruto do processo de construção do Acordo, foi criado o Foro Especializado Migratório (FEM). Este foi o período em que a Argentina estava em plena discussão de sua nova legislação migratória, adotada em 2005, paradigmática na garantia dos direitos humanos dos migrantes (ALFONSO, 2012). À proposta do Brasil de uma espécie de Anistia migratória para os nacionais do bloco por 6 meses, a Argentina respondeu com uma contraproposta de "Anistia permanente" ou "Canal de Regularização Permanente", o que finalmente foi aceito pelo Brasil, pelo Uruguai e Paraguai, este último com certa resistência

${ }^{143}$ Ver: MTE, s.d. 
(ALFONSO, 2012) ${ }^{144}$, o que certamente também demonstra a sua precariedade, ainda muito dependente de decisões nacionais dos países membros, como de resto, todo o funcionamento do Mercosul

O Acordo de Residência, no entanto, é apenas uma pista para a construção de uma política migratória não-excludente. Para tanto, é importante não cometer o mesmo erro da Europa que ao formatar a sua cidadania regional apenas alargou o campo de aplicação do critério nacional. Os elementos que poderiam fundamentar uma nova narrativa política a respeito das migrações, construída na América do Sul são, por exemplo, a realidade de emigração muito presente na região (SAYAD, 1998) e a organização das comunidades de emigrantes para a reivindicação de direitos; a rejeição da lógica econômica pura do neoliberalismo imposta pelo Norte e desastrosamente experimentada nos anos 80, mostrando que a construção de alternativas era necessária para a sobrevivência (MUNCK, 2010); somados ao histórico de imigração presente na formação de forma mais ou menos marcante em todos os países e a luta por direitos e por oportunidades efetivamente iguais de outras comunidades marginalizadas historicamente, apesar de nacionais, como negros e índios. Finalmente, a defesa dos direitos humanos dos imigrantes como efetivação de seus próprios ordenamentos jurídicos e como estratégia de política externa podem ser base para uma política migratória não-excludente (REIS, 2011).

\subsection{Cidadania não-excludente: paradigma da mobilidade}

A cidadania nacional refere-se a indivíduos ligados entre si pelo pertencimento a uma comunidade, a nação. Estes indivíduos compartilham direitos e deveres, o que coloca a todos num plano de igualdade (COLLO; SESSI, 2001). O individualismo, a igualdade e a solidariedade presentes nessa definição hoje já não são capazes de esconder a exclusão original que o conceito encerra, ao diferenciar nacionais de estrangeiros. As implicações que os processos globais trazem para a cidadania e para democracia são vastas e profundas. A começar pela própria legitimidade moral das democracias liberais contemporâneas fundadas sobre os direitos humanos (PÉCOUD: GUCHTENEIRE, 2006a).

\footnotetext{
${ }^{144}$ Em entrevista, o representante brasileiro nestas negociações afirmou que a questão que preocupava o Paraguai era a situação dos chamados "brasiguaios" e as consequências da regularização migratória deles através do futuro Acordo.
} 
Ao longo deste texto já foi realizado um diagnóstico sobre como as políticas migratórias se estruturam em torno da irregularidade, caracterizando as migrações como um problema, o que abre o caminho para a criminalização e facilita a implantação de políticas seletivas. Cabe questionar, então, as possibilidades de superação da realidade diagnosticada, no sentido de obter maior efetividade dos direitos humanos e de implementar novos paradigmas sobre a mobilidade humana. A resposta não está na superfície das regras sobre a cidadania, mas na profundidade do paradigma que a sustenta. Squire (2011) defende a abordagem da Mobilizing Politics que inclui tanto a politização da mobilidade quanto tornar a política móvel, referindo-se a uma mudança no que significa ser político.

Mezzadra (2006), por sua vez, ao falar de um direito de fuga, traz ao centro do debate as determinações subjetivas dos movimentos migratórios. Assim, ressalta novas práticas políticas - discussão que se realiza também a respeito dos novos movimentos que se manifestam em protestos como o Occupy Wall Street ou os protestos de junho 2013 no Brasil (CAVA, 2012). São sujeitos destas práticas, indivíduos a quem formalmente se nega voz. No terreno político, e portanto conflitual, que são as migrações, onde interesses divergentes se manifestam, os migrantes reivindicam essa voz, tornam-se atores das relações internacionais (WIHTOL DE WENDEN, 2013) e impõem a consideração de sua subjetividade na regulação do tema. Se as suas reivindicações se concretizarão na forma do reconhecimento de um direito à mobilidade (PÉCOUD: GUCHTENEIRE, 2006a); de um direito de fuga (MEZZADRA, 2006); pela redefinição dos contornos da política da mobilidade (SQUIRE, 2011); ou ainda pela reconstrução da cidadania sob o paradigma da mobilidade ainda é incerto. Os contornos do que resultará desse movimento contra a vitimização, a invisibilização e/ou criminalização dos migrantes ainda não são bem definidos, o que se busca ainda não possui um nome (SCHILLING, 2001). Squire (2011), no entanto, explicita a diferença desta abordagem:

\footnotetext{
Se a irregularidade é vista simplesmente como um objeto da segurança, a mobilidade tende a reduzir-se à circulação e a cidadania invocada como um regime de controle. Por outro lado, se a irregularidade é simplesmente vista como um tema de cidadania, a mobilidade pode ser transformada politicamente, mas sob o risco de consolidar um processo em que a migração se torna "suspeita". Para tentar fugir desta armadilha, uma abordagem baseada na análise da irregularidade trabalha nas intersecções da mobilidade, cidadania e segurança para expor as lutas que permitem um repensamento da política através da irregularidade. Resumindo, uma abordagem que propõe uma análise da irregularidade diagnostica e criticamente intervém na política da mobilidade, tanto através da "politização da mobilidade", quanto através da mobilização da política (tradução livre) ${ }^{145}$.
}

145 (...) if irregularity is viewed simply as an object of security, mobility tends to be reduced to circulation and citizenship invoked as a regime of control. Conversely, if irregularity is simply viewed as a subject of 
Por sua vez, um direito à mobilidade não significaria mais um direito a adicionar ao rol de direitos de todo ser humano e sim um incentivo ao respeito dos direitos já existentes como o direito à livre escolha do emprego (art. 23 da Declaração Universal dos Direitos Humanos) e a um adequado padrão de vida (art. 25 da Declaração Universal dos Direitos Humanos) (PÉCOUD: GUCHTENEIRE, 2006a). Nesse sentido, cabe mais falar em um paradigma da mobilidade aplicado às migrações, com implicações na cidadania, na segurança e em diversas outras políticas a estas relacionadas.

A migração é um campo de luta e de construção de novas cidadanias por parte dos que não são parte, mas a clareza sobre como as diferenças e hierarquizações foram criadas pelo colonialismo e como servem ainda hoje ao disciplinamento e à exploração e à dominação do capitalismo, também é importante para nos restituir a dimensão material destes novos conflitos (MELLINO, 2013). Eles se desenvolvem no campo de uma dinâmica migratória que é parte dos processos sociais cada vez mais transnacionais. Esta dimensão material compõe a ambivalência dos processos migratórios como campo de luta pela liberdade, mas permeado por relações de exploração e dominação. Esta concreta reinvindicação de liberdade que aí se estabelece revela as engrenagens de um sistema produtivo baseado grandemente no trabalho migrante e no trabalho precário, de forma geral. São lutas convergentes, mas o espaço dessa convergência ainda está por ser construído (MEZZADRA, 2006).

$\mathrm{O}$ "direito de fuga" refere-se a um conjunto de comportamentos sociais dos sujeitos migrantes que se exprimem em formas de reivindicações de direitos. Parte destas são, por vezes reconhecidas pela ordem jurídica ou pela cidadania institucionalizada, mas há um resto estrutural que excede as retóricas da integração social e do multiculturalismo - o qual não questiona os pressupostos da exclusão (MEZZADRA, 2006). Nesse sentido, é necessária uma discussão a respeito de cultura e identidade, que acaba tocando no ponto crucial: o nacionalismo, base da cidadania.

Para esta construção do paradigma da mobilidade, a política de identidade, ligada ao comunitarismo não cabe, mas a política da neutralidade da lei, ligada ao universalismo também não é suficiente. A lei nacional e sua cidadania moderna, com base neste último mascaram a cisão que constitui o político. Nesse sentido, não há uma rejeição ao universal,

citizenship, mobility may be transformed politically, but at the risk of consolidating a process in which migration is rendered 'suspect'. In an attempt to evade such a trap, an approach based on the analytic of irregularity works at the intersections of mobility, citizenship and security in order to expose struggles that allow for a re-thinking of mobility through irregularity. To put it simply, an approach that proposes an analytic of irregularity diagnoses and criticaly intervenes in a politics of mobility both through politicizing mobility and through mobilizg politics. 
pelo contrário, mas este é visto como uma forma abstrata e a partir de uma ideia de igualdade sempre ligada à liberdade, gera luta contra o que não é tolerável, contra a dominação, cujos resultados não são pré-determinados (MEZZADRA, 2006). As resistências são inúmeras, mas a história se constitui dessa forma, através das lutas do povo contra o poder, conquistando seu legítimo espaço fundante do poder governamental e suas instituições.

A constituição de uma cidadania não excludente a partir do paradigma da mobilidade certamente incide em diversos níveis da política. A própria concepção da cidadania como prática e não como status derivado do atendimento de determinados requisitos, a superação das fronteiras como barreira no acesso à cidadania do que deriva a cooperação como integração e não dominação. A experiência da América do Sul com o Acordo de Residência, como já se viu, possui alguns traços iniciais do que poderia vir a ser essa transformação da cidadania a partir do tratamento das migrações.

Segundo o British Council sponsored 'integration index', o acesso à nacionalidade, o combate à discriminação, a reunião familiar, o acesso ao mercado de trabalho, a residência permanente e a participação política determinarão a vida que o imigrante poderá ter no país de recepção, se ele poderá desenvolver sua capacidade profissional, se poderá ter uma boa remuneração, se poderá exercitar e compartilhar a sua cultura e os seus modos de vida, ao mesmo tempo em que conhece e aprende novos hábitos e tradições da cultura local (CHAPPEL; GLENNIE, 2009).

As políticas migratórias nacionalistas mobilizam fortemente o discurso da ameaça à coesão nacional trazido pelos migrantes. $\mathrm{Na}$ perspectiva comunitarista, o sentido de pertencimento é um imperativo, então é necessário controlar quem faz parte de dada comunidade e quem não faz (PÉCOUD; GUCHTENEIRE, 2006a). A ameaça é definida segundo a ideologia nacionalista, como revela a já mencionada história do Brasil. No entanto, a história do Brasil também nos mostra que a coesão social não foi afetada pela chegada dos migrantes, ao contrário, e que o nacionalismo que embasou a política brasileira durante grande parte da sua história foi apenas instrumento de controle e hierarquização de culturas.

O debate a respeito da insuficiência do critério nacional para a cidadania não é tão recente. À época da criação da cidadania europeia, esta foi muito festejada como uma inovação. Os seus limites, no entanto, não demoraram a aparecer, refletindo também os limites do próprio processo regional, que apesar de suas transformações, nunca abandonou a centralidade comercial. A cidadania europeia, sabe-se hoje, é uma cidadania a critério nacional e economicamente fundamentada, ou seja, possui dois grandes níveis de exclusão. Assim, mantém a forma de um status adquirido mediante a loteria da nacionalidade, e em 
termos de mobilidade, é um privilégio tendo em vista a amplitude do espaço a que se tem acesso a partir da titularidade destes status (BARALDI, 2011).

As discussões a respeito das assimetrias na distribuição do direito à mobilidade apontam que alguns, nacionais de países ricos, dispõe amplamente deste. Outros, de países menos desenvolvidos, dependem de vistos, permissões de residência para poder deslocar-se (PÉCOUD: GUCHTENEIRE, 2006a). É verdade que o direito à mobilidade é distribuído de forma desigual segundo o critério da nacionalidade articulado com idade, raça, gênero e classe, mas no caso da atual legislação brasileira, as barreiras atingem também os nacionais de países desenvolvidos em fuga da crise. A lógica do interesse nacional que faz com que, por exemplo, o pedido de autorização de trabalho tenha que ser tramitado pela empresa antes que o trabalhador chegue ao país e a burocracia a ser cumprida para este trâmite acabam atingindo os projetos migratórios destas pessoas também.

No que se refere à regulação regional, esta é uma armadilha que a cidadania sulamericana deve evitar, não mantendo a diferenciação — hoje existente no Brasil — entre os povos latino-americanos dentro do processo de integração regional e os demais. Quando se fala de paradigma da mobilidade, cidadania como prática e política migratória baseada em direitos, essas distinções não cabem.

Na Europa, o estatuto de direitos do trabalhador do mercado comum foi o embrião da cidadania europeia. Ainda que o Tratado de Roma de 1957, no seu preâmbulo, já mencionasse objetivos mais amplos do que a Comunidade econômica então existente, o que se tinha de concreto à época eram os direitos do trabalhador, fator de produção, em circulação pelo mercado comum europeu (MAGNETTE, 1999).

Em 1992, foi criada a cidadania europeia pelo Tratado de Maastricht. A partir desta data, o direito de circulação e residência não derivava mais do exercício de uma atividade econômica, mas do status de cidadania reconhecido aos nacionais dos países membros (art. 18 TCE). Essa transformação, para os migrantes, é mais simbólica do que concreta. Para poder estabelecer-se em outro país da União, ainda é preciso comprovar renda mínima e posse de seguro saúde. O próprio tratado traz essa previsão.

O Tratado de Maastricht previu ainda alguns novos direitos para os cidadãos europeus (art. 20 e 21 TCE, atuais 23 a 25 do TFUE). São eles, a proteção diplomática fora da UE por outro Estado-Membro $^{146}$, o direito de utilizar qualquer uma das línguas oficiais ao se dirigir às

${ }^{146}$ A disposição aprovada prevê um mecanismo de proteção recíproca, mais que comum. Espécie de "protection 
instituições ou órgãos europeus, obtendo resposta na mesma língua; o direito de petição ao Parlamento Europeu (PE) e o acesso ao Provedor de Justiça. Estes últimos, no entanto, não são exclusivos dos cidadãos europeus. No próprio tratado a sua titularidade do direito a "qualquer cidadão da União, bem como qualquer outra pessoa singular ou coletiva com residência ou sede estatutária num Estado-Membro" (art. 194 e 195 TCE). A residência em um Estado-Membro da União, cidadãos não-europeus, no entanto, é regulada de forma individual por cada um dos Estados-membros.

Dizia-se, no início das discussões sobre a "Europa dos cidadãos" que a cidadania europeia e os direitos que trazia consigo buscava assim, "[d]esenvolver a possibilidade de identificação com a construção européia, reforçando em cada indivíduo a consciência do seu pertencimento, não somente à uma nação, mas também a uma Comunidade mais vasta ${ }^{147}$ ", construindo então uma ligação com esse ente político supranacional e inédito, a União Européia.

Com o desenvolvimento e a ampliação das competências da União Europeia um dos grande debates que se estabeleceu foi relativamente ao déficit democrático criado na medida em que inúmeras decisões políticas e normativas são tomadas por burocratas não submetidos à legitimação popular. Assim, o direito ao voto e à elegibilidade nas eleições do Parlamento Europeu (PE), buscou desenvolver a participação do cidadão comunitário à vida política da UE. Queria-se ver neste processo, uma dinâmica diferente da nacionalidade - posição passiva de diferenciação -, entendendo a cidadania como um fator de coesão social a partir da participação consciente à vida política e da adesão a uma Comunidade de fins, como é o caso da experiência européia (TRIGGIANI, 2007), mas a cidadania europeia não foi capaz de construir esta nova dinâmica.

Os direitos políticos do cidadão europeu eram por alguns concebidos de duas formas diferentes a) como corolários das liberdades econômicas de circulação, e por outros, b) como aspectos de uma integração política (MAGNETTE, 1999). No primeiro caso, mais que fundamentação teórica, esta concepção permitia implementá-los sem ter que recorrer a reformas de tratados. Reconhecê-los, no entanto, seria, de toda forma um passo importante na consolidação de uma integração política.

\footnotetext{
diplomatique déléguée" com caráter de permanência automatismo. ADAM (1992) A proteção diretamente pela União foi rejeitada pois implicava que a União fosse dotada de uma personalidade jurídica, de uma política exterior e de uma estrutura diplomática. MAGNETTE (1999).

${ }^{147} \mathrm{O}$ objetivo de identificação dirige-se tanto ao interno quanto ao externo. A liberdade de ingresso e residência e eleitorado passivo e ativo nas eleições municipais e europeias buscam aumentar a integração interna. Já a proteção diplomática comunitária permite demarcar a unidade em relação ao externo ADAM (1992).
} 
A realidade sul-americana é bastante diferente deste quadro. O Mercosul é um bloco eminentemente intergovernamental. As reivindicações dos imigrantes na América do Sul não vão no sentido de participação na institucionalidade do Mercosul, que é muito baixa ${ }^{148}$, mas sim na expansão dos destinatários da livre circulação e no seu aprofundamento ${ }^{149}$, solicitando, por exemplo, a extinção da fase provisória da residência, e a obtenção diretamente da residência permanente e a efetivação da igualdade de direitos com os nacionais que vai desde a utilização dos mesmos serviços de identificação dos brasileiros - com os mesmos prazos até o direito ao voto nas eleições do país. A implementação destas demandas em todos os países do continente configuraria de fato uma cidadania sul-americana, sem as elocubrações a respeito de união política como ocorreu na União Europeia.

Como já se viu, o Estado Nacional não foi destituído por nenhum outro ente político e ainda hoje é responsável grandemente pela criação do direito, e implementação de políticas mediante os orçamentos públicos. Existem, no entanto, forças de transformação da cidadania agindo a partir da base em um contexto de relações sociais em mutação. Reconhecer essa força e essas novas demandas é verdadeiramente propor uma inovação política a partir das mudanças a que a ordem política está submetida, fazendo-a avançar em benefício das pessoas e não dos mercados.

Além disso, como apontado, as questões que fundamentam a ideia de cidadania regional na Europa e na América do Sul são diferentes. Na Europa, além de potencialmente constituir um elemento da estratégia federalista, em curto prazo os direitos políticos atendiam a um objetivo de democratizar o nível supranacional e, dado o direito à livre circulação, garantir um mínimo de direitos políticos a todos os europeus, inclusive os que residissem fora de seu Estado de nacionalidade. Em ambos os casos, detecta-se a existência de um déficit democrático. No primeiro caso, como já se viu, derivado da expansão das capacidades decisórias e políticas da UE e no segundo caso, derivado da mobilidade dos cidadãos.

No âmbito do Mercosul e ainda mais claramente da Unasul, há pouca discussão a respeito de um déficit democrático do primeiro tipo, pois, de fato, grande parte das decisões são adotadas por consenso e quase todas precisam ser internalizadas. Deste modo, a demanda é de participação nos próprios Estados nacionais de destino, mas de forma muito mais

\footnotetext{
${ }^{148}$ Esta afirmação não possui qualquer juízo de valor. A comparação aqui realizada baseia-se no pressuposto de que as diferentes experiências são laboratórios de idéias e situações, jamais receita a ser transpostas e cumpridas. ${ }^{149}$ Em Audiência Pública realizada na Câmara Municipal de São Paulo, a finalidade dos Acordos de Residência do Mercosul (ver p. 92) foi questionada nos seguintes termos: " se é de fato para permitir o livre trânsito porque é considerado os dois primeiros anos o migrante como "temporário", [questionamento] por motivo das dificuldades para renovação do visto para permanente". Ver IMIGRANTES..., 2013.
} 
profunda do que a proposta pela cidadania europeia, além, obviamente, do reconhecimento e da garantia de direitos nos países de destino. Ou seja, a discussão é muito menos da participação democrática em diferentes níveis decisórios e mais da garantia de direitos e participação democrática que se ajuste ao paradigma da mobilidade.

Na Europa, a participação proposta em razão da mobilidade das pessoas mostrou-se ainda mais limitada a partir de sua regulamentação. A Diretiva 80 de 1994 que regulamenta o direito ao voto nas eleições municipais se limita a afirmar a possibilidade de que a participação às eleições municipais seja estendida também a nacionais de países terceiros residentes legalmente no seu território ${ }^{150}$, quando um Estado-Membro considerar oportuno. Além disso, foram previstas derrogações ao regime geral dos cidadãos europeus. A previsão do art. 14, n. 1 da Diretiva 109, de 1993, por exemplo, permite aos Estados-Membros cuja proporção de cidadãos europeus em idade de votar supere os $20 \%$ do total do eleitorado reservar o direito de voto aos eleitores com residência mínima de não mais do que cinco anos e o direito de elegibilidade aos cidadãos com uma residência mínima que não pode superar os dez anos. Previsão similar também existe na diretiva relativa ao direito de voto nas eleições municipais, n. 80, de 1994, onde os prazos de residência mínima são limitados à duração de um mandato para o voto ativo e de dois mandatos para a elegibilidade (art. 12, n.1).

À época, esta era uma preocupação principalmente à Luxemburgo que possuía uma população não nacional que variava entre $20 \%$ e $30 \%$ do eleitorado. O Conselho e a Comissão justificavam a previsão com a intenção de evitar situações de polarização entre listas "nacionais" e "não nacionais". É interessante notar como a mentalidade nacional é resistente. O transnacionalismo que está presente nas relações sociais contemporâneas não é algo que se substitui automaticamente e perfeitamente ao nacionalismo. Mesmo os imigrantes continuam de certa forma em muitas situações a reproduzir uma lógica e uma metodologia nacional em suas vidas, mostrando que a mudança de paradigma é um processo longo e profundo. Isso também não é sem razão, uma vez que quotidianamente eles são lembrados de suas diferenças, de modo que faz sentido que se juntem aos seus "iguais".

Assim, um dos principais traços da cidadania europeia que era o de postular "uma visão de inclusão e participação democrática igualitária em uma comunidade em que a diferença é valorizada e apreciada - e não simplesmente tolerada” (KOSTAKOPOULOU,

\footnotetext{
${ }^{150}$ Antes, a diferenciação relativa à posse de direitos de cidadania ocorria entre nacionais e estrangeiros. Hoje, nos países europeus há uma diferenciação a mais entre estrangeiros comunitários e estrangeiros extracomunitários (que são ulteriormente divididos entre pertencentes ou não à família de um cidadão comunitário) (TRIGGIANI, 2006).
} 
2007) não se traduziu na regulação. Era festejada por ter trazido concretude ao debate sobre as necessárias transformações da cidadania em um mundo em que o vínculo de nacionalidade não é mais capaz de dar respostas à realidade das migrações e à complexidade das ligações jurídicas que são estabelecidas em decorrência disto, mas reminiscências nacionalistas na configuração do instituto ainda são muito presentes. Além das derrogações e limitações já citadas que constroem uma cidadania desenhada para não atingir o sentimento nacional, há a exclusão flagrante dos residentes nacionais de países não-comunitários da cidadania. A lógica vigente com relação a eles não possui nenhuma novidade, é a da separação entre nacionais, no caso, nacionais comunitários, e estrangeiros.

O reconhecimento da imigração como questão política e a atribuição de direitos aos imigrantes, como elemento da construção desta nova cidadania plural, múltipla e inclusiva não existia (DE LUCAS, 2003). A dificuldade de fazer avançar certas medidas que modificam paradigmas seculares poderia levar a crer que esta restrição tendesse a ser superada com o tempo. No entanto, a direção tomada pela Europa, notadamente, através de sua política imigratória, refuta essa crença. Hoje, a cidadania europeia restritiva e subsidiária dos interesses econômicos não amalgama os cidadãos europeus (DÉLOYE, 1998) nem inclui os imigrantes.

O receio dos países de serem invadidos por hordas de migrantes é a fantasia do medo que acompanha a rejeição ao paradigma da mobilidade. Ocorre que as pessoas não migram sem necessidade, nem para onde não haja oportunidades. Além disso, as barreiras à entrada, exigência de vistos, etc. são incentivos à permanência dos migrantes, uma tentativa de garantir a migração "conquistada" a duras penas (CORNELIUS, 2001). Na Europa, havia a expectativa de migrações em massa a cada novo alargamento, o que não ocorreu. No Brasil, por exemplo, muitos migrantes bolivianos e paraguaios passam grandes temporadas em seus países de origem, retornando ao Brasil para outras temporadas de trabalho, mostrando como as barreiras à mobilidade incidem na dinâmica migratória de forma desfavorável para Estados e migrantes.

Não se ignora, no Brasil, que esta dinâmica mencionada, referente em especial ao setor das confecções, represente a transferência do peso da sazonalidade que caracteriza a indústria aos ombros dos trabalhadores. Quer-se, no entanto, sublinhar que a facilidade de entrar, sair e entrar novamente no país imprime uma dinâmica mais fluida, e que o retorno ou permanência são grandemente compatíveis com as oportunidades disponíveis. Quanto à fiscalização sobre a exploração do trabalho, como já se pontuou neste trabalho, o âmbito de análise é outro e de forma alguma deve impactar sobre a regulação dos movimentos migratórios. 
Desta forma, não somente a imposição de vistos com inúmeros requisitos somada à fortes controles de verificação do status migratório nas fronteiras e dentro do território, mas também o excesso de enquadramentos, requisitos de legitimidade para migrar, documentos de comprovação vão na contramão de uma política migratória baseada no paradigma da mobilidade. Estas previsões de tipos de migrantes e vistos, com suas respectivas exigências, submetem a migração a uma exigência central, justificar-se. Em verdade, a passagem para um paradigma da mobilidade supera isto. Como já apontado, no dia a dia é fácil verificar o quanto a vida das pessoas é dinâmica e transforma-se. Alguém migra "como" estudante e então recebe uma proposta de trabalho, ou apenas decide construir sua vida em determinado país. Nesse sentido é que apontou-se que o Acordo de Residência do Mercosul ao criar uma residência temporária de dois anos não submetida a estas exigências ${ }^{151}$ caminha nessa direção.

Da mesma forma, sob o paradigma da mobilidade, não faz sentido enfatizar o reforço e a expansão do instituto do refúgio. Esta afirmação de forma alguma nega a sua importância ou visa a sua desconstrução. A proposta é inverter o raciocínio e, em lugar de reforçar uma proteção restrita a um grupo e submetida a uma série de julgamentos de legitimidade, justificativas e comprovações; defender a legitimidade da mobilidade em si mesma.

Outra forma nacionalista de lidar com as migrações é a crença em um binômio excludente entre migração e desenvolvimento. Os países desenvolvidos acreditam que a ajuda ao desenvolvimento seja uma política válida e legítima para controlar as migrações, diante da constatação da existência de grandes desigualdades no mundo. No entanto, além de, como já se viu, os valores despendidos a este título serem muito menores do que os enviados em remessas pelos próprios migrantes, sabe-se que o desenvolvimento não impede as migrações, em um primeiro momento, inclusive, as estimula. O projeto migratório demanda recursos, enquanto a transformação econômica é lenta (HAAS, 2010). Além disso, outros fatores influenciam a decisão de migrar. Assim, dispondo de mais recursos, possuindo redes de referência de outros imigrantes e vivendo em um país que não lhe oferece as oportunidades de vida que gostaria de ter, é provável, inclusive, que a imigração aumente. Dessa forma, as questões são complementares e não excludentes (CASTLES, 2010).

O discurso da ajuda ao desenvolvimento anda ao lado daquele da cooperação para a gestão das migrações. Em 1999, a UE mencionava na Declaração do Conselho Europeu de Tampere, ponto 11, que a parceria com os países terceiros deveria visar o combate à pobreza, a melhora das condições de vida e as oportunidades de emprego (enfrentamento da imigração

${ }^{151}$ A única exigência é a ausência de antecedentes criminais. 
por motivos econômicos), além da prevenção dos conflitos e da consolidação dos Estados democráticos, e a garantia do respeito dos direitos humanos, com atenção especial às minorias, às mulheres e às crianças (enfrentamento da imigração por motivos políticos), de forma genérica. Três anos mais tarde, na reunião do mesmo Conselho em Sevilha, a diretriz se concretiza e a indicação é de que "em todos os futuros acordos de cooperação, de associação ou acordos equivalentes que a União Europeia ou a Comunidade Europeia celebrar com quaisquer países, seja incluída uma cláusula relativa à gestão conjunta dos fluxos migratórios, bem como à readmissão obrigatória em caso de imigração ilegal” (ponto 33). São previstas, inclusive, punições e ameaças no sentido do não aprofundamento das relações em caso de não colaboração.

A cooperação reduz-se então a um "auxílio" imposto como moeda de troca para a obtenção de outros benefícios pelos países de origem dos migrantes. Assim opera grande parte da cooperação em matéria de migração, sob uma lógica que promove no máximo um double win entre os Estados e em que o imigrante é aquele que perde, o elemento mais frágil, negociado entre os Estados. Sob o paradigma da mobilidade, a cooperação deve assumir a forma de combate à exploração e à violência no percurso das migrações e nas relações de trabalho no país de destino. Harmonização do tratamento jurídico e nos serviços à toda a população, inclusive os migrantes, buscando a efetivação da garantia do direito a migrar concomitantemente ao direito a não migrar.

Finalmente, as políticas migratórias tradicionais reforçam as fronteiras, que para além das exceções, implementam ações padronizadas e quotidianas para a produção de irregularidade. Nesse processo, mobilizam as hierarquizações diferenciadoras como o racismo, por exemplo (SQUIRE, 2011). Em uma relação dialética, também alimentam a diferenciação ao reforçar a ideia que estrangeiros são indesejáveis e reforçam também fronteiras internas, segundo linhas étnicas (PÉCOUD: GUCHTENEIRE, 2006a). As zonas de fronteira são lugares físicos ou virtuais marcados pela intensificação das lutas políticas sobre a condição de irregularidade (SQUIRE, 2011), são barreiras muito concretas e muito visíveis à cidadania, de forma que os migrantes mostram muito ilustrativamente que é possível superar estas barreiras, ao mesmo tempo que carregam sobre seus corpos as marcas desta batalha (MEZZADRA, 2006). 


\section{CONCLUSÃO}

Na perspectiva do paradigma da mobilidade, a fronteira deve ser um lugar de trocas e de afirmação do valor da diversidade. A construção da cidadania sul-americana a partir do Acordo de Residência pode ser um horizonte para os movimentos. Os princípios que a inspiram, a apropriação e a prática da cidadania desde baixo devem orientá-la para que não se torne excludente com quem vem de fora do continente, sob o risco de perder coerência e legitimidade. $\mathrm{O}$ reconhecimento do paradigma da mobilidade e do caráter transnacional dos espaços criados pelos imigrantes devem articular-se com a ideia de integração regional, não sendo necessariamente apropriados por ela.

Diz-se da América Latina que o continente é pródigo em discursos, mas é pouco comprometido em pô-los em prática. No caso da cidadania sul-americana, no entanto, os Acordos de Residência representam uma medida efetiva, implementada antes de que fosse construído um discurso claro e consistente sobre o tema e, em certa medida, até hoje seus efeitos não foram completamente apreendidos. $\mathrm{O}$ que já se escreveu sobre os Acordos não é capaz de registrar a transformação que estes promoveram junto às comunidades migrantes. Apenas a vivência prática pode apontar para este dado. Desde a entrada em vigor destes, o processo tem sido impulsionado a partir de baixo, sem sistematização e ainda sem um nome para o que se quer construir, o que revela o caráter o seu caráter genuíno, mas também a sua precariedade.

Se as migrações internacionais fazem parte de toda a história da humanidade e são estruturais no modo de produção capitalista, alguém pode se perguntar o que as traz para o centro das discussões políticas na atualidade. É fato que os movimentos de pessoas pelo globo não são uma novidade, mas atualmente eles se revestem de novas características. Não somente por interessarem a todas as regiões do mundo, mas também em razão de estarem inseridos e constituirem os processos transnacionais que caracterizam a chamada globalização. O transnacionalismo nas migrações chama a atenção para os múltiplos vínculos e pertencimentos que os migrantes possuem hoje, possíveis em razão da dinâmica dos deslocamentos e também graças às transformações nos meios de comunicação e meios de transporte.

Essa análise também destaca a agência ${ }^{152}$ dos migrantes no desenho e realização de seu projeto migratório, muitas vezes a despeito das regras estabelecidas para tanto. Isso traz à

\footnotetext{
${ }^{152}$ Sobre a "agência" dos imigrantes a respeito dos seus projetos migratórios, ver p. 19.
} 
tona o elemento que talvez mais incomode os Estados, a imprevisibilidade dos movimentos. Deve ficar claro que, regra geral, o interesse dos Estados não é o de zerar a entrada de migrantes. Se existem oportunidades de empregos, isto é indício das necessidades de mão de obra de um determinado mercado. Assim, as políticas se constroem de forma a poder selecionar a mão de obra necessária, e descartá-la quando não houver mais necessidade.

Nesse sentido, o conceito de irregularidade migratória serve à construção da migração internacional como um problema para o qual deve ser encontrada uma solução, através da seletividade. Disto deriva a ênfase no reforço dos controles migratórios nas fronteiras e mesmo internamente no território, expandindo as "fronteiras" no espaço e no tempo através de verificação de documentos em locais de trabalho e constantes necessidades de renovação de permissões, etc. Assim, o combate à imigração irregular o qual muitas vezes vêm lado a lado à promoção dos direitos dos migrantes no elenco de medidas das políticas, em verdade é o que legitima diversas violações e mortes de migrantes nas batalhas que se travam pelo direito à mobilidade contra a pretensão de controle dos Estados.

As migrações, nesse sentido, são um terreno extremamente conflitual no qual os migrantes lutam por liberdade e igualdade através da mobilidade. Este terreno é permeado por relações de dominação e exploração, como é possível perceber nas situações degradantes e precárias a que estão submetidos. É importante enxergar a autonomia dos imigrantes nesse processo e não criminalizá-los pela exploração que sofrem, nem vitimizá-los, desempoderando-os neste processo.

Nesse sentido, ao lado das políticas migratórias não-excludentes, cabem certamente medidas destinadas a combater a exploração do trabalho que não é uma realidade pontual ou eventual. Em geral, tal exploração é estruturante em determinados setores da economia, especialmente os intensivos em mão de obra, onde os braços migrantes são especialmente demandados. Nesta linha, políticas públicas de atenção aos migrantes também podem ser instrumentos de transformação dessa realidade, garantindo-lhes não somente o acesso a todos os serviços públicos como também mais oportunidades de transformar a realidade de exploração a que estão submetidos. Assim, capacitações profissionais e cursos do idioma local podem ser instrumentos de fortalecimento de suas lutas.

Como se viu, as implicações políticas derivadas das migrações incidem sobre os eixos estruturantes da ordem jurídica nacional e internacional e, não sem dificuldade, esta resiste. Os Estados nacionais enfrentam grande mal-estar em justificar-se frente às inúmeras violações de direitos e mortes derivadas das políticas migratórias restritivas. Assim, o discurso construído nas últimas décadas pelas Organizações Internacionais como ONU e OIM são 
úteis aos Estados na busca de uma nova alternativa para o tratamento do tema que mantenha as suas prerrogativas de controle. A mudança é sutil, o discurso da gestão das migrações é mais palatável a todos e, por vezes inclusive, passa despercebido até mesmo aos defensores dos direitos dos migrantes mais desavisados.

Os discursos de migração e desenvolvimento e do triple win game, mantêm essa premissa de controle, ao mesmo tempo em que se apresentam como políticas que atendem às demandas dos migrantes por mobilidade. Em verdade, a mobilidade governada desta forma é apenas aquela que interessa aos Estados e aos mercados, além de pouco transformarem os países de origem ou a realidade de exploração econômica a que estão submetidos os migrantes.

O reconhecimento da subjetividade dos migrantes implica em transformações mais profundas. A cidadania fundada sobre o nacionalismo não responde à realidade atual em que é a mesma é praticada pelos migrantes quotidianamente. Revelam-se, assim, os limites formais de um instituto fundado nesta exclusão. As exclusões internas das minorias articulam-se à exclusão formal a que estão submetidos os migrantes, de modo que migrantes negros e indígenas são duplamente marginalizados.

As demandas de garantia dos direitos humanos dos migrantes, assim, não se limitam a reivindicar a igualdade material, a qual é negada a pobres, negros, indígenas, mulheres, homossexuais, por exemplo; mas também a igualdade formal, o que coloca em questão o próprio desenho da cidadania e não somente as formas de efetivá-la. É nesse sentido que uma política migratória baseada nos direitos humanos precisa superar o nacionalismo metodológico e elaborar alternativas que não se apresentem apenas como discursos vazios, mas que sejam capazes de captar estas transformações das dinâmicas sociais e da cidadania e, de fato garantir os direitos humanos dos migrantes.

A questão da afirmação de direitos que são garantidos a todos os seres humanos em razão de sua condição humana em um mundo de Estados soberanos tem gerado diversas tensões ao longo de sua história. Primeiramente, colocou em questão as matérias de exclusiva jurisdição doméstica dos Estados, estabelecendo limites ao poder soberano destes em seu próprio território. Ao longo dos anos, questões como a emergência do indivíduo como sujeito de direito internacional; a submissão a tribunais internacionais; entre outras, derivam da afirmação destes direitos.

A dinâmica do direito também não ficou imune às transformações trazidas pelos processos globais e o processo de internacionalização do direito através do qual cresce o número de normas, em especial as econômicas, produzidas em nível internacional, tem gerado 
preocupações relativas ao desconhecimento dos direitos humanos neste processo. Reflexões sobre como enfrentar estes desafios são muitas, passam por propostas normativas, institucionais, filosóficas, etc. A necessidade de democratizar ou constitucionalizar a ordem internacional, em todos os casos, é uma constante.

O desafio à ordem política colocado pelas migrações, por outro lado, parte de baixo. A experiência da cidadania europeia frustrou as expectativas de uma inovação na resposta a esse desafio, relativamente à garantia de direitos humanos. Ligada fortemente à ampla institucionalidade da União Europeia, ela é pobre em direitos próprios e apenas expande a aplicação do critério da nacionalidade na definição dos cidadãos europeus. O controle da mobilidade é reforçado na mesma medida do reforço do seu caráter excludente.

Na América do Sul, o discurso da garantia de direitos humanos dos migrantes tem ganhado força nos últimos anos. Na Argentina ${ }^{153}$ e no Uruguai ${ }^{154}$ já vigem leis migratórias construídas sob este paradigma. Todos os estados do subcontinente sul-americano ratificaram a Convenção da ONU sobre Trabalhadores Migrantes, à exceção do Brasil, da Venezuela e do Suriname.

O Brasil encontra-se, talvez, no momento de maior probabilidade de substituição da sua legislação arcaica sobre o tema, nos últimos trinta anos. O caráter obsoleto desta é notório entre os estudiosos e operadores do tema. Até recentemente, no entanto, as migrações no Brasil eram um tema completamente invisível à opinião pública e despertavam pouco interesse de parlamentares e outros atores governamentais. $\mathrm{O}$ discurso dos atuais operadores da política, conforme se verificou, é consistente no sentido de que a diretriz para uma nova lei e uma nova política deva ser a garantia dos direitos humanos dos migrantes. As formas de concretização desta diretriz, capazes de revelar o alcance desta, é que estão pouco definidas até o momento.

Há, no entanto, uma normativa concreta vigente que aponta para uma mudança de paradigma, tendo a mobilidade como parâmetro. Os Acordos de Residência do Mercosul, vigentes desde 2009 e atualmente incluindo os Estados membros (à exceção da Venezuela), a Bolívia, o Chile, o Peru, a Colômbia e o Equador, não exigem, nos dois primeiros anos de residência qualquer justificativa sobre os motivos da migração. Trata-se de uma pista sobre a implementação do paradigma da mobilidade. Fala-se de pista, pois elementos antigos persistem, como a necessidade de transformação da residência em permanente após dois anos

\footnotetext{
${ }^{153}$ Ley 25.871 de 2004.

${ }^{154}$ Ley 18.250 de 2008.
} 
e mediante comprovação de possuir meios lícitos de subsistência. Além disso, para uma verdadeira transformação de paradigma, será necessário evitar o erro da cidadania europeia que insiste no parâmetro nacional-excludente para definir os seus contornos.

Desta forma, o prisma do Brasil e da América do Sul sobre as migrações confirma a pertinência das teorias sobre o transnacionalismo e a autonomia das migrações, agregando a estas uma experiência concreta, a dos Acordos de Residência do Mercosul. O caminho para que as pressões às quais diversas instituições políticas - em especial a cidadania - estão submetidas revertam-se em transformações condizentes com um novo paradigma capaz de garantir efetivamente os direitos humanos de todos é o que se busca. Quem o conhece são os próprios sujeitos que quotidianamente travam estas lutas. 


\section{ANEXO \\ Questionário aplicado aos entrevistados}

1. Você considera que o Brasil possui uma política para as migrações atualmente? Sim Quais são os principais elementos desta? Não - Quais são as principais questões a serem enfrentadas por uma futura política. Qual a sua avaliação a respeito do projeto para atração de migração qualificada que está sendo elaborado pela SAE?

2. Você tem conhecimento dos dados oficiais sobre o fluxo migratório atual? Qual a leitura que pode fazer destes no que se refere ao seu volume e às suas características relativas à qualificação, origem nacional, classe social, setor econômico de atuação, etc.? Para os imigrantes pouco qualificados, qual deve ser o tratamento diante das poucas possibilidades regulares de imigrar, as quais não impedem a sua entrada?

3. Você percebe manifestações da sociedade sobre as migrações? Em que sentido e qual a importância destas na definição da política? As diferentes opiniões são compatíveis dentro de uma mesma política e/ou recebem a mesma atenção do governo? $t$

4. De que forma a preocupação com o controle das fronteiras (entrada de armas, drogas, contrabando) e a segurança nacional se relaciona com o tema da regulação das migrações internacionais no Brasil hoje?

4.1 É possível evitar que haja violação dos direitos humanos dos imigrantes que entram irregularmente no país e que muitas vezes recorrem aos chamados coyotes?

5. As sanções hoje adotadas pelo Estado à exploração do trabalho imigrante (p. ex. fechamento de oficinas de costura, aplicação de multas, etc.), na sua opinião, são suficientes para coibir as violações? Não - quais outras poderiam ser tomadas. Sim - por que avalia que as violações continuam crescendo? Trata-se de uma exploração pontual ou uma característica do capitalismo?

6. Na sua opinião, o Brasil deve implementar políticas de integração social para a população imigrante? Quais prioritariamente? E qual a sua importância?

7. A respeito da Lei $6815 / 80$, o Estatuto do Estrangeiro. Por que essa legislação permanece em vigor até hoje? O que impede e o que estimula a aprovação de uma nova legislação?

8. Na sua opinião, dentre os direitos garantidos para os nacionais brasileiros, há algum que não deveria ser garantido aos estrangeiros? E em relação aos direitos políticos?

9. Outro documento relevante na regulação da matéria é o Acordo de Residência do Mercosul, assinado em 2002 e vigente desde 2009. O que motivou a assinatura deste acordo? Que fatores políticos ou econômicos permitiram superar as restrições do Estatuto do Estrangeiro? O que o Brasil tinha a ganhar com este acordo?

9.1 Seus objetivos são compatíveis com a política migratória do Brasil? Qual a importância da cooperação/integração em matéria migratória?

10. Percentualmente a presença de imigrantes no Brasil ainda é muito menor que a dos principais receptores de imigração (EUA, Europeus, Austrália, etc.). Você acredita que 
chegaremos nestes níveis e, na sua opinião, esta realidade demandaria outras medidas políticas? 


\section{REFERÊNCIAS}

\section{Livros, artigos e relatórios}

ADAM, Roberto. Prime riflessioni sulla cittadinanza dell'Unione. In: Rivista di Diritto Internazionale, vol. LXXV, 1992.

AGUNIAS, Dovelyn R.; NEWLAND, Kathleen. Circular Migration and Development: Trends, Policy Routes and Ways Forward. In: Policy Brief. Migration Policy Institute, April 2007.

ALFONSO, Adriana. Integración y Migraciones. El tratamiento de la variable migratoria en el MERCOSUR y su incidencia en la política argentina. In: OIM - Cuadernos Migratorios, $\mathrm{n}^{\circ}$ 3,2012 .

AMARAL JÚNIOR, Alberto do. Introdução ao Direito Internacional Público. São Paulo: Ed. Atlas, 2008.

AMNESTY INTERNATIONAL; HUMAN RIGHTS WATCH. Statement by Amnesty International \& Human Rights Watch: Governing Council, International Organization for Migration. 2-4 de dezembro de 2002. Disponível em: https://www.amnesty.org/es/library/asset/IOR42/006/2002/en/d8e09dee-d774-11dd-b02421932cd2170d/ior420062002en.pdf. Acesso em: 16 mai 2014.

ANDERSON, Benedict R. Comunidades imaginadas. Reflexões sobre a origem e a difusão do nacionalismo. Trad. Denise Bottman. São Paulo: Companhia das Letras, 2008.

ARADAU, Claudia; HUYSMANS, Jef. Mobilising (global) democracy: A political reading of mobility between universal rights and the mob. In: Millennium: Journal of International Studies, vol. 37, n. 3, 2009.

ARAÚJO, Maria Amélia Aparecida. O Discurso sobre (i)migrantes da periferia de São Paulo e Paris: o dizer da mídia e suas representações. Dissertação de Mestrado. UNICAMP, 2011.

ARCHIBUGI, Cosmopolitan Democracy and its Critics: a review. In: European Journal of International Relations. Vol. 10 n. 3, 2004.

ARENDT, Hannah. O que é Política? 3ª ed. Rio de Janeiro: Bertrand Brasil, 2002. 
ARENDT, Hannah. Crises da República. 2.ed. São Paulo: Editora Perspectiva, 2004.

BARALDI, Camila. Cidadania, Migrações e Integração Regional - Notas sobre o Brasil, o Mercosul e a União Européia. Trabalho apresentado no $3^{\circ}$ Encontro Nacional da Associação Brasileira de Relações Internacionais. São Paulo, 2011.

BARALDI, Camila; VENTURA, Deisy. Políticas Migratórias e Tráfico de Pessoas: quando a árvore esconde a floresta. In: ANJOS, Fernanda Alves dos et al. (Orgs.) Tráfico de pessoas: uma abordagem para os direitos humanos. 1.ed. Brasília: Ministério da Justiça, 2013.

BARALDI, Camila; ALMEIDA, Táli Pires de; WALDMAN, Tatiana. O direito dos imigrantes ao Benefício de Prestação Continuada: uma questão de cidadania. In: ASSISTÊNCIA SOCIAL: análise do direito fundamental a partir da experiência de 20 anos da Lei 8.472/93. No prelo.

BAKEWELL, Oliver. Some reflections on Structure and agency in migration theory. In: Journal of Ethnic \& Migration Studies. Vol. 36 n.10, 2010.

BENHABIB, Seyla. The Rights of others. Aliens, Residents and Citizens. Cambridge: Cambridge University Press, 2004.

BIGO, Didier. Security and Immigration: Toward a Critique of the Governamentality of Unease. In: Alternatives, n. 27, 2002.

BIGO, Didier. Freedom and speed in enlarged zones. In: SQUIRE, Vicki. The Contested Politics of Mobility: Borderzones and Irregularity. London: Routledge, 2011.

BLEICH, Erik. Integrating Ideas into Policy-Making Analysis: Frames and Race Policies in Britain and France. In: Comparative Political Studies. Vol. 35, n. 9, 2002.

BOBBIO, Norberto. A era dos direitos. Trad. Carlos Nelson Coutinho. Nova ed. Rio de Janeiro: Elsevier, 2004.

BONAVIDES, Paulo. Ciência Política. 10a edição. São Paulo: Malheiros, 2003.

BOHNING, R. The ILO and the new UN convention on migrant workers: The past and future. International Migration Review, 1991. 
BOSNIAK, L. S. Human rights, state sovereignty and the protection of undocumented migrants under the International Migrant Workers Convention. International Migration Review, 1991.

BOSWELL et al. The Role of Narratives in Migration Policy-Making: A Research Framework. In: The British Journal of Politics and International Relations. Vol. 13. 2011.

BOUBEKER, Ahmed. L'héritage de l'immigration postcoloniale comme expérience vécue, Amnis - Revue de civilisation contemporaine Europes/Amériques, vol. 7, 2007.

BRASIL, Ministério da Saúde. Cartão Nacional de Saúde. Normas e Procedimentos de Uso. Brasília, 2011.

BRUM, Eliane. A nudez por trás do jaleco. Revista Época, 02 set 2013.

BRUSH, Barbara L.; SOCHALSKY, Julie. International Nurse Migration: Lessons From the Philippines. In: Policy Politics \& Nursing Practice, vol. 8, n. 1, 2007.

CAILLAULT, Clotilde. The Implementation of Coherent Migration Management Through IOM Programs in Morocco. In: GEIGER, Martin; PÉCOUD, Antoine (org.). The new Politics of International Mobility. Migration Management and its discontents. Special Issue. IMIS Beiträge, Heft 40, 2012.

CASSESE, Antoni. Diritto Internazionale. Bologna: Il Mulino, 2006.

CASTILHO, E. W. V. Tráfico de pessoas: da Convenção de Genebra ao Protocolo de Palermo, 2008.

CASTLES, Stephen. Why migration policies fail. Ethnic and Racial Studies. Vol. 27, n. 2, 2004.

CASTLES, Stephen. Guestworkers in Europe: a Ressurection? In: International Migration Review. Vol. 40, n. 4, 2006.

CASTLES, Stephen. Twenty-first-century migration as a challenge to sociology. In: Journal of Ethnic and Migration Studies. Vol. 33, n. 3, 2007. 
CASTLES, Stephen. Understanding Global Migration: A Social Transformation Perspective. Journal of Ethnic and Migration Studies. Vol. 36, $\mathrm{n}^{\mathrm{o}}$ 10, 2010.

CASTLES, Stephen; MILLER, Mark J. The age of Migration. International Population Movements in the Modern World. $4^{\text {th }}$ Edition. Palgrave Macmillan, 2009.

CASSESE, Antonio. Diritto Internazionale. A cura di Paola Gaeta. Bologna: Il Mulino, 2006.

CAVA, Bruno. A coruja voa de tarde: a ontologia comunista do fazer-se da multidão. In: Revista Eco Pós, vol. 15, n. 2, 2012.

CHAPPELL, Laura; GLENNIE, Alex. Maximising the Development Outcomes of Migration: a Policy Perspective. In: UNDP. Human Development Reports. Research Paper 11, 2009.

CHIBBER, Vivek. Postcolonial theory and the specter of capital. Verso: New York, 2013.

CHIMNI, B. S. The geopolitics of refugee studies: A view from the South. Journal of Refugee Studies, v. 11, n. 4, 1998.

COGO, Denise. Mídia, imigração e interculturalidade: mapeando as estratégias de midiatização dos processos migratórios e das falas imigrantes no contexto brasileiro. In: Comun. Inf., vol. 4, n. 1/2, 2001.

COMISSÃO MUNDIAL SOBRE AS MIGRAÇÕES INTERNACIONAIS. As migrações num mundo interligado: novas linhas de acção. Trad. Elsa Oliveira, Lda / Carlos Fiuza. S.l: Fundação Calouste Gulbekian, 2005.

CONECTAS; MESA NACIONAL PARA LAS MIGRACIONES Y REFUGIO EN REPÚBLICA DOMINICANA - MENAMIRD. Pronunciamento oral no Conselho de Direitos Humanos da ONU. 25 ${ }^{\text {a }}$ Sessão. Março, 2014. Disponível em: http://www.conectas.org. Acesso em: 15 mai 2014.

CORNELIUS, Wayne A. Death at the Border: Efficacy and Unintended Consequences of US Immigration Control Policy. In: Population and Development Review, vol. 27, n. 4, 2001.

COSTA, Pietro. Civitas. Storia della cittadinanza in Europa. Dalla civiltà comunale al Settecento, vol. 1. Roma: Editori Laterza, 1999. 
DABÈNE, Olivier. Au-delà du régionalisme ouvert. La gauche latino-américaine face au piège de la souveraineté et de la flexibilité. In: DABÈNE, Olivier (Org.) La gauche en Amérique latine, 1998-2012. Paris: Presses de Sciences Po, 2012.

DADALTO, Maria Cristina (Coord.). A Representação Social sobre a Imigração na Mídia Brasileira - mapeamento e análise dos discursos comunicacionais. Relatório técnicocientífico final. Universidade Federal do Espírito Santo, s.d.

DE GENOVA, Nicholas P. Migrant "illegality" and deportability in everyday life. In: Annu. Rev. Anthropol. vol, 31, 2002.

DE HAAS, Hein. Turning the tide? Why 'development instead of migration' policies are bound to fail. In: International Migration Institute, Working Paper Series, n. 2, 2006.

DE HAAS, Hein. The myth of invasion: the inconvenient realities of African migration to Europe. Third World Quarterly, v. 29, n. 7, 2008.

DE HAAS, Hein. Migration and Development: a Theoretical Perspective. In: International Migration Review. Vol. 44, n. 1, 2010.

DELGADO WISE et al. Reframing the Debate on Migration, Development and Human Rights. In: Population, Space and Place. 19, 2013.

DELMAS-MARTY, Mireille. Résister, responsabiliser, anticiper. Paris: Seuil, 2013.

DÉLOYE, Yves. De la citoyenneté stato-nationale à la citoynneté européenne: quelques éléments de conceptualisation. Swiss Political Science Review. vol. 4, n. 4, 1998.

DIAS, G. M.; SPRANDEL. M. A. Reflexões sobre políticas para migracões e tráfico de pessoas no Brasil. Revista Interdisciplinar da Mobilidade Humana, v. 19, n. 37, 2011.

DUSSEL, Enrique. 20 teses de Política. Tradução: Rodrigo Rodrigues. São Paulo: Expressão Popular, 2007.

EUROPEAN UNION AGENCY FOR FUNDAMENTAL RIGHTS (FRA). Fundamental rights of migrants in an irregular situation in the European Union. Viena, 2011. 
FAIST, Thomas. Migrants as Transnational Development Agents: An Inquiry into the Newest Round of the Migration-Development Nexus. In: Population, Space and Place, n. 14, 2008.

FELDMAN, Gregory. The migration apparatus. Security, labor, and policymaking in the European Union. Stanford: Stanford University Press, 2012.

FERRAJOLI, Luigi. A soberania no mundo moderno. São Paulo: Martins Fontes, 2002.

FÓRUM SOCIAL PELA INTEGRAÇÃO E DIREITOS HUMANOS DOS MIGRANTES NO BRASIL. Manifesto em Defesa de Uma Nova Lei de Migração Pautada nos Direitos Humanos e na Solidariedade Entre os Povos, 12 de abril de 2012. Disponível em: http://www.cdhic.org.br/?p=1052

FRAGA, Mirtô. O novo Estatuto do Estrangeiro comentado. Rio de Janeiro: Forense, 1985.

FREEMAN, Gary. National Models, Policy Types, and the Politics of Immigration in Liberal Democracies. In: West European Politics. Vol. 29 n. 2, 2006.

FREIRE DA SILVA, Carlos. Trabalho informal e redes de subcontratação: dinâmicas urbanas da indústria de confecções em São Paulo, Dissertação de mestrado, Universidade de São Paulo, 2008.

GEIGER, Martin; PÉCOUD, Antoine. The Politics of International Migration Management. UK: Palgrave Macmillan, 2010.

GEIGER, Martin; PÉCOUD, Antoine. The new Politics of International Mobility. Migration Management and its discontents. Introduction. In: IMIS - Beiträge, Heft 40, 2012.

GEORGI, Fabian. For the Benefit of Some: The International Organization for Migration and its Global Migration Management. In: GEIGER, Martin; PÉCOUD, Antoine. The Politics of International Migration Management. UK: Palgrave Macmillan, 2010.

GIULIANO, Paola; RUIZ-ARRANZ, Marta. Remittances, financial development, and growth. In: Journal of Development Economics. Vol. 90, 2009.

GLICK-SCHILLER, Nina. A Global Perspective on Transnational Migration: Theorizing migration without Methodological Nationalism. In: COMPAS Working paper series $n^{\circ} 67$. 
University of Oxford, 2009.

GONÇALVES, Paulo Sergio. A Pós-graduação no Brasil nos termos do Acordo de admissão de títulos e graus universitários para o exercício de atividades acadêmicas nos Estados partes do Mercosul. Dissertação de Mestrado. Maringá: Universidade Estadual de Maringá, 2012.

GOYARD-FABRE, Simone. Os fundamentos da ordem jurídica. Trad. Claudia Berliner. São Paulo: Martins Fontes, 2007.

HASENAU, M. ILO standards on migrant workers: The fundamentals of the UN convention and their genesis. International migration review, p. 687-697, 1991.

HERRERA FLORES, Joaquín; RODRIGUEZ PRIETO, Rafael. Legalidad: explorando la nueva ciudadanía. In: AGUILAR, Tusta; CABALLERO GARCÍA, Araceli. Campos de Juego de la Ciudadanía. Madrid : El Viejo Topo, 2003.

HEWINSON, Kevin; KALLERBERG, Arne L. Precarious Work and Flexibilization in south and Southeast Asia. In: American Behavioral Scientist, 57 (4), 2012.

HYNDMAN, Jennifer; MOUNTZ, Alison. Another Brick in the Wall? Neo-Refoulement and the Externalization of Asylum by Australia and Europe. In: Government and Opposition. Vol. 43, n. 2, 2008.

HUMAN RIGHTS WATCH. NGO Background paper on the Refugee and Migration Interface, apresentado na UNHCR Global Consultations on International Protection em 2829 de junho de 2001. Disponível em: http://www.hrw.org/ Acesso em: 16 mai 2014.

HUMAN RIGHTS WATCH. Pushed Back, Pushed Around: Italy's Forced Return of Boat Migrants and Asylum Seekers, Libya's Mistreatment of Migrants and Asylum Seekers", 2009.

IBGE. Censo Demográfico 2010. Questionário Básico. 2010a.

IBGE. Censo Demográfico 2010. Questionário da Amostra. 2010b.

ILLES, Paulo; TIMÓTEO, Gabrielle Louise Soares; FIORUCCI, Elaine da Silva. Tráfico de pessoas para fins de exploração do trabalho na cidade de São Paulo. In: Cadernos Pagu, n. 31,2008 . 
INTERNATIONAL LABOUR ORGANISATION. International Migration Programme. ILO's Multilateral Framework on Labour Migration Non-binding principles and guidelines for a rights-based approach to labour migration. Geneva, International Labour Office, 2006.

INTERNATIONAL ORGANIZATION FOR MIGRATION. Essentials of Migration Management. Volume One: Migration Management Foundations. Geneva: International Organization for Migration, 2004.

INTERNATIONAL ORGANIZATION FOR MIGRATION. Financial Report. For the year ended 31 December 2012. MC 2376. Em 25 abr 2013. Disponível em: http://www.iom.int/files/live/sites/iom/files/About-IOM/governing-

bodies/en/council/103/MC_2376.pdf. Acesso em: 10 mai 2014.

ISIN, Engin F.. Theorizing acts of citizenship. In: ISIN, Engin. F.; NIELSEN, Greg. M. (Ed.), Acts of Citizenship. London: Palgrave Macmillan, 2008.

JAHIC, G.; FINCKENAUER, J. O. Representations and misrepresentations of human trafficking. Trends in Organized Crime, v. 8, n. 3, 2005.

LAMPEDUSA, Tomasi di. Il Gattopardo. 97ª ed. Milano: Feltrinelli, 2011. Edição original, 1958.

LAHAV, Gallya; GUIRAUDON, Virginie. Actors and Venues in Immigration Control: Closing the Gap between Political Demands and Policy Outcomes. In: West European Politics. Vol. 29 n. 2, 2006.

LE BLANC, Guillaume. Dedans, dehors. La condition d'étranger. Paris, Seuil, 2010.

LEVY, Maris Stella Ferreira. O papel da migração internacional na evolução da população brasileira (1872-1972). In: Revista de Saúde Pública, n. 8 (supl.), 1974.

MAGALHÃES, Giovanna Modé; SCHILLING, Flavia. Imigrantes da Bolívia na escola em São Paulo: fronteiras do direito à educação. In: Pró-Posições, Campinas, vol. 23, n. 1 (67), 2012.

MAGNETTE, Paul. La citoyenneté européenne. Éditions de l'Université de Bruxelles, 1999. 
MAMED, Letícia Helena; LIMA, Eurenice Oliveira de. Trabalho e Migração Internacional: 0 caso dos haitianos na Amazônia Ocidental. Disponível em: http://actacientifica.servicioit.cl/biblioteca/gt/GT9/GT9_MamedLOliveiraE.pdf. Acesso em 4 mai 2014.

MARTIN, Susan. A Nation of Immigrants. Cambridge University Press: New York, 2011.

MELLINO, Miguel. Cittadinanze postcoloniali. Appartenenze, razza e razzismo in Europa e Italia. Roma: Carocci editore, 2012.

MEYERS, Eytan. Theories of International Migration Policy - A Comparative Analysis. In: International Migration Review, Vol.. 34, nº 4, 2000.

MARSHALL, T. H. Cidadania, classe social e status. Trad. Meton Porto Gadelha. Rio de Janeiro: Zahar Editores, 1967.

MAZZUOLI, Valerio de Oliveira. A questão do reconhecimento de títulos de mestrado e doutorado provenientes dos países do Mercosul. In: Pós - Revista do Programa de PósGraduação em Arquitetura e Urbanismo da FAUUSP, vol. 18, n. 30, 2011.

MEZZADRA, Sandro. Diritto di Fuga. Migrazioni, cittadinanza, globalizzazione. Verona: Ombre Corte, 2006.

MEZZADRA, Sandro. The Gaze of Autonomy. Capitalism, Migration and Social Struggles. In: SQUIRE, Vicki. The Contested Politics of Mobility: Borderzones and Irregularity. London: Routledge, 2011.

MEZZADRA, Sandro. Movimenti indisciplinati. Migrazioni, migrant e discipline scientifiche. Verona: Ombre Corte, 2013.

MILESI, Rosita; UCHOA, Virgilio Leite. Migrantes: uma questão de direitos humanos . Os fundamentos de uma nova agenda dos migrantes. IMDH, 2001. Disponível em: http://www.migrante.org.br/. Acesso em: 15 mai 2014.

MILESI, Rosita. Vaticano lança Documento sobre Migrações "A Caridade de Cristo para com os Migrantes" (Erga Migrantes Caritas Christi). Centro Scalabriniano de Estudos Migratórios, Instituto Migrações e Direitos Humanos Pastoral dos Brasileiros no Exterior (CNBB). Brasília, 2004. 
MINISTÉRIO DA SAÚDE. Diagnóstico da saúde no Brasil. 27 set 2013. Disponível em: http://portalsaude.saude.gov.br/index.php/cidadao/acoes-e-programas/mais-medicos/maissobre-mais-medicos/5952-diagnostico-da-saude-no-brasil. Acesso em: 15 mai 2014.

MINISTÉRIO DO TRABALHO E EMPREGO. Resultados das Operações de Fiscalização para Erradicação do Trabalho Escravo, s.d. Disponível em:

http://portal.mte.gov.br/trab_escravo/resultados-das-operacoes-de-fiscalizacao-paraerradicacao-do-trabalho-escravo.htm. Acesso em: 15 mai 2014

MORGAN, Kristi L. Evaluating Guest Worker Programs in the U.S.: A Comparison of the Bracero Program and President Bush's Proposed Immigration Reform Plan. In: Berkeley La Raza Law Journal. Vol. 15, n. 125, 2004.

MOULIN, C. Eppur si muove: mobilidade humana, cidadania e globalização. Contexto Internacional, v. 33, n. 1, 2011.

MOURA, Márzio. Uma análise atual da situação da capacidade civil e da culpabilidade penal dos silvícolas brasileiros. In: Revista CEJ, 2009.

MOZINE, Augusto César Salomão et. al. Migrações Ambientais e Direitos Humanos: o discurso da mídia de massa e os haitianos na Amazônia. Trabalho apresentado no $\mathbf{7}^{\mathbf{0}}$ Encontro Anual da ANDHEP, 2012.

NUSSBAUM, MARTHA C.. Patriotismo y cosmopolitismo. In: NUSSBAUM, Martha C.. Los límites del patriotismo. Identidad, pertenencia y 'ciudadanía mundial'. Barcelona: Paidós, 1996.

ORGANISATION FOR ECONOMIC COOPERATION AND DEVELOPMENT. International Migration Outlook part III: Immigrant Health Workers in OECD Countries in the Broader Context of Highly Skilled Migration. 2007. Disponível em: http://www.oecd.org. Acesso em 14 mai 2014.

ORGANIZAÇÃO INTERNACIONAL PARA AS MIGRAÇÕES. Perfil Migratório do Brasil 2009. s.1.: OIM, 2010.

ORGANIZAÇÃO INTERNACIONAL DO TRABALHO. Trabalho Decente nas Américas. Uma Agenda Hemisférica. 2006-2015. Informe do Diretor-Geral. Brasil, 2006. 
PAPASTEGIARDIS, Nikos. The Turbulence of Migration: Globalization, Deterritorialization and Hybridity. Cambridge: Polity Press, 2000.

PÉCOUD, A. The UN Convention on Migrant Workers' Rights and international migration management. Global Society, v. 23, n. 3, p. 333-350, 2009.

PÉCOUD, A.; GUCHTENEIRE, P. Migration, Human Rights and the United Nations: An Investigation into the Obstacles to the UN Convention on Migrant Workers' Rights. Windsor YB Access Just., v. 24, p. 241, 2006.

PÉCOUD, A.; GUCHTENEIRE, P. Between Global Governance and Human RightsInternational Migration and the United Nations. Geo. J. Int'I Aff., v. 8, p. 115, 2007.

PÉCOUD, A.; GUCHTENEIRE, P. International migration, border controls and human rights: Assessing the relevance of a right to mobility. In: Journal of Borderlands Studies, vol. 21, n. 1, 2006.

PEIXOTO, José. Tráfico, contrabando e imigração irregular. Os novos contornos da imigração brasileira em Portugal. In: Sociologia, Problemas e Práticas, n. 53, 2007.

PÉCOUD, Antoine; LEVATINO, Antonina. Overcoming the Ethical Dilemmas of Skilled Migration? An analysis of International Narratives on the "Brain Drain". In: American Behavioral Scientist, XX (X), 2012.

PISCITELLI, A. Entre as “máfias” e a “ajuda”. Cadernos Pagu, v. 31, p. 29-63, 2008.

PORTES, Alejandro. Migración y desarrollo: un intento de conciliar perspectivas opuestas. In: Nueva Sociedad, $n^{\circ} 233,2011$.

PÓVOA NETO, Hélion. O erguimento de barreiras à migração e a diferenciação dos "direitos à mobilidade". In: REMHU - Revista Interdisciplinar da Mobilidade Humana. Ano XVI, n. 31, 2008.

PÓVOA NETO, Hélion; SPRANDEL, Marcia Anita. Os objetivos da Conferência Internacional sobre População e Desenvolvimento (Cairo, 1994) e a política migratória brasileira. In: ABEP; UNFPA. Brasil, 15 anos após a Conferência do Cairo. Campinas, 2009. 
PREFEITURA MUNICIPAL DE SÃO PAUlO. $1^{\text {a }}$ Conferência Municipal de Políticas para Migrantes. Secretaria Municipal de Direitos Humanos e Cidadania de São Paulo. Coordenação de Políticas para Migrantes. Documento final disponível em: http://www.prefeitura.sp.gov.br/. Acesso em: 19 mai 2014

PRETURLAN, Renata. Mobilidades e classe sociais: o fluxo migratório boliviano para São Paulo. Dissertação de Mestrado. Programa de Pós-graduação em Sociologia, Faculdade de Filosofia, Letras e Ciências Humanas, Universidade de São Paulo, São Paulo, 2012.

QUAGLIONI, Diego. La sovranità. Bari: Laterza, 2004.

RAMOS, André de Carvalho. Direitos dos Estrangeiros no Brasil: a Imigração, Direito de Ingresso e os Direitos dos Estrangeiros em Situação Irregular. In: SARMENTO, Daniel; IKAWA, Daniela; PIOVESAN, Flávia (Org.). Igualdade, Diferença e Direitos Humanos. Rio de Janeiro: Lumen Juris, 2008.

RAMOS, André de Carvalho; RODRIGUES, Gilberto; ALMEIDA, Guilherme de Assis (Orgs.). 60 Anos de ACNUR: perspectivas de futuro. São Paulo: Editora CL-A Cultural, 2011.

REIS, Rossana Rocha. Políticas de imigração na França e nos Estados Unidos. São Paulo: Hucitec, 2007.

REIS, Rossana Rocha. A política do Brasil para as migrações internacionais. In: Contexto Internacional. Vol. 33, n. 1, 2011.

RIGO, Enrica. Citizens despite borders: challenges to the territorial order of Europe. In: SQUIRE, Vicki. The Contested Politics of Mobility: Borderzones and Irregularity. Routledge, 2011.

RIZEK, Cibele Saliba; GEORGES, Isabel; FREIRE DA SILVA, Carlos. Trabalho e imigração: uma comparação Brasil-Argentina. In: Lua Nova, n. 79, 2010.

RUHS, Martin. The potential of temporary migration programmes in future international migration policy. Paper prepared for the Policy Analysis and Research Programme of the Global Commission on International Migration, 2005.

RUHS, Martin. Openness, Skills and Rights: An empirical analysis of labour immigration programmes in 46 high- and middle- income countries. In: COMPAS. Working Paper, n. 88. University of Oxford, 2011. 
RUHS, Martin; MARTIN, Philip. Numbers vs. Rights: Trade-Offs and Guest Worker Programs. In: International Migration Review, vol. 42, n. 1, 2008.

SANTOS, Boaventura de Sousa. Pela mão de Alice. O social e o político na pósmodernidade. Coimbra: Almedina, 2013.

SASSEN, Saskia. Globalization and Its Discontents: Essays on the New Mobility of People and Money. New York: New Press, 1998.

SASSEN, Saskia. Territory, authority, rights. From Medieval to Global Assemblages. Princeton: Princeton University Press, 2006.

SAYAD, Abdelmalek. La double absence. Des illusions de l'émigré aux souffrances de l'immigré. Paris: Seuil, 1999.

SCARIOT, Eléia. Esteriótipos da migração produzidos pelo discurso da mídia impressa nacional. s.l, s.d.

SCHILLING, Flavia. A sociologia na modernidade radical: quem tem medo da incerteza? In: Revista USP, São Paulo, n.54, 2002.

SCHILLING, Flavia. Ética, promessas. In: Coloquio do LEPSI IP/FE-USP, 3, São Paulo, 2001.

SECRETARIA DE ASSUNTOS ESTRATÉGICOS. Política Migratória Brasileira: produção e desenvolvimento. S.d. Disponível em: http://www.sae.gov.br/. Acesso em 15 mai 2014.

SERIKAWA, Leonardo Kazuo dos Santos. Acreditação e qualidade da educação superior: abrindo a caixa-preta do sistema de acreditação de cursos superiores do Mercosul. Dissertação de Mestrado. Brasília: Universidade de Brasília, 2013.

SEYFERTH, Giralda. As identidades dos imigrantes e o melting pot nacional. In: Horizontes Antropológicos, Porto Alegre, ano 6, n. 14, 2000.

SEYFERTH, Giralda. Colonização, imigração e a questão racial no Brasil. In: Revista USP, n. $52,2002$. 
SILVA, José Afonso. Curso de Direito Constitucional Positivo. $25^{\text {a }}$ ed. São Paulo: Malheiros, 2005.

SILVA, Sidney Antonio. Bolivianos em São Paulo: entre o sonho e a realidade. In: Estudos Avançados, vol. 20, n. 57, 2006.

SILVA, Sidney Antonio. Hispânico ou Latino. Faces de um processo identitário entre imigrantes sul-americanos em São Paulo. In: Odair da Cruz Paiva (Org.). Migrações Internacionais: desafios para o século XXI. São Paulo: Memorial do Imigrante, v.1, 2007.

SILVA, Luís Inácio Lula da. Discurso do Presidente da República, Luiz Inácio Lula da Silva, durante cerimônia de sanção da lei que anistia estrangeiros em situação irregular no Brasil. Brasília: Ministério da Justiça. 02 de julho de 2009. Disponível em: http://www.biblioteca.presidencia.gov.br/. Acesso em: 15 mai 2014.

SOUZA, Wlaumir Doniseti. Anarquismo, Estado e pastoral do imigrante. Das disputas ideológicas pelo imigrante aos limites da ordem: o Caso Idalina. São Paulo: Editora UNESP, 2000 .

SQUIRE, Vicki. The contested politics of mobility: Politicizing mobility, mobilizing politics. In: In: SQUIRE, Vicki. The Contested Politics of Mobility: Borderzones and Irregularity. London: Routledge, 2011.

STATHAM, Paul; GEDDES, Andrew. Elites and the 'Organised Public': Who Drives British Immigration Politics and in Which Direction. In: West European Politics. Vol. 29 n. 2, 2006.

TELES, Edson. Ação Política em Hannah Arendt. São Paulo: Editora Barcarolla, 2013.

THE BINATIONAL Migration Institute. A Continued Humanitarian Crisis at the Border. Undocumented border crosser deaths recorded by the Pima County Office of the Medical Examiner, 1990-2012. The University of Arizona, June 2013.

TORRES, Ana Paulo Repolês. O Sentido da Política em Hannah Arendt. In: Trans/Form/Ação, São Paulo, vol. 30 n. 2, 2007.

TRIGGIANI, Ennio. La cittadinanza europea per la "utopia" sovranazionale. In: Studi sull'integrazione europea. Numero 3, 2006. 
TYNER, James A. The Global Context of Gendered Labor Migration From the Philippines to the United States. In: American Behavioral Scientist, vol. 42, n.4, 1999.

UNASUL. Declaración de la Unión de Naciones Suramericanas sobre la "Directiva de Retorno" de la Unión Europea. 04 jul 2008. Disponível em: http://www.comunidadandina.org/unasur/4-7-08directivaUE.htm. Acesso em 30 jun 2013.

UNICEF. Situation générale en Haiti. Disponível em: http://www.unicef.org/haiti/french/overview_8833.htm. Acesso em: 4 mai 2014.

UNHCR. A Year of Crisis. Global Trends, 2011.

VAN DER KLAAUW, Johannes. Refugee Rights in Times of Mixed Migration: Evolving Status and Protection Issues. In: Refugee Survey Quarterly. Vol. 28, n. 4, 2009.

VAN HEAR, Nicholas; BRUBAKER, Rebecca; BESSA, Thais. Managing mobility for human development: the growing salience of mixed migration. In: PNUD. Human Development Research Paper (HDRP) Series. Vol. 20, 2009;

VATICANO. Pontifício Conselho da Pastoral para os Migrantes e os Itinerantes. Instrução "A Caridade de Cristo para com os Migrantes", s.d. Disponível em: http://www.vatican.va/roman_curia/pontifical_councils/migrants/documents/rc pc migrants doc_20040514_erga-migrantes-caritas-christi_po.html\#APRESENTAÇÃO. Acesso em 14 mai 2014.

VENTURA, Deisy; ILLES, Paulo. Qual a política migratória do Brasil. In: Le Monde Diplomatique Brasil, 07 mar 2012. Disponível em: http://www.diplomatique.org.br/artigo.php?id=1121. Consulta em 10 mai 2014.

VENTURA, Deisy; BARALDI, Camila. A UNASUL e a Nova Gramática da Integração Sul-americana. In: Pontes, vol. 4, nº 3, 2008.

VERTOVEC, Steven. Transnationalism and Modes of Transformation. In: International Migration Review, vol. 38, $\mathrm{n}^{\mathrm{o}}$ 3, Conceptual and methodological developments in the Study of International Migration, 2004.

VERTOVEC, Steven. Circular Migration: the way forward in global policy? In: IMI Working papers. Paper 4, 2007. 
WIHTOL DE WENDEN, Catherine. La question migratoire au XXIe siècle. 2nd éd. revue et augmentée. Paris: Presses de Sciences Po, 2013.

WIHTOL DE WENDEN, Catherine. La Globalisation des migrations. Mondialisation des migrations et droit à la mobilité. In: Fondation Memoire Albert Cohen. E-colloque. s.d. Disponível em: http://ecolloque.fondationmemoirealbertcohen.org/index.php?page=globalisationdesmigration s. Acesso em: 10 mai 2014.

WIMMER, Andreas; GLICK SCHILLER, Nina. Methodological Nationalism, the Social Sciences, and the Study of Migration: An Essay in Historical Epistemology. In: International Migration Review. Volume 37, n. 3, 2003.

ZANFORLIN, Sofia Cavalcanti et. al. MídiaMigra: Observatório de Comunicação e Migração Contemporânea no Brasil. In: Razón y Palabra, n. 86, 2014.

Legislação, pareceres, jurispridência e declarações

ASSEMBlÉia legislativa do ESTAdo DE SÃO PAUlO. Ato do Presidente $\mathbf{n}^{\mathbf{0}} \mathbf{7}$ de 07 mar 2014.

ARGENTINA. Ley 25.871 de 2004. Ley de Migraciones.

CORTE INTERAMERICANA DE DERECHOS HUMANOS (CIDH). Caso Vélez Loor vs. Panamá. Sentencia de 23 de noviembre de 2010. Disponível em: http://www.corteidh.or.cr/docs/casos/articulos/seriec_218_esp.pdf. Acesso em: 15 mai 2014.

BRASIL. Lei Delegada n ${ }^{\circ} 11$ de 11 de outubro de 1962.

BRASIL. Lei 4.505 de 30 de novembro de 1964 - Estatuto da Terra.

BRASIL. Lei 6815 de 19 de agosto de 1980.

BRASIL. Código Civil, 1916.

BRASIL. Código Civil, 2002. 
BRASIL. Conselho Nacional de Imigração (CNIg). Resolução n. 97 de 12 de janeiro de 2012.

BRASIL. Conselho Nacional de Imigração (CNIg). Resolução n. 102 de 26 de abril de 2013.

BRASIL. MSC 696/2010.

BRASIL. Decreto nº 19.770, de 19 de Março de 1931. Lei de Sindicalização.

BRASIL. Consolidação das Lei do Trabalho 1943.

BRASIL. Decreto-Lei 7967 de 1945. $2^{\circ}$ Estatuto do Estrangeiro.

BRASIL. Constituição de 1946.

BRASIL. Constituição de 1967 e Emenda de 1969.

BRASIL. PL 3637/2008 - Altera a Lei $n^{0}$ 6.815, de 19 de agosto de 1980, para permitir a concessão de visto a estrangeiro portador de documento de viagem emitido por governo não reconhecido pelo Brasil

BRASIL. PL 1499/2007 - Estabelece a concessão de visto temporário para os estrangeiros que vierem trabalhar temporariamente em eventos esportivos de nível internacional.

BRASIL. PL 3059/2008 recentemente transformado na Lei Ordinária 12968/2014, altera o Estatuto do Estrangeiro, visando a criação de procedimento alternativo para a obtenção de visto de turista.

BRASIL. PL 3772/2008 transformado na Lei 12878/2013, altera a Lei $\mathrm{n}^{\circ} 6.815$, de 19 de agosto de 1980, oferecendo nova disciplina à prisão preventiva para fins de extradição

BRASIL. Decreto 6964 de 29 de setembro de 2009. Incorporação do Acordo sobre Residência para Nacionais dos Estados membros do Mercosul.

BRASIL. Decreto 6975 de 07 de outubro de 2009. Incorporação do Acordo sobre Residência para Nacionais dos Estados membros do Mercosul.

MINISTÉRIO DA JUSTIÇA. Portaria n. 103 do Ministro de Estado da Justiça de 29 de maio 
de 2013, publicada no DO em 31 de maio de 2013

CÂMARA DOS DEPUTADOS, Parecer na Comissão De Relações Exteriores e Defesa Nacional sobre o Projeto de Lei 1664 de 2007, 03 out 2007.

CÂMARA DOS DEPUTADOS, Parecer na Comissão de Constituição e Justiça sobre o Projeto de Lei 1664 de 2007, 18 jun 2008

CÂMARA DOS DEPUTADOS, Parecer em Plenário pela Comissão de Constituição e Justiça sobre o Projeto de Lei 1664 de 2007, 18 fev 2009.

ESTADO DE SÃO PAULO. Resolução n. 10 de 1995 da Secretaria Estadual de Educação.

ESPANA. Ley Orgánica 4/2000.

ESPANA. Ley Orgánica 2/2009.

FÓRUM SOCIAL MUNDIAL DAS MIGRAÇÕES. Declaração Final do $5^{0}$ Fórum, Filipinas, 2012. Disponível em: http://www.wsfm2012.org/. Acesso em: 14 mai 2014.

FÓRUM SOCIAL MUNDIAL DAS MIGRAÇÕES. Declaração Final do $4^{0}$ Fórum, Quito, $2010 . \quad$ Disponível em: http://www.gritodelosexcluidos.org/media/uploads/declaracionivfsmm2010final.pdf. Acesso em: 14 mai 2014.

FRANCE. Conseil d'État. Arrêt No 332363 de 2012.

IPPDH. Solicitação de uma Opinião Consultiva sobre crianças migrantes perante a Corte Interamericana de Direitos Humanos. Disponível em: http://www.corteidh.or.cr. Acesso em 14 mai 2014.

ITALIA. Legge n. 129 del 02 agosto 2011.

ITALIA. Legge 67/14 del 28 aprile 2014. 
República do Chile. assinado em 15 de dezembro de 2000 e promulgado no Brasil pelo Decreto n. 5852 de 2006.

MERCOSUL. Acordo com a Argentina prevê a Concessão de Permanência a Detentores de Vistos Temporários ou a Turistas. Celebrado em Puerto Iguazú, em 30 de novembro de 2005 e promulgado no Brasil pelo Decreto 6736 de 12 de janeiro de 2009.

MERCOSUL. Decisão CMC 64/2010.

MERCOSUL. Decisão CMC 65/2010.

MERCOSUL. Decisão CMC 12/2011.

MINISTÉRIO DE RELAÇÕES EXTERIORES. Nota no 88 de 15 de Agosto de 2005. Publicada no DOU nº. 179, de 16/09/2005, Seção 1 página 67.

ORGANIZAÇÃO DAS NAÇÕES UNIDAS. Convenção das Nações Unidas relativa ao Estatuto dos Refugiados de 1951.

ORGANIZAÇÃO DAS NAÇÕES UNIDAS. Convenção das Nações Unidas sobre Todos os Trabalhadores Migrantes e Membros de Suas Famílias de 1990.

ORGANIZAÇÃO DAS NAÇÕES UNIDAS. Convenção das Nações Unidas contra o Crime Organizado Transnacional Relativo à Prevenção, Repressão e Punição do Tráfico de Pessoas, em Especial Mulheres e Crianças de 2000.

ORGANIZAÇÃO DAS NAÇÕES UNIDAS. Protocolo Adicional à Convenção das Nações Unidas contra o Crime Organizado Transnacional Relativo à Prevenção, Repressão e Punição do Tráfico de Pessoas, em Especial Mulheres e Crianças de 2000.

ORGANIZAÇÃO DAS NAÇÕES UNIDAS. Declaração das Nações Unidas sobre os Direitos Humanos dos Indivíduos que não são Nacionais do País onde Vivem (A/RES/40/144, adotada pela Assembléia Geral em 13 de dezembro de 1985). Disponível em: http://www.un.org/documents/ga/res/40/a40r144.htm. Acesso em: 14 mai 2014.

ORGANIZAÇÃO DAS NAÇÕES UNIDAS. Resolução da AG n. 53/11 de 9 de dezembro de 1998.

ORGANIZAÇÃO DAS NAÇÕES UNIDAS. Resolução 3224 de 6 de novembro de 1974. 
ORGANIZAÇÃO DAS NAÇÕES UNIDAS. Resolução 3449 de 9 de dezembro de 1975.

ORGANIZAÇÃO DAS NAÇÕES UNIDAS. Resolução 127 de 16 de dezembro de 1976.

PREFEITURA MUNICIPAL DE SÃO PAULO. Parecer do Conselho Municipal de Educação (CME) n 17/04 - Aprovado em 27 maio 04 - EMEF Infante Dom Henrique: alunos estrangeiros de ensino fundamental sem Registro Nacional de Estrangeiro (RNE). Disponível em: http://www.prefeitura.sp.gov.br. Acesso em: 12 dez 2013

UNIÃO EUROPEIA. Conclusões do Conselho Europeu de 18 e 19 de junho de 2009.

UNIÃO EUROPEIA. Conselho Europeu. Programa de Estocolmo. Uma Europa aberta e segura que sirva e proteja os cidadãos. 2010/C 115/1.

UNIÃO EUROPEIA. Directiva 2008/115/CE do Parlamento Europeu e do Conselho. 16 de Dezembro de 2008 relativa a normas e procedimentos comuns nos Estados-Membros para o regresso de nacionais de países terceiros em situação irregular.

UNIÃO EUROPEIA. Global Approach to Migration and Mobility (GAMM), 2005.

UNIÃO EUROPEIA. COM (2011) 743. segunda fase das diretrizes de trabalho para o tratamento das migrações em suas relações com países terceiros, 2011.

UNITED STATES. Trafficking Victims Protection Act (TVPA), 2000, 2003, 2005, 2008. Disponível em: http://www.state.gov/j/tip/laws

UNITED STATES. Trafficking in Persons Report (TIP Report). Anual. Disponível em: http://www.state.gov/j/tip/laws

URUGUAY. Ley 18.250 de 2008.

SENADO FEDERAL. Parecer $\mathbf{n}^{\mathbf{0}}$ 286, 18 mar 2004 sobre o Projeto de Decreto Legislativo $n^{\circ} 943$ de 2003.

SENADO FEDERAL. PLS 399/2011. Projeto de lei que simplifica a revalidação de diplomas de cursos presenciais de graduação, mestrado e doutorado expedidos por instituições de 
educação superior estrangeiras de excelência reconhecida pelo poder público brasileiro.

SUPREMO TRIBUNAL FEDERAL. ADI 5035.

SUPREMO TRIBUNAL FEDERAL. ADI 5037.

Notícias

ADUC. Associazione per i diritti degli utenti e consumatori. Immigrazione, depenalizzazione del reato di immigrazione clandestina. Disponível em: http://www.aduc.it/articolo/immigrazione+depenalizzazione+reato+immigrazione_22139.php. Acesso em 10 mai 2014.

ANDRADE, Almir. Governo do Acre vai acabar com abrigo dos imigrantes em Brasileia. Notícias da Fronteira, 08 abr 2014. Disponível em: http://www.noticiasdafronteira.com.br/2014/04/08/governo-do-acre-vai-acabar-com-abrigodos-imigrantes-em-brasileia/. Acesso em: 15 mai 2014

CABRAL, Otávio. Milícia Refugiada. In: Revista VEJA. Coluna Holofote. Edição de 14 de maio de 2014

CONECTAS. Brasil esconde emergência humanitária no Acre, 12 ago 2013. Disponível em: http://www.conectas.org/pt/acoes/politica-externa/noticia/brasil-esconde-emergenciahumanitaria-no-acre. Acesso em: 4 mai 2014.

CONECTAS. Governo fecha abrigo para haitianos em Brasileia, 09 abr 2014. Disponível em: http://www.conectas.org/pt/acoes/politica-externa/noticia/17008-governo-fecha-abrigopara-haitianos-em-brasileia. Acesso em 04 mai 2014.

CRUZ, Fernanda. Prefeitura de São Paulo cria abrigo para receber haitianos. Agência Brasil, 05 mai 2014. Disponível em: http://agenciabrasil.ebc.com.br/direitos-humanos/noticia/201405/prefeitura-de-sao-paulo-cria-abrigo-para-receber-haitianos. Acesso em 06 mai 2014.

ÉBOLI, Evandro. Resolução regulamentando a presença de haitianos é aprovada. O Globo, 12 jan 2012.

FARIAS, Adriana, CIOFFI, Silvio. Burocracia deixa estrangeiros em busca de refúgio no limbo jurídico. Folha de S. Paulo, 26 abr 2014. Disponível em: http://www1.folha.uol.com.br/mundo/2014/04/1445920-burocracia-deixa-estrangeiros-em- 
busca-de-refugio-no-limbo-juridico.shtml. Acesso em: 09 mai 2014.

GIRALDI, Renata. Em cinco anos, pelo menos 300 mil brasileiros que viviam no exterior retornaram ao Brasil. Agência Brasil, 27 mar 2013.

GOVERNO Brasileiro anuncia concessão de residência para 4.482 estrangeiros. Agência Brasil, 19 dez 2013. Disponível em: http://memoria.ebc.com.br/agenciabrasil/noticia/201312-19/governo-brasileiro-anuncia-concessao-de-residencia-para-4482-estrangeiros. Acesso em: 19 mai 2014.

HAITIANOS afirma estarem sendo vítimas de preconceito em Cascavel. Terra Notícias, em 27 fev 2014a. Disponível em: http://noticias.terra.com.br/brasil/catve/videos/haitianosafirmam-estarem-sendo-vitimas-de-preconceito-em-cascavel,7337971.html\&novo_portal=1. Acesso em: 15 mai 2014.

HAITIANOS vítimas de ameaças temem ficar sem moradia. Terra Notícias, em 28 fev 2014b. Disponível em: http://noticias.terra.com.br/brasil/catve/videos/haitianos-vitimas-deameacas-temem-ficar-sem-moradia,7339821.html\&novo_portal=. Acesso em: 15 mai 2014.

IMIGRANTES expõem suas reivindicações em Audiência na Câmara Municipal. In: Centro de Direitos Humanos e Cidadania do Imigrante (CDHIC), 30 ago 2013. Disponível em: http://www.cdhic.org.br/?p=1315. Acesso em 14 mai 2014.

MANTOVANI, Flávia. Árabes de SP ajudam refugiados sírios em 'via-crúcis' da adaptação. G1 São Paulo, 22 mar 2014. Disponível em: http://g1.globo.com/saopaulo/noticia/2014/03/arabes-de-sp-ajudam-refugiados-sirios-em-crucis-da-adaptacao.html. Acesso em: 09 mai 2014.

THOMAZ, Omar Ribeiro. Fronteira social e fronteira de serviço. O Estado de S. Paulo, 28 jan. 2012. Disponível em: http:/www.estadao.com.br/noticias/suplementos, fronteira-social-efronteira-de-servico,828430,0.htm. Acesso em: 10 mai 2014.

MACHADO, Altino. Migração em massa de haitianos deixa Brasiléia, no Acre, em 'situação de colapso'. Terra Magazine, 04 jan 2012. Disponível em: http://terramagazine.terra.com.br/blogdaamazonia/blog//2012/01/04/migracao-em-massa-dehaitianos-deixa-brasileia-no-acre-em-situacao-de-colapso/. Acesso em 04 mai 2014.

MELLO, Patricia Campos; CARNEIRO, Mariana. Brasil prepara plano para ampliar mão de obra estrangeira. In: Folha de São Paulo, edição de 30 dez 2012a. Disponível em: http://www1.folha.uol.com.br/mercado/2012/12/1207957-brasil-prepara-plano-para-ampliarmao-de-obra-estrangeira.shtml. Acesso em: 15 mai 2014. 
MELLO, Patricia Campos; CARNEIRO, Mariana. http://www1.folha.uol.com.br/mercado/1207961-visto-de-trabalho-para-estrangeiros-nobrasil-demora-quase-2-meses.shtml. In: Folha de São Paulo, edição de 30 dez 2012b. Acesso em: 14 mai 2013.

MILESI, Rosita. Brasil e os desafios da lei de migrações. Entrevista especial com Rosita Milesi. IHU Online, 18 jan 2012. http://www.ihu.unisinos.br/entrevistas/505828entrevista-especial-com-rosita-milesi-

NEL CANALE di Sicilia 7.065 tra morti e dispersi dal 1994. Fortress Europe, 03 oct. 2013. Disponível em: http://fortresseurope.blogspot.com.br/2006/02/nel-canale-di-sicilia.html. Acesso em: 11 mai 2014.

ORGANIZAÇÃO INTERNACIONAL PARA AS MIGRAÇÕES. Haitian migrants, desperate for survival, find death on high seas. $06 \mathrm{dez} 2013$.

Disponível em: https:/www.iom.int/cms/en/sites/iom/home/news-and-views/press-briefingnotes/pbn-2013/pbn-listing/haitian-migrants-desperate-for-s.html

OTAVIO, Chico; GUILAYN, Priscila. Brasil quer facilitar vistos para profissionais estrangeiros. In: O Globo, edição de 15 jan 2012. Disponível em: http://oglobo.globo.com/pais/brasil-quer-facilitar-vistos-para-profissionais-estrangeiros3671799. Acesso em: 15 mai 2013.

PANORAMA. L'immigrazione clandestina non è più reato. $\mathbf{E}$ ora? Disponível em: http://news.panorama.it/politica/abolizione-reato-immigrazione-clandestina. Consulta em: 10 mai 2014.

PYL, Bianca. Imigrantes reclamam de entraves criados durante a Anistia. In: Repórter Brasil, 09 dez 2011. Disponível em: http://reporterbrasil.org.br/2011/12/imigrantes-reclamamde-entraves-criados-durante-a-anistia/. Acesso em: 15 mai 2014.

QUATRO anos após terremoto no Haiti, $90 \%$ dos desabrigados já voltaram para casa. Opera Mundi, 12 jan 2014. Disponível em: http://operamundi.uol.com.br/conteudo/noticias/33406/quatro+anos+apos+terremoto + no + hait $\mathrm{i}+90 \% 25+$ dos + desabrigados $+\mathrm{ja}+$ voltaram + para + casa.shtml

RESENDE, Thiago. Comissão estuda mudanças nas regras do visto de trabalho para Estrangeiros. Valor Econômico, 13 fev 2013. 
RIBEIRO, Bruno. Acre "deporta" para São Paulo 400 refugiados do Haiti. O Estado de S. Paulo, 23 abr 2014. Disponível em: http://sao-paulo.estadao.com.br/noticias/geral,acredeporta-para-sao-paulo-400-refugiados-do-haiti,1157704. Acesso em: 04 mai 2014.

RIBEIRO, Bruno. Haitianos recebem colchões e marmitas em abrigo de São Paulo. O Estado de S. Paulo, 25 abr 2014. Disponível em: http://saopaulo.estadao.com.br/noticias/geral,haitianos-recebem-colchoes-e-marmitas-em-abrigo-desao-paulo,1158640. Acesso em: 04 mai 2014.

SANT'ANNA, Emilio. Após quase um mês em São Paulo, haitianos vindos do AC vão para abrigo. Folha de São Paulo, edição de 09 mai 2014. Disponível em: http://www1.folha.uol.com.br/cotidiano/2014/05/1451724-apos-quase-um-mes-em-sphaitianos-vindos-do-ac-vao-para-abrigo.shtml. Acesso em: 15 mai 2014.

Sites consultados

http://www.ilo.org

http://www.iom.int/

https://treaties.un.org

http://fortresseurope.blogspot.com.br

http://www.camara.gov.br.

http://www.ippdh.mercosur.int

http://www.noborder.org/

http://www.brasil.iom.int

operamundi.uol.com.br

portal.mte.gov.br

reporterbrasil.org.br

www.prefeitura.sp.gov.br 